\title{
VOKIEČIỤ SAUGUMO POLICIJOS IR SAUGUMO TARNYBOS (SD) VADO INSTITUCIJA LIETUVOS GENERALINĖJE SRITYJE 1941-1944 METAIS
}

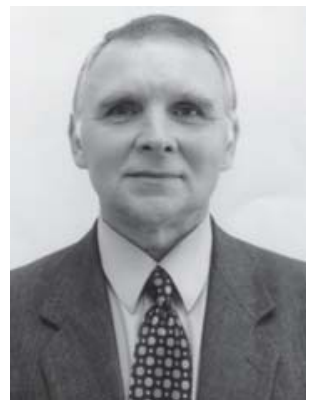

\author{
Dr. Petras STANKERAS
}

\section{Istoriografija}

Šia studija autorius toliau gvildena vokiečiuc policijos struktūrų buvimą Lietuvos generalineje srityje paskutinio pasaulinio karo XX a. metais ${ }^{1}$. Iki šiol ịvairių autorių parašyti darbai, kuriuose tiesiogiai arba netiesiogiai būtų aptariami karo metu vokiečių saugumo policijos ir saugumo tarnybos vado institucijos įsteigimo bei struktūrizavimo Lietuvos generalinèje srityje klausimai, yra gana kuklūs. Apie šią instituciją, jos padalinių genezę, struktūrą, organizacinius pasikeitimus, kadrų kaitą bei funkcijas, veiklą Lietuvoje Antrojo pasaulinio karo metais kol kas nèra atskiros išsamios istorinės monografijos, - yra tik atskiri skyriai kai kuriose knygose bei keli straipsniai ivvairiuose periodiniuose leidiniuose.

Svarbiausias informacijos šaltinis istoriniams tyrimams yra archyvai. Gausi archyvinė medžiaga, kurioje yra nemaža duomenu apie vokiečių institucijų veiklą Pabaltijyje Antrojo pasaulinio karo metais, taip pat ir Lietuvoje, karo metu pateko JAV armijai ir buvo išgabenta i Ameriką, i Aleksandrijos miestą netoli Vašingtono. Nemaža dalis medžiagos pateko ị JAV Kongreso biblioteką, Huverio biblioteką ir kitur. Itin svarbus mums yra vyresnio-

\footnotetext{
1 Pirmoji studija - P. Stankeras, „Aukščiausioji vokiečių SS ir policijos vadovybė Lietuvos generalinèje srityje 1941 - 1944 metais“, Genocidas ir rezistencija, 2001, Nr.2 (10), p. 17 - 30.
} 
jo vokiečių saugumo policijos ir SD vado Rygoje fondas, kuris, deja, yra saugomas Istorinių - dokumentinių kolekcijų saugojimo centre Maskvoje ${ }^{2}$. Likę Lietuvoje didžiausi ir pagrindiniai archyvinių dokumentų klodai nagrinejjama tema yra sukaupti Lietuvos centriniame valstybès archyve (toliau - LCVA). Čia saugomi vokiečių valdžios išleisti dokumentai sovietmečiu buvo prieinami nedaugeliui - tik patikimiems istorikams ir KGB žinybų darbuotojams, nes buvo ịtraukti ị slaptų fondų sąrašus. Dabar, kai dauguma fondų yra išslaptinta, ypač daug vertingų dokumentų bei ịvairios informacijos rasta šio archyvo Lietuvių kriminalinès policijos skyriaus prie saugumo policijos ir SD vado (f. R-1216), saugumo policijos ir SD vado Lietuvoje Lietuviškajame Panevėžio skyriuje (f. R-650), Lietuvos generalinès srities vokiečių saugumo policijos ir SD vado Lietuvoje (f. R-972 ir f. R-1399) ir kituose fonduose. Fonde R-1399 yra 126 saugojimo vienetai. Čia randame įvairius direktyvinius vokiečių vyresniojo vokiečių saugumo policijos ir SD vado Ostlande nurodymus, vokiečiu saugumo policijos ir SD vado Lietuvos generalinėje srityje kasmėnesines ataskaitas Vyriausiajai Reicho saugumo valdybai, susirašinėjimą apie sovietinių partizanų veiklą bei gyventojų sabotažą įmonèse, susirašinėjimą apie lietuvių pogrindị, apie suemmimus, tardymo bylas, statistinius duomenis apie suimtuosius, mėnesines ataskaitas apie gyventojų nuotaikas, susirašinejjimą su lietuvių saugumo policija, su lietuvių policijos batalionų vadovybe apie bendras akcijas prieš bolševikų partizanus, informaciją apie Kaune įsteigtą aukštesniają vokiečių mokyklą, kurioje buvo numatyta rengti vadų korpusą Rytams ir konkrečiai Lietuvai valdyti ir kt. Rytų frontui grižtant ị Lietuvos teritoriją, vokiečių saugumo policijos padaliniai, jei nespejjo išvežti ị Vokietiją, tai spėjo sunaikinti savo pačių sukauptą archyvą, to meto dokumentus, kartotekas ir kitą medžiagą. Be to, nemažai vertingų dokumentų sudegè arba buvo sunaikinta mūšių metu, ypač Vilniaus tvirtovès gynybos metu.

Saugumo policijos ir SD operatyvinių grupių veiklą užimtose priešo teritorijose aptaria vokiečių dokumentai, paskelbti tarptautinio Niurnbergo proceso dokumentų rinkiniuose. Čia randame garsią dr. F. V. Štalekerio (F. V. Stahlecker) $1941 \mathrm{~m}$. spalio 15 d. ataskaitą (dokumentas L-180)³, kurią reikètų vertinti kritiškai, bei to paties autoriaus priešmirtinès ataskaitos juodraštị be tikslios datos (1942 m. vasaris - kovas) (Tarptautinio Niurnbergo proceso dokumentas PS-2273).

\footnotetext{
${ }^{2}$ S. Jegelevičius, „Ypatingasis archyvas Maskvoje“, Lietuvos istorijos studijos, t. 3, 1996, p. 144.

${ }^{3}$ Нюрнбергский процесс, Москва, 1966, том 3, с. 321-335.
} 
Vos ne pirmą kartą istorineje literatūroje lietuvių kalba abreviatūrą „SD“ randame $1946 \mathrm{~m}$. birželio $19 \mathrm{~d}$. pasirašytoje spausdinti ir Valstybinès politinės literatūros leidyklos masiniu tiražu (net 10200 egz.!) išleistoje 79 puslapių knygelèje „Kaltinamoji išvada ir nuosprendis byloje dėl vokiškujų fašistiniu grobikų piktadarybių Latvijos, Lietuvos ir Estijos TSR teritorijoje“" ${ }^{\text {" Čia }}$ „SS“, „SD“, gestapas, ịvairūs komendantai, gebitskomisarai ịvardijami kaip „karinè vokiečių valdžia ir baudžiamieji organai“, kitoje vietoje minima „SD“ kariuomene““ (p. 24). Jokio iššifravimo, ką reiškia „SD“, o tuo labiau informacijos apie minètų institucijų struktūras, funkcijas, vadovus nepateikiama.

1957 m. dienos šviesą išvydo Valstybinès politinès ir mokslinès literatūros leidyklos 7000 egzempliorių tiražu išspausdintas leidinys gana ilgu pavadinimu: „Ypatingosios valstybinès komisijos vokiškujų fašistinių grobikų bei jų bendrininkų piktadarybėms nustatyti ir ištirti pranešimas apie hitlerinių grobikų nusikaltimus Lietuvos Tarybų Socialistineje Respublikoje“" . Nedidelès (tik 24 puslapiai) brošiūros paskutiniame skyrelyje „Pogromininkai ir taikių gyventojų bei tarybinių karo belaisvių žudikai turi stoti ị tarybinès liaudies teismą“ yra pateiktos 127 pavardès (deja, dauguma iškreiptos) tų, kuriuos Ypatingoji valstybinè komisija pripažino „baisingų nusikaltimų $\langle\ldots\rangle$ kaltininkais“. Tačiau šiame nemažame sąraše yra tik vienas vokiečių saugumo policijos pareigūnas - „Lietuvos saugumo policijos ir SD vadas oberfiureris daktaras Fuksas" (turètų būti F u c h s - P. S.). Tačiau dèl neaiškių priežasčių į ši sąrašą nepateko F. V. Štalekerio, K. Jegerio (K. Jäger), H. Biomès (H. Böhme) ir kitų vokiečių saugumo policijos aukštų pareigūnų, gana aktyviai veikusių karo metais Lietuvos generalinès srities teritorijoje, pavardès.

Tais pačiais metais bei tos pačios leidyklos išleistame dokumentiniame propagandiniame leidinyje „Hitlerininku piktadarybès Pabaltijyje" ${ }^{\text {"6 }}$ be papildomų paaiškinimų bei komentarų paminèta abreviatūra „SD“, „SD“ kariuomenè.

Kai kurie leidiniai, kaip dviem kalbomis išleista monografija „Hitleriné okupacija Lietuvoje“"7, balansuoja tarp moksliškumo ir propagandos. Tokio

\footnotetext{
${ }^{4}$ Kaltinamoji išvada ir nuosprendis byloje dèl vokiškụjų fašistinių grobikų piktadarybių Latvijos, Lietuvos ir Estijos TSR teritorijoje, Valstybiné politinès literatūros leidykla, 1946.

5 Ypatingosios valstybinès komisijos vokiškuju fašistinių grobikų bei jų bendrininkų piktadarybėms nustatyti ir ištirti pranešimas apie hitlerinių grobikų nusikaltimus Lietuvos Tarybų Socialistineje Respublikoje, Vilnius, 1957.

${ }^{6}$ Hitlerininku piktadarybès Pabaltijyje, Vilnius, 1957.

${ }^{7}$ Hitlerinė okupacija Lietuvoje, Vilnius, 1961. Гитлеровская оккупация в Литве, Вильнюс, 1966.
} 
pobūdžio leidiniuose maža vilties rasti įdomios ir vertingos medžiagos nagrinejjamai temai, tačiau ir ị juos verta atkreipti kritinị dėmesį. Šiame propagandinių straipsnių rinkinyje J. Paleckis mini „brigadefiurerį Štalenerą“ (p. 12). Kitas autorius P. Kežinaitis rašo apie „Kauno miesto gestapo viršininką Jegerį““ (p. 72) ir apie neegzistuojantị „SS brigadefiurerį Štachlingą“ (p. 90). Straipsnelio pabaigoje autorius parodo savo nekompetenciją nagrinejjamu klausimu pateikdamas abreviatūrą RSHA kaip Vyriausiają rasinés politikos ir įkurdinimo reikalų valdybą vietoje Vyriausiosios Reicho saugumo valdybos (p. 155).

Teisininkas Andrius Bulota, supažindindamas sovietų Lietuvos skaitytojus „su buržuazinių nacionalistų siekimais, su lietuviškųų fašistų parsidavėliška veikla ir tos veiklos metodais praeityje“, lygiagrečiai prabėgom pamini ir H. Himlerio (H. Himmler) vadovaujamą Saugumo tarnybą (Sicherheitsdienst des Reichsfuhrers SS, trumpai vadinama SD) ${ }^{8}$.

1965 m. išspausdinta dokumentų rinkinio „Masinès žudynès Lietuvoje“ I dalis ${ }^{9}$. Tik po $8 \mathrm{~m}$. išleista šio rinkinio antroji dalis ${ }^{10}$. Rinkiniuose apstu nagrinejjamai temai vertingų dokumentų vertimų ir jų fotokopijų. Pirmoje dalyje pateikiama garsioji vokiečiu saugumo policijos ir SD vado Lietuvos generalinèje srityje bei 3-ojo operatyvinio būrio vadovo SS štandartenfiurerio Karlo Jegerio ataskaita Vyriausiajai Reicho saugumo valdybai (Reichssicherheitshauptamt, toliau - RSHA) Berlyne apie nuveiktą darbą jo valdomoje teritorijoje. Ją reikètų vertinti kritiškai ir ne viskuo, kas yra parašyta karjeros siekiančio pavaldinio savo viršininkams Berlyne, tikèti. Rinkinio pirmos dalies komentaruose trumpai apibūdinama vokiečių saugumo policijos bei jos operatyvinès grupés A struktūra bei funkcijos. Dokumentų rinkinio antroje dalyje (psl. 17 - 22) pateikto SS brigadefiurerio ir policijos gen. mjr. teisès dr. F. V. Štalekerio $1941 \mathrm{~m}$. spalio 15 d. raporto ${ }^{11}$ (Niurnbergo proceso dokumentas L-180) skaičius aptarè netgi SS gen. O. Olendorfas (O. Ohlendorf) (operatyvinès grupès „D“ vadas - P. S.), teigdamas, kad jie gerokai didesni, siekiant ịtikti SS reichsfiureriui $\mathrm{H}$. Himleriui ${ }^{12}$. Rinkiniuose esantys dokumentai papildè jau iki to laiko plačiajai visuomenei žinomus faktus. Be to, leidinyje pateiktos vokiečių saugumo policijos ir SD vadų Lietuvoje kai

\footnotetext{
${ }^{8}$ A. Bulota, Nuo balto žirgo iki svastikos, Vilnius, 1962, p. 45-46.

${ }^{9}$ Masinès žudynès Lietuvoje (1941-1944), Dokumentų rinkinys, I dalis, Vilnius, 1965.

${ }^{10}$ Masinès žudynės Lietuvoje (1941-1944), Dokumentų rinkinys, II dalis, Vilnius, 1973.

11 Nors turejo slaptumo žymą „Geheime Reichssache“, šio dokumento buvo atspausdinta ir išplatinta 40 kopijų.

12 Нюрнбергский процесс, Москва, 1960, т. VI, с. 305; Malczużyński K. Oskarżeni nie przyznają się do winy, Warszawa, 1981, s. 253.
} 
kurių kasmėnesinių RSHA ataskaitų apie padètį Lietuvoje ištraukos.

Trumpai apie vokiečių saugumo policijos ir SD vadovybès funkcijas kontroliuojant Lietuvos pramonę bei siunčiant darbo jègą i Vokietijos karinès pramonès įmones bei žemės ūkị rašè K. Rukšènas ${ }^{13}$. Apsigintoje istorijos mokslų kandidatineje disertacijoje ${ }^{14} \mathrm{~K}$. Rukšènas bando skaitytojams pateikti, kiek tai buvo įmanoma sovietiniame moksle, vokiečių karinių bei policinių struktūrų Lietuvoje vaizdą. Tačiau jo disertacijoje yra vienokių ar kitokių faktografinių netikslumų.

1969 m. nedideliu tiražu (tik 700 egzempliorių) Lietuvos TSR Mokslų Akademijos Ekonomikos institute išleista J. Bulavo monografija „Vokiškujų fašistų okupacinis Lietuvos valdymas (1941-1944 m.)“. Remdamasis archyvinių šaltinių bei įvairių vokiškų dokumentų, atitinkamos literatūros ir to meto gyvenimo faktų analize, autorius visapusiškai pateikia ir apibūdina vokiečių Lietuvos valdymo laikotarpị. Atskleisdamas monografijos temą, J. Bulavas rašo, kad „aukščiausia policijos isstaiga Lietuvoje buvo vokiškasis saugumas (gestapas ir SD), pavaldus betarpiškai Reicho saugumo ịstaigai (Himleriui) ir generaliniam komisarui Lietuvoje"15. Kitoje vietoje autorius rašo, kad ,jam (Rosenbergui - P. S.) buvo betarpiškai pavaldūs $<\ldots>$ SS, gestapo ir SD viršininkai“"16.

1970 m. išleistame dokumentų rinkinyje „Nacionalistų talka hitlerininkams“17 yra pateikiama daug dokumentų, saugomų Lietuvos archyvuose, nuorašų. Tarp kitų dokumentų pateikiamas visas lietuvių saugumo policijos skyriaus prie vokiečių saugumo policijos ir SD vado Lietuvoje viršininko S. Čenkaus raštas K. Jegeriui su prašymu nelikviduoti šios tarnybos, kuri taip reikalinga kovojant su bendru priešu - bolševizmu. Čia pat pateikiama keletas vertingų ir nagrinejjamai temai įdomių dokumentų.

Istorikas Algirdas Rakūnas savo monografijoje „Lietuvos liaudies kova prieš hitlerinę okupaciją“18, remdamasis vokiečių saugumo policijos ir SD vado Lietuvoje mėnesinėmis ataskaitomis Vyriausiajai Reicho saugumo valdybai, teigia, kad ,policijos ịstaigos ir esesininkai buvo pavaldūs SS ir

\footnotetext{
13 K. Rukšènas, İ vergovę, Vilnius, 1966.

${ }^{14}$ K. Rukšèno disertacija „Hitlerininkų politika Lietuvoje 1941 - 1944 metais“, 1970. Asmeninis autoriaus archyvas.

15 J. Bulavas, Vokiškųų fašistų okupacinis Lietuvos valdymas (1941-1944 m.), Vilnius, 1969, p. 71-72.

16 Ten pat, p. 96.

${ }^{17}$ Nacionalistų talka hitlerininkams, Vilnius, 1970

18 A. Rakūnas, Lietuvos liaudies kova prieš hitlerinę okupaciją, Vilnius, 1970.
} 
policijos Lietuvoje štabui (išskyrus saugumo policiją ir SD, kurią minètasis štabas turejjo teisę kontroliuoti)“ (p. 34). Deja, autoriui pritrūko tikslumo ir nuoseklumo. Vienoje vietoje A. Rakūnas rašo apie „operatyvinę grupę 3/A“, o kitame puslapyje ši padalinị ịvardija kaip operatyvinị būrị (p. 39). Abejonių sukelia iš ne visai patikimo šaltinio (mènraštis „Švyturys“) cituojama operatyvinio būrio „ataskaita apie pasipriešinimo judejjimą Ostlande“, kuris (Ostlandas - P. S.) nebuvo jo tyrinëjamas. Nors A. Rakūno veikalas turi rimtų trūkumų, tam tikri jo teiginiai, kur cituojami autentiški vokiečių dokumentai, yra naudingi to laikotarpio tyrinètojams.

Nesumažinant daugybės knygų bei straipsnių apie Antraji pasaulini karą autorių nuopelnų, tenka konstatuoti, kad nemaža jų dalis yra paviršutiniški. Sovietmečiu istorija buvo paversta valdžios tarnaite ir todèl Antrojo pasaulinio karo istorija ne kartą buvo perrašoma, pataikaujant vis naujam partijos lyderiui. Kai kurių karo epizodų prisiminti apskritai buvo nepriimta. Po sovietinio režimo žlugimo Lietuvoje Antrojo pasaulinio karo įvykius mūsų šalyje stengiamasi pateikti ir interpretuoti naujoviškai, mažiau politizuotai, skelbiant naujus duomenis bei istorinius faktus. Dienos šviesą išvydo nemažai istoriją gvildenančių periodinių leidinių, kuriuose lietuvių istorikai turi galimybę skelbti savo tiriamuosius darbus.

Lietuvos politinių kalinių ir tremtinių sajungos leidinys „Laisvės kovų archyvas“ paskelbè vyriausiojo karo komendanto Lietuvoje 1941-1944 m. gen. mjr. Emilio Justo pokarinius parodymus sovietų tardymo organams ${ }^{19}$. Juose tardomasis pasakoja apie vokiečių valdžios struktūras Lietuvoje, pareigybių pasiskirstymą ir t. t. Pateikia šiokios tokios informacijos ir apie šiame straipsnyje nagrinejjamą instituciją. Perskaičius generolo parodymus, susidaro dvejopas ịspūdis: arba Vermachto generolas nepakankamai buvo susipažinęs su savo šalies policijos struktūra bei jos funkcijomis ir nesugebėjo aiškiai ịvardyti jos atliekamo darbo Lietuvoje, arba specialiai davė miglotus parodymus savo priešams. Jau vien jo, kaip vyriausiojo karo komendanto Lietuvoje, teiginys, kad su SD ir gestapo vadu Lietuvoje nepalaike jokių tarnybinių ryšių, kelia nuostabą ${ }^{20}$. Tačiau tai jo neišgelbèjo ir jis atsidūrè Vilniaus Tuskulènų kapavieteje.

Išeivijoje gyvenęs lietuvių žurnalistas ir sociologas A. Gražiūnas, naudodamasis gausia faktografine medžiaga, parašè knygą apie mūsų Tẻvynę dviejų

${ }^{19}$ Lietuviai okupantų vokiečių akimis. Generolo Emilio Justo parodymai. Laisvės kovų archyvas, t. 9-10, Kaunas, 1993-1994.

20 Ten pat, t. 10, Kaunas, 1994, p. 190. 
okupacijų replèse ${ }^{21}$. Pasinaudodamas gausiais šaltiniais, dokumentų vertimais, karo meto ir pokario išeivijos spauda, autorius aprašè vokiečių valdomą Lietuvą. Tačiau negalėdamas tirti autentiškų archyvinių šaltinių, autorius, rašydamas šiame darbe nagrinèjama tema, neišvengè rimtų klaidų bei netikslumų: Einsatzgruppe A vado pavardę rašo „Stahleris“ (p. 218), Jeckelną îvardija kaip „vokiečių saugumo policijos ir SD vadą Ostlande“ (p. 205), mini jokiuose archyviniuose dokumentuose nefigūruojantị mịslingą „Arnsą“, kaip vokiečių SS ir policijos vadą Lietuvoje (p. 358). Randame ir kitų netikslumų.

Užuominų apie vokiečių saugumo policiją ir saugumo tarnybą Lietuvoje yra lietuvių išeivijos autorių pokario darbuose. Lietuvių aktyvistų fronto igaliotinio Leono Prapuolenio prisiminimuose ${ }^{22}$, išleistuose, deja, tik 300 egzempliorių tiražu, pasakojama, kaip vokiečių saugumo policijos ir SD vadovų Kaune skatinamas Lietuvių nacionalistų partijos (voldemarininkų) atstovas J. Pyragius su savo bendraminčiais $1941 \mathrm{~m}$. liepos 23 - 24 d. surengė pučą prieš Lietuvos laikinają vyriausybę (toliau - LLV) ir likvidavo LLV atkurtą Kauno karo komendantūrą. Patị prisiminimų autorių ankstyvą rugsèjo 27 d. rytą suėmė SD pareigūnas Richardas Valdemaras Šveiceris (Richard Waldemar Schweizer ${ }^{23}$. Savo pokario prisiminimuose Priverčiamojo darbo valdybos viršininkas Bronius Aušrotas rašo ${ }^{24}$, kaip vokiečių saugumas griežtai kontroliavo ịkalinimo ịstaigas Lietuvoje. Karo metais lietuvių saugumo policijos Kauno apygardos valdybos Sekimo dalies viršininkas Juozas Grušys savo atsiminimų knygoje ${ }^{25}$ rašo, kaip ịkandin vokiečių armijai atvyko Einsatzgruppen (EG) daliniai. Gen. Stasys Raštikis atsimena ${ }^{26}$, kad jam „teko susidurti su ịvairiais vokiečių pareigūnais“, tarp jų ir su saugumo policija.

Apie straipsnyje nagrinèjamą vokiečių instituciją užsimena ir įžymus išeivijos atstovas Adolfas Damušis savo „matematinèje“ studijoje apie Lietuvos netektis karo ir pokario metais ${ }^{27}$. Deja, ir jis neišvenge gan rimtų klaidų. Pasiremdamas autoritetingu H. Krausnicko veikalu ${ }^{28}$, autorius klaidin-

21 A. Gražiūnas, Lietuva dviejų okupacijų replèse: 1940-1944. Vilnius, 1996.

22 L. Prapuolenis, Gestapo pavedimu... (Prisitaikymo politikos apraiškos 1941 m.), Vilnius, 2000.

${ }^{23}$ Vokietis, gimęs Lietuvoje, Einsatzgruppen „A“ vertèjas.

24 B. Aušrotas, Laisvès niekas nežadėjo, Vilnius, 1990.

25 J. Grušys-Žilvinas, Laukti nebuvo kada, Marijampolè, 2000.

26 S. Raštikis, Kovose dėl Lietuvos: kario atsiminimai, d. 2, Vilnius, 1990.

27 A. Damušis, Lietuvos gyventojų aukos ir nuostoliai antrojo pasaulinio karo ir pokario (19401959) metais, Kaunas, 1991.

${ }^{28}$ H. Krausnick, H. H. Wilhelm, Die Truppe des Weltanschauungskrieges. Die Einsatzgruppen der Sicherheitspolizei und des SD 1938-1942. Stutgart, 1981. 
gai teigia, kad „kiekviena Einsatzgrupe buvo sudaryta iš penkių komandų“ (vien EG „A“ turejo jų vienuolika, EG „B“ - septynias, EG „C“ - penkias, EG „D“- septynias - P. S.), kad „A Einsatzgrupès 2, 3 ir 8 komanda žygiavo per Lietuvos teritoriją su Šiaurès Vermachto grupe“ (p. 67) (komandos su indeksu 8 EG „A“ niekados nebuvo - P. S.), o generolą F. V. Štalekeri pažemina iki pulkininko laipsnio (p. 72). Reikia paminèti šio autoriaus ir kitus i̊domius darbus, susijusius su vokiečių saugumo policija Lietuvoje ${ }^{29}$.

Izidoriaus Ignatavičiaus dèka 1999 m. Lietuvos skaitytojus pasiekẻ knyga - rinkinys apie pusès amžiaus lietuvių tautos kovą su pavergèjais ${ }^{30}$. Ją recenzavo būrys (net 6!) garbių Lietuvos istorikų, tačiau, deja, mane dominančiame skyriuje „Hitlerinè okupacija“ nesugebejjo įžvelgti daugybės rimtų istorinių netikslumų. Viename iš rinkinio straipsnelių I. Itakis rašo, kad „pirmosiomis karo dienomis Lietuvoje èmé veikti SS ir gestapas“ (p. 72), o kitame puslapyje teigia, kad „pačioje Lietuvoje gestapas neįsikūre““ (p. 73). Toliau autorius rašo, kad „Gestapas ir komendantūra (skliausteliuose pateikia vokiškai saugumo policijos ir SD vado Lietuvoje pareigu pavadinimas - P. S.) Kaune ėmé veikti tada, kai $\langle\ldots>$ panaikino LLV“. Dẻl nežinomos priežasties autorius nurodo, kad pirmojo vokiečių saugumo policijos ir SD vado Lietuvoje vardo pirmoji raide „F“, adaptuotai pavardę rašo „Jègeris“, o originalo forma skliausteliuose pateikia „Jöger“ (p. 73). Kito greta esančio straipsnelio autorius I. Ignatavičius nurodo, kad minimo vokiečiu pareigūno pavardė „Jegeris“, o vardo pirmoji raide „J“ (p. 78). Abu autoriai kaip susitarę teigia, kad Jegeris buvo gestapo vadas Lietuvoje. Be to, antrojo straipsnelio autorius klaidingai pateikia „nacių partijos“ abreviatūrą kaip „NSDPA“ (p. 75). I. Ignatavičius nenurodo šaltinio, kuriuo rèmèsi rašydamas apie vokiečių saugumo policijos ir SD operatyvines grupes, nes pateikia klaidingą informaciją, teigdamas, kad jų sudètyje buvo „po 200 - 300 esesininkų kiekvienoje“. Toliau autorius klaidina skaitytoją rašydamas, kad „grupėse buvo po 5 komandas (SS Einsatzkommando), o šios susidejjo iš ypatingų būrių (SS Sonderkommando)“.

Dokumentų ir straipsnių rinkinyje „Lietuvos žydų žudynių byla“ (sudarytojas A. Eidintas) $)^{31}$ ịvairių autorių darbuose neapsieita nepaminëjus vokiečių saugumo policijos ir SD operatyvinių grupių ir saugumo policijos ir SD „nuopelnų“ Lietuvoje. Vieno nedidelio straipsnelio autorius (A. Astaška),

29 A. Damušis, Lietuvių pogrindis vokiečių saugumo policijos dokumentuose, İ laisvę, 1983, Nr. 88 (125).

${ }^{30}$ Lietuvos naikinimas ir tautos kova (1940-1998), Vilnius, 1999.

${ }^{31}$ Lietuvos žydų žudynių byla. Sudarè A. Eidintas, Vilnius, 2001. 
nepateikdamas šaltinio, o sudarytojui nepatikrinus, teigia, kad „Einzatzgrupejje A buvo 1200 žudikų, iš jų 350 esesininkų, 150 vairuotojų ir mechanikų, 100 gestapininkų, 40-50 kriminalinès policijos pareigūnų, 85 SD (žvalgybos) darbuotojų, 130 policininkų ir 80 pagalbinès policijos pareigūnų, išrenkamų vietoje“32. Toliau dar daugiau netikslumų: „A. Lileikis ir kiti jo pavaldiniai kaip tik ir buvo tarp tų vietose parenkamų „pagalbinès policijos pareigūnų“33. Deja, darbe pasigendama rinkinio sudarytojo A. Eidinto tikslesniu paaiškinimų bei komentarų.

Be paminètų leidinių, vokiečių saugumo policija ir SD minima ir kituose veikaluose ${ }^{34}$.

Iš Antrojo pasaulinio karo Lietuvoje laikotarpio problematiką tyrinèjančių lietuvių mokslininkų išsiskiria Arūnas Bubnys, kuris yra parašęs daug rimtų studijų. Rašydamas darbą „Lietuvių antinacinė rezistencija 1941-1944 m.“ autorius, šalia kitų šaltinių, remiasi vokiečių saugumo policijos ir SD slaptų agentų pranešimais apie lietuvių antinacinès rezistencijos dalyvių veiklą Tačiau šiame gan išsamiame veikale autoriui nepavyko išvengti ir dalykinių klaidų: „Jekelį“ jis įvardija kaip „Rytų krašto vokiečių saugumo policijos ir SD vadą“ (p. 25). A. Bubnys paruošè nemažai darbų, tiesiogiai susijusių su vokiečių saugumo policijos ir SD institucija ${ }^{36}$. Straipsnyje „Vokiečių ir lietuvių saugumo policija (1941-1944)“ autorius trumpai aptaria dviejų policijų organizacines struktūras. Rašydamas apie EG „A“ atsiradimą Lietuvoje, A. Bubnys sumažina grupès dydị iki keturių padalinių, tuo tarpu jos sudètyje buvo šešios Einsatzkommandos ir penkios Sonderkommandos. Kaip teisingai savo darbe pastebi A. Bubnys, svarbiausi vokiečių saugumo policijos ir SD vado Lietuvos generalineje srityje įstaigos skyriai buvo III (SD) ir IV (Gestapo).

Lietuvoje, deja, negausioje vokiečių saugumo policijos ir SD lietuvių istoriografijoje yra įvairaus pobūdžio klaidų bei prieštaringų faktų ir duomenų. Daugelio autorių darbų trūkumas tas, kad jie savo veikaluose po adaptuotos vokiškos pavardès, minėdami ją pirmą kartą, skliaustuose nepateikia jos ori-

\footnotetext{
32 Ten pat, p. 589.

33 Ten pat.

34 Pirčiupio tragedijos kaltininkai, Vilnius, 1975; V. Žeimantas, Teisingumas reikalauja, Vilnius, 1984; V. Žeimantas, Procesas nesibaigia, Vilnius, 1988; Lietuva. Lietuvių enciklopedija, penkioliktas tomas, Vilnius, 1990; J. R. Misiūnas, R. Taagepera, Baltijos valstybės: Priklausomybès metai 1940-1980, Vilnius, 1992; Atminties dienos, Vilnius, 1995.

35 A. Bubnys, Lietuvių antinacinè rezistencija 1941 - 1944 m., Vilnius, 1991.

36 A. Bubnys, Vokiečių ir lietuvių saugumo policija (1941 - 1944), Genocidas ir rezistencija, 1997, Nr. 1.
} 
ginalo forma. Ši pastaba ypač skirta autoriams, rašantiems rusų kalba. Dèl šios priežasties autoriams, taip pat ir lietuviams, nesisekẻ susitarti dẻl vienodumo rašant vokiškas pavardes. Labiausiai jiems sudare sunkumų rašyti vokiškas pavardes su umliautais (ä, ü,ö). Tuomet autoriai jas iškreipdavo, kaip kas norėjo: vienur „fašistinès saugumo policijos ir SD vado SS štandartenfiurerio“ pavardė pateikiama kaip „Jugeris“37, kitur „Jegeris“38 ir pan.

Vertingos faktinès informacijos straipsnyje nagrinejjamai temai randame daugelyje mums pasiekiamų užsienio šalių autorių darbų ${ }^{39}$.

Tačiau ir čia yra nežinia iš kur paimtų faktų. Didžiausias kuriozas įvyko su SS štandartenfiurerio Karlo Jegerio nuotrauka. Niujorke išleistoje holokausto enciklopedijoje ${ }^{40}$ vienas iš sudarytojų, nerasdamas tikros pulkininko nuotraukos, rado kažkokio vokiečių parašiutininko nuotrauką su parašu „Fallschirmjäger“ ir pateikè ją kaip K. Jegerio. Ši klastotė pasikartojo daugelyje vèliau išleistų knygų bei interneto tinklalapyje. Ilgus metus tokia suklastota K. Jegerio nuotrauka kabojo Valstybiniame Vilniaus Gaono žydų muziejaus ekspozicijoje. O anglų publicistas Edvardas Krenkšou (Crenkschou) savo veikale sunkiai atskiria valstybinès slaptosios policijos (Gestapo) ir SD operatyvinių grupių kompetenciją.

Rusų prokomunistinių autorių duetas D. Melnikovas ir L. Čiornaja teigia, kad vokiečių operatyvinès grupės „savo kruviną kelią tarybine žeme pradejo $1941 \mathrm{~m}$. liepos mėnesį“, kad „liepos $8 \mathrm{~d}$. buvo duotas įsakymas apie operatyvinių grupių permetimą iš Lenkijos į naują karinių veiksmų teatrą - TSRS“41. O N. S. Aleksejevas rašo, kad operatyvinèse grupėse buvo 14000 tarnautojų $u^{42}$. Amerikiečių autorius Dž. Tolandas (John Toland) teigia, kad „vokiečių armijai iš paskos sekè keturios SS Einsatzgruppen po tris tūkstančius žmonių kiekvienoje “43. Lenkų istorikas M. Cyganskis (Mirosław Cygański) tvirtina, kad keturiuose Einsatzgruppen tarnavo apie 9 tūkstančiai žmo-

\footnotetext{
37 V. Žeimantas, Atpildas už nusikaltimus, Tiesa, 197802 19, Nr. 43.

38 Lietuvos naikinimas ir tautos kova (1940-1998), Vilnius, 1999, p. 78.

39 Martin Gilbert, Niekada per amžius. Holokausto istorija, Vilnius, 2001; К. Залесский, РСХА, Москва, 2004; О. Ю. Пленков, Третий Рейх. Нацистское государство, СанктПетербург, 2004; А. Зегер, Гестапо-Мюллер, Москва, 1997; M. Cygański, SS w ruchu narodowosocjalistycznym i w III Rzeszy 1925 - 1945, Poznań, 1978; The Einsatzgruppen Reports, Holocaust Library, New York, 2001 ir kt.

${ }^{40}$ Encyclopedia of the Holocaust, Edited by Israel Gutman, Macmillan Publishing Company, Vol. 2, s. 733.

41 Д. Мельников, Л. Черная, Империя смерти, Москва, 1987, с. 321.

42 Н. С. Алексеев, Злодеяния и возмездие, Москва, 1986, с. 258.

43 Джон Толанд, Адольф Гитлер, Кн. 2, Москва, 1993, с. 147.
} 
nių ${ }^{44}$. Niurnbergo proceso metu SD organizacijos gynejjas Gavlikas 1946 m. rugpjūčio 27 d. posėdyje pareiškè, kad „,iš viso visose keturiose operatyvinèse grupèse buvo nuo 1000 iki 1200 žmonių“, o žymuo „SD“ operatyvinių grupių oficialiame pavadinime nebuvo naudojamas ${ }^{45}$. Tuo tarpu gestapo istorikas R. Batleris rašo, kad „Einsatzgruppen, < .. > po 3000 žmonių suskirstytos ị grupes, vadinamas Einsatzkommando“ “46. Dž. Pulas knygoje „Hitleris ir jo slaptieji partneriai“ rašo, kad „< $<>>$ kiekvienoje Einsatzgrupeje buvo nuo 50 iki 1000 vyrų $<\ldots>$. Visi vyrai buvo SS nariai, išèję specialų apmokymą“47. Maskvietis K. Berezinas priskiria lietuvių saugumo policiją prie RSHA struktūrų, o A. Lileikị ịvardija kaip RSHA pareigūną ${ }^{48}$. Aleksandras Slavinas knygoje „Pompejos žūtis“ pateikia operatyvinès grupès „A“ pranešimų ištraukų apie padètị Lietuvoje pirmais karo ménesiais ${ }^{49}$.

Neišsenkamas informacijos apie SD veiklą bei užregistruotų ìvykių užimtose teritorijose šaltinis yra vokiečių saugumo policijos ir SD (tuo pačiu operatyvinių grupių) vadų raportai Vyriausiajai Reicho saugumo valdybai, pavadinti „Pranešimai apie ịvykius Sovietų Sajungoje“ (,,Ereignismeldungen UdSSR“). Jie apėmè laikotarpi nuo $1941 \mathrm{~m}$. birželio 23 d. iki 1942 m. balandžio 24 d. (iš viso 195 pranešimai) ${ }^{50}$ ir buvo parašyti labai preciziškai (buvo skirta vietos net oro sąlygų aprašymui). $1941 \mathrm{~m}$. birželio 27 d. pranešime Nr. 6 pirmą kartą pasirodo operatyvinių grupių informacija. Kitą tokio pobūdžio informaciją randame pranešime Nr. 8 (1941-06-30). Operatyvinių grupių vadai savo pranešimus RSHA teikdavo dviem būdais: pirmas - per radiją, kitas - raštu per kurjerị. Pranešimai per radiją buvo labai ịslaptinti: išskyrus vadą, jo pavaduotoją, vyriausiaji radistą ir kitą radijo personalą, niekas neturejjo teisės įžengti i radijo stoties patalpas. Pirmieji septyni apibendrinti „Pranešimai apie ivvykius Sovietų Sajungoje“ buvo pasirašyti SS grupenfiurerio H. Miulerio, tuo tarpu likusieji buvo platinami uždarame rate be parašo. H. Miulerio nurodymu, nuo rugpjūčio $1 \mathrm{~d}$. i̊sigaliojo įsakymas referuoti A. Hitleriui

\footnotetext{
${ }^{44}$ M. Cygański, SS w ruchu narodowosocjalistycznym i w III Rzeszy 1925 - 1945, Poznań, 1978, s. 379.

45 Нюрнбергский процесс, Москва, 1960, т. VI, с. 512, 515.

46 R. Batleris, Gestapo istorija, Kaunas, 1997, s. 250.

47 Dž. Pulas, Hitleris ir jo slaptieji partneriai, Kaunas, 1998, p. 206-207.

48 К. Березин, Дело нацистского преступника Лилейкиса, Вестник, No.12(246), 20 июня 2000 г.

49 А. Славин, Гибель Помпеи. Записки очевидца, Тель Авив, 1997.

50 Paskutinio pranešimo Nr. 195 buvo padauginta 75 egzemplioriai.
} 
raportus apie operatyvinių grupių veiklą Rytuose ${ }^{51}$.

1942 m. balandžio 16 d. vokiečių saugumo policijos ir SD vadas R. Haidrichas ịsakẻ nutraukti šių pranešimų ruošimą bei siuntinėjimą ir nurodẻ nuo 1942 m. gegužès 1 d. ruošti „Pranešimus iš užimtų rytinių teritorijų“ (,,Meldungen aus den besetzten Ostgebieten“). Iki 1943 m. gegužès 21 d. buvo paruošti $55^{52}$ šie pranešimai su grifu „Slaptai“ (,,Geheim“) po 100 egzempliorių kiekvienas. Iš viso buvo paruošta, padauginta bei išsiuntinèta kompetentingoms valstybinèms bei policinèms institucijoms 250 abiejų rūšių pranešimų, apimančių kelis tūkstančius puslapių.

Iki 1942 m. balandžio mèn. RSHA buvo paruošta vienuolika ${ }^{53}$ „Ataskaitų apie saugumo policijos ir SD veiklą bei situaciją Sovietų Sajungoje“ (,,Tätigkeits-und Lageberichte der Sicherheitspolizei und des SD in der UdS$S R$ “) ir pagal griežtą paskyrą išsiuntinèta adresatams NSDAP, Reicho ministerijose bei Vermachto struktūroms. Ataskaitos turejo aukščiausio slaptumo žymą: „Slaptai. Valstybinès reikšmès reikalas“ (,,Geheime Reichssache"). Pirmoji tokia ataskaita apėmè periodą nuo karo pradžios su Sovietų Sajunga iki 1941 m. liepos 31 d. Kitos penkios buvo leidžiamos kas dvi savaites iki 1941 m. spalio 31 d. Ataskaitos Nr. 7-11 jau buvo kasménesinès ir buvo nuo 1941 metų lapkričio 1 dienos iki 1942 m. kovo 31 d. Advokatai Niurnbergo procese gan skeptiškai vertino šiuos dokumentus: jie teigè, kad kai kurių ataskaitų autoriai, siekdami įtikti H. Himleriui, jei nesugalvodavo akcijų, kurių tikrovejje nebuvo, tai bent egzekucijų aukų skaičių smarkiai padidindavo. Istorikų laimei, visos šios ataskaitos (išskyrus Nr. 9) po karo buvo rastos Vokietijos užsienio reikalų ministerijos (Auswärtigen Amt) archyve ${ }^{54}$. Viename tokių saugumo policijos ir SD pranešimų buvo akcentuojama, kad „Lietuva nekariauja su Vokietija“55, kitame - kad A. Voldemaro šalininkai ketino apsiriboti autonomijos reikalavimais savo kraštui, tai yra kaip suteikti Vokietijai galimybę formuoti Lietuvos užsienio politiką $a^{56}$, o trečiame išanalizuojamas ir apibūdinamas lietuvių tautinis pasipriešinimo judejjimas ${ }^{57}$.

${ }^{51}$ G. Knopp, SS przestroga historii, Warszawa, 2004, s.181.

52 M. Morašini nurodo, kad jų buvo 50. - Michel Moracchini, Les troupes speciales d'Hitler, 2001, s. 137.

53 Ten pat.

54 J. Kubiszyn, Jedwabne - droga do prawdy? „Nasz dziennik“, 12122002.

55 М. И.Семиряга, Тюремная империя нацизма и ее крах, Москва, 1991, с. 269.

56 М.Ю. Крысин, Прибалтика между Сталиным и Гитлером, Москва, 2004, с. 133.

${ }^{57}$ LCVA, f. R-1399, ap. 1, b. 33, 1. 12. 
„Pranešimus iš užimtų rytinių teritorijų“ bei „Ataskaitas apie saugumo policijos ir SD veiklą bei situaciją Sovietų Sajungoje“ ruošdavo RSHA skyrius IV A 1, vadovaujamas SS šturmbannfiurerio Kurto Lindovo (Kurt Lindow) ${ }^{58}$, bei daktaras Giunteris Knoblochas (Dr. Günter Knobloch) ${ }^{59}$. Šio skyriaus kompetencijoje buvo komunizmas, marksizmas bei mažesnès svarbos organizacijos, kariniai nusikaltimai, nelegali ir legali priešo propaganda. Nuo $1941 \mathrm{~m}$. spalio $21 \mathrm{~d}$. šis skyrius buvo reorganizuotas i „Vadovaujantị štabą“ (,Kommandostab“), kuris papildomai ėmėsi vadovauti RSHA žvalgybai. „Vadovaujantis štabas“ buvo ịpareigotas atrinkti ir įvertinti operatyvinių grupių bei būrių, dalyvaujančių operacijoje „Barbarossa“, pranešimus. Partinès nomenklatūros spaudžiamas, kuriai nepatiko SD kišimasis į jos reikalus, H. Himleris $1944 \mathrm{~m}$. buvo priverstas uždrausti SD suvestinių sudarymą bei platinimą ${ }^{60}$.

Šiuo straipsniu autorius nepretenduoja išsamiai atskleisti Vokietijos saugumo policijos ir SD institucijos buvimo bei veiklos Lietuvos generalinèje srityje Antrojo pasaulinio karo metais. Ši studija, manau, padès suprasti šios Trečiojo Reicho policinès struktūros esmę, funkcijas bei organizacinę struktūrą. Studijos pagrindinis tikslas - remiantis kai kuriais patikimais Lietuvos archyvų šaltiniais, karo meto periodiniais leidiniais, pokario moksline literatūra, ją kritiškai nagrinejjant ir vertinant, išanalizuoti vokiečių saugumo policijos ir SD institucijos misiją ir vaidmeni Lietuvos generalinèje srityje 1941-1944 m., pristatyti šios institucijos Lietuvoje vadovus ir jų likimus bei aptarti kitus su straipsniu susijusius klausimus. Šioje studijoje pirmą kartą lietuvių istoriografijoje pateikiamos vokiečiu saugumo policijos ir SD vadovybės Lietuvoje bei SD operatyvinių grupių „A“ ir „B“ organizacinès schemos, operatyvinių grupių valdymo sistema, vokiečių saugumo policijos ir saugumo tarnybos Ostlande ir Lietuvos generalineje srityje 1941-1945 m. schema, Vokietijos saugumo policijos ir saugumo tarnybos (SD) schema, archyvinès nuotraukos iš asmeninio autoriaus archyvo.

\footnotetext{
58 Gimė 1903-02-16 Berlyne. Filosofijos daktaras. 1935 tapo SS nariu Nr. 272350, o nuo 193705-01 NSDAP nariu Nr. 4609289. Nuo 1941-03-01 kriminalinis komisaras ir RSHA referato IVA1 vadovas. Nuo 1942 iki 1944 RSHA IV valdybos kriminalinis direktorius, sekcijos IVA1a vadovas. 1948 nuteistas 3,5 metų kalejjimo. Atgavęs laisvę, dirbo Siemenso koncerne. Nuo 1960 parduotuvès savininkas Bielefelde (Westfalija).

${ }^{59}$ Gimè 1910-05-13. NSDAP Nr. 1025597, SS Nr. 290998. Nuo 1938-07-02 SS unteršturmfiureris ir SD-Hauptamt pareigūnas.

${ }^{60}$ Vakarų Vokietijos mokslininkas Heinz Boberach surinko ir 1986 metais išleido visus slaptus $\mathrm{SD}$ biuletenius (iš viso 17 tomų).
} 


\section{Ab incunabulis (Viskas prasideda nuo lopšio (lot.))}

\section{Nacistinès Vokietijos saugumo policija ir SD iki Antrojo pasaulinio karo}

Be retrospektyvaus žvilgsnio ị vokiečių saugumo policijos ir SD genezę, neišanalizavus šios labai svarbios Trečiojo Reicho slaptos policinès institucijos atsiradimo peripetijų, neįmanoma pateikti jos vaidmens karo metais Lietuvos generalinejje srityje. $1931 \mathrm{~m}$. iš pačių patikimiausių „bendrujų SS“ narių NSDAP (Nationalsozialistische Deutsche Arbeiterpartei, NS$D A P$ - Vokiečių nacionalsocialistinė darbininkų partija) vadovybė sudarè specialią SS formuotę - vadinamają „saugumo tarnybą“, 1932 m. liepos 29 d. performuotą i SS reichsfiurerio Saugumo tarnybą - SD (Sicherheitsdienst des RFSS). Nuo $1931 \mathrm{~m}$. spalio $1 \mathrm{~d}$. naujai įsteigtos tarnybos vadovu buvo paskirtas dvidešimt septynerių metų jūrų vyr. It. Reinhardas Haidrichas (Reinhard Haidrich). Nepastebimai SD ịsiskverbe i i visas Vokietijos politines partijas, tvirtai ịsigalèjo spaudoje bei kultūros ịstaigose. SD tapo savotiška NSDAP „namine policija“. Svarbiausias SD uždavinys iki 1933 m. buvo sekti nacizmo priešininkų partijas bei organizacijas, taip pat stebėti NSDAP, kad nekiltų vidinių sąmokslų.

$1934 \mathrm{~m}$. birželio $9 \mathrm{~d}$. nutarimu SD buvo paskelbta vienintele NSDAP slaptaja žvalgybos ir kontržvalgybos tarnyba, su kuria kiekvienas pilietis privalëjo bendradarbiauti. Taigi NSDAP tapo valdančiaja partija, kuri, esant valstybinėms saugumo tarnyboms, turèjo nuosavą specialiają tarnybą. Nei prevencinio sulaikymo, nei suemimo, nei tardymo SD atlikti savarankiškai negalejo - viskas buvo Gestapo ir kriminalinès policijos prerogatyva.

1935 m. sausio 30 d. SD padètis vèl buvo paaukštinta: dabar R. Haidricho vadovaujama organizacija pradejo vadintis Vyriausiaja SD valdyba (SD-Hauptamt arba SS-Sicherheitshauptamt $)^{61}$. Vyriausiosios SD valdybos sudètyje buvo trys valdybos (Amt), iš jų III-oji valdyba (III-Auslandsnachrichtendienst) organizavo užsienio žvalgybą ${ }^{62}$. III-oji valdyba buvo padalinta i du centrinius skyrius: III 1 (vidine informacine tarnyba) ir III 2 (išorinė politinẻ kontržvalgyba). Antras centrinis skyrius dalijosi ị penkis skyrius, o skyrius III 111 (Rytų Europa) domėjosi ir Lietuva. SD rezidentai užsienyje veikè dažniausiai prisidengę diplomatine padėtimi.

61 A. Ramme, Służba bezpieczeństwa SS, Warszawa, 1975, s. 56.

62 W. Schellenbergas, Atsiminimai, Kaunas, 2000, p. 12. 


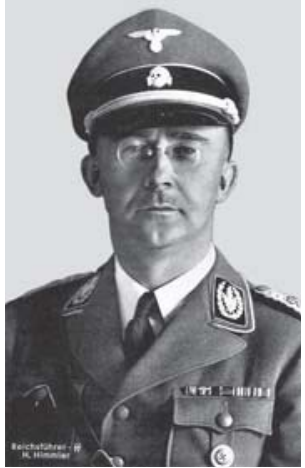

Vokiečiu policijos ir SS vadas reichsfiureris Heinrichas Himleris

Nuo to laiko, kai 1936 m. birželio 17 d. H. Himleris tapo vokiečiu policijos vadovu ${ }^{63}$, o R. Haidrichui, SD viršininkui, buvo perduotas vadovavimas saugumo policijai, tai pastarasis sutelkẻ savo rankose tokios apimties valdžią, kurios iki šiolei neturejjo né vienas policijos valdininkas per visą Vokietijos istoriją. Vèliau, $1938 \mathrm{~m}$. birželio 23 d. dekretu, buvo nurodyta, jog visas saugumo policijos (gestapo ir kriminaliné policija) personalas turi įstoti ị SS gretas ${ }^{64}$.

SD ir Gestapo veiklos sferos dažnai susikirsdavo, todèl tarp jų kildavo tam tikra trintis. Gestapo vadovas Heinrichas Miuleris (Heinrich Müller), profesionalus policininkas, giliai niekino SD ir jos ,intelektualus“. SD sekimo mašina tapo tokia aktyvi, kad jos agentai neišvengiamai lipo ant kulnų Gestapo pareigūnams, atliekantiems panašų darbą ir turintiems vykdomają galią suimti bei izoliuoti. Susiklosčiusioje situacijoje R. Haidrichas nutare padaryti tvarką. Nuo 1937 m. liepos 1 d. jis išleido „Instrukciją apie funkcijas“, kurioje padalijo veiklos sritis tarp šių žinybų: Gestapui atiteko daug pavojingesni nacionalsocializmui marksizmas, valstybiniai nusikaltimai, emigracija, o SD - mokslas, menas, auklejjimas, partija, valstybè, konstitucija, užsienis, masonai. Gestapas tapo Trečiojo Reicho rankomis, o SD - akimis ir ausimis. Laipsniškai SD pareigūnų skaičius augo: $1932 \mathrm{~m}$. joje buvo 33 pareigūnai, o 1933 m. SD nariais buvo 9465, 1934 m. - 204, 1935 m. - 224, 1936 m. - 269, 1937 m. - 372 karininkai ir puskarininkiai ${ }^{66}, 1938$ m. pr. - 5050, o metų pabaigoje - $7230^{67} .1937 \mathrm{~m}$. ,patikimų asmenų“ skaičius - taip buvo vadinami savanoriai pagalbininkai - išaugo iki 50 tūkstančių ${ }^{68} .1943$ m. SD gretose buvo

63 Oficialiai jo pareigos skambèjo taip: SS reichsfiureris ir vokiečiu policijos vadas Reicho vidaus reikalų ministerijoje. Šios pareigos leido H. Himleriui pavaduoti ministrą ir dalyvauti Vyriausybès posėdžiuose. 1937-05-15 H. Himleris nustate, kad jo štabo potvarkiai turi vidaus reikalų ministro įsakymo galią.

${ }^{64}$ E. Crankshaw, Gestapo - narzędzie tyranii, Warszawa, 1960, s. 90.

65 Encyklopedia II Wojny światowej, Warszawa, 1975, s. 563 teigiama, kad 1933 m. SD buvo 170 pareigūnų karininkų.

${ }^{66}$ A. Ramme, Służba bezpieczeństwa SS, Warszawa, 1975, s. 57.

67 M. Cygański, SS w ruchu narodowosocjalistycznym i w III Rzeszy 1925 - 1945, Poznań, 1978, s. 250 .

68 К. Залесский, РСХА, Москва, 2004, стр. 21. 
GEHEIME

STĀATSPOLIZEI

301

Gestapo pareigūno tarnybos žetonas

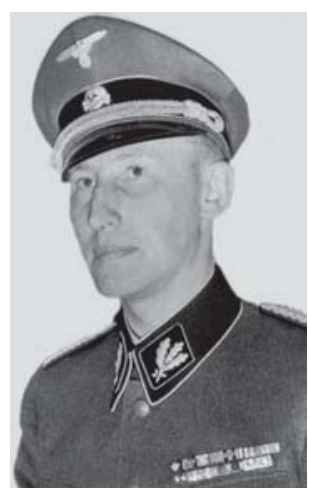

Vyriausiosios Reicho saugumo valdybos viršininkas SS obergruppenfiureris Reinhardas Haidrichas

3000 pareigūnų ${ }^{69}$, o 1944 m. vokiečiu užimtose teritorijose SD ir saugumo policijos padaliniuose tarnavo 19254 pareigūnai $^{70}$. Niurnbergo proceso metu SD organizacijos gynejjas Gavlikas pareiškè, kad karo metais $50 \%$ visų SD darbuotojų buvo moterys, neturejjusios teisès dèvèti SD unifor$\operatorname{mos}^{71}$. Labai ịslaptinta saugumo tarnyba užèmé svarbią vietą SS organizacijoje. 1937 m. SD pareigūnai sudarè tik 2,3\% visų SS narių, o SD vadų visame SS karininkų korpuse buvo net 10,7 \%

Paskutinè Trečiojo Reicho policinių tarnybų reorganizacija ìvyko 1939 m. Organizaciškai sujungus Vyriausiają saugumo policijos valdybą su Vyriausiaja saugumo tarnybos valdyba (SD valdyba), SS reichsfiurerio $\mathrm{H}$. Himlerio icsakymu 1939 m. rugsėjo 27 d. buvo ịkurta Vyriausioji Reicho saugumo valdyba (Reichssicherheitshauptamt - RSHA), suvienijusi, ši kartą jau instituciškai, SD, Gestapą ir kriminalinę policiją ${ }^{73}$. Formaliai abi vyriausiosios valdybos buvo pavaldžios Reicho vidaus reikalų ministrui V. Frikui (Wilhelm Frick), tačiau tikru jų vadovu buvo SS ir vokiečiu policijos vadas $H$. Himleris. RSHA tapo viena iš dvylikos vyriausiųjų SS valdybų. Jos vadovu buvo paskirtas saugumo policijos ir saugumo tarnybos vadovas SS grupenfiureris Reinhardas Haidrichas. Toji institucija, iš tiesų nepriklausanti Reicho vidaus reikalų ministerijos kompetencijai, buvo pavaldi tik H. Himleriui, o per ji - A. Hitleriui ${ }^{74}$. RSHA buvo sudaryta iš šešių, nuo 1940

${ }^{69}$ Encyklopedia II Wojny światowej, Warszawa, 1975, s. 564. Tuo metu Gestapo gretose kartu su pagalbiniu personalu buvo 40000 narių.

70 H. Höhne, Der Orden unter dem Totenkopf, Sigbert Mohn Verlag, Güterrslon, 1967, s.10.

71 Нюрнбергский процесс, Москва, 1960, т. VI, с. 499, 509. Sios studijos autorius šiais gynejo teiginiais labai abejoja.

${ }_{72}$ A. Ramme, Służba bezpieczeństwa SS, Warszawa, 1975, s. 91.

73 A. Hitlerio valdomoje Vokietijoje buvo negailestingai kovojama su kriminaliniais nusikaltimais, kurie sudare grèsme ne tik piliečiams, bet ir valstybei. Todèl ši kova buvo valstybès saugumu besirūpinančių institucijų kompetencijoje, konkrečiai - RSHA.

${ }^{74}$ W. Schellenbergas, Atsiminimai, p. 16. 
m. vid. - septynių, o karo pabaigoje - iš aštuonių valdybų. Būtent RSHA trečioji (Hauptamt für SD Taetigkeit im Innland) ${ }^{75}$, šeštoji (Hauptamt für $S D$ Taetigkeit im Ausland) ${ }^{76}$ ir septintoji (Amt für Weltanschauliche Forschung) valdybos ir buvo SS saugumo tarnyba - SD, ketvirtoji (Geheime Staatspoli$z e i-$ Gestapo) ir penktoji (Kriminalpolizei - Kripo) - saugumo policija (Sicherheitspolizei). RSHA, kaip valstybinè institucija, dar vadinama „žinyba, kurios nebuvo“, buvo ypač ịslaptinta - eiliniai Vokietijos piliečiai apie jos egzistavimą nieko nežinojo, o oficialiuose Trečiojo reicho dokumentuose ji neminima. R. Haidricho nurodymu, žymeni „RSHA“ galima buvo naudoti tik Reicho vidaus reikalų ministerijos viduje, o už jos ribų būtina naudoti tik „saugumo policijos ir SD viršininkas“"77. Buvo kategoriškai uždrausta

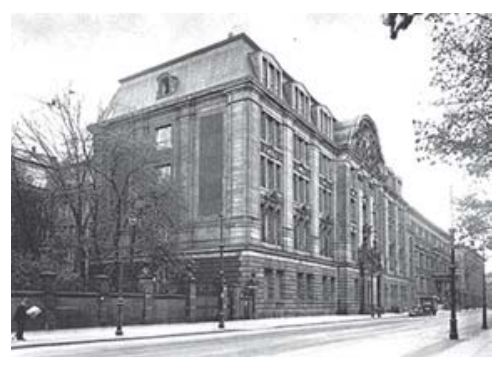

RSHA pastatas - Prinz-AlbrechtStrasse 8, Berlynas, 1932 m. nuotrauka šią instituciją minèti spaudoje bei oficialiame susirašinejjime. Nebuvo ịsteigta RSHA viršininko pareigybè, o jos vadovai (R. Haidrichas ir E. Kaltenbruneris) buvo ịvardijami kaip saugumo policijos ir SD vadai. Netgi vokiečių teisininkai nesugebejo įvardyti naujo mažai suprantamo valstybinio partinio naujadaro padèties. Jos centrinè būstinè buvo Berlyne, Prinz-Albrecht-Strasse gatvèje, nr. $8^{78}$, tačiau dauguma RSHA tarnybų buvo išmètyta po visą miestą 38 pastatuose.

Vokietijos teritorijoje bei Antrojo pasaulinio karo metais okupuotose srityse aukščiausioji vokiečių policinė institucija buvo ịvairaus rango SS ir vokiečių policijos vadovai (SS- und Polizeiführer). Ši institucija buvo įsteigta bendru Reicho bei Prūsijos vidaus reikalų ministrų 1937 m. lapkričio 15 d. potvarkiu $^{79}$. Ji atsirado igyvendinant bendrą mobilizacinị planą bei ruošiant

75 Šios valdybos grupès IIIB (vadovas SS oberšturmbannfiureris dr. Hansas Ehlichas) pogrupio IIIB2 kompetencijoje buvo Lietuva ir lietuviai.

76 Šios valdybos grupès VIC (vadovas SS šturmbannfiureris dr. Heinzas Grefe) kompetencijoje buvo sovietų įtakos sfera, o jos vieno iš trylikos referatų kompetencijoje buvo Lietuva (vadovas SS šturmbannfiureris dr. E. Hengelhauptas).

77 Нюрнбергский процесс, Москва, 1960, т. VI, с. 162.

78 Oficialus saugumo policijos ir SD pašto adresas.

79 K. Grünberg, SS gwardia Hitlera, Warszawa, 1994, s. 199. M. Cygański, op. cit., p. 231 ir 379 nurodo lapkričio 13 d. Šią datą patvirtina ir Mark C. Yerger knygoje „Allgemeine-SS. The Commands, units and leaders of the general SS", USA, 1997, s. 22. 
SS ir policijos struktūras būsimam karui. 1939 m. gruodžio mẻn. kiekvieno SS ir policijos vadovo žinioje buvo įsteigta saugumo policijos ir SD inspektoriaus (vado/viršininko) pareigybė.

1940 m. gegužès 18 d. R. Haidricho išleistame cirkuliare buvo aprašyta griežta kandidatų i RSHA paruošimo programa. Kandidatas privalèjo būti jaunas ir baigęs teisès studijas SS mokykloje arba universitete. Keturis mėnesius jis turejjo stažuotis kriminalineje policijoje ir susipažinti su policijos darbo pagrindais, po to turejjo būti trijų mėnesių tarnyba iš eilès SD ir Gestape ir tik tada, ivvertinant potencialias galimybes bei nuopelnus, kandidatas galëjo būti pervestas ị vieną iš septynių RSHA valdybų. Be to, dauguma šios tarnybos pareigūnų privalëjo atlikti bent trumpalaikę karinę tarnybą, geriausiai fronte, kur jie turejo galimybę pademonstruoti savo narsą ir pelnyti kovini apdovanojimą. Tai turèjo išsklaidyti klaidingą ịspūdị, jog RSHA valdybų ir skyrių personalas - tai bailiai, „užnugario žiurkès“, besislapstančios už fronto linijos. Todèl dauguma vadovaujančių RSHA pareigūnų atliko tarnybą Rytuose SD operatyvinių grupių, operatyvinių būrių ir ypatingų būrių vadovų postuose, o ši tarnyba buvo prilyginama tarnybai fronte. Pats RSHA vadovas SS grupenfiureris R. Haidrichas, kaip Luftwaffes kapitonas, atliko trumpalaikę fronto tarnybą aviacijos padalinyje ir buvo apdovanotas koviniu ženklu.

Dar iki Vokietijos - SSSR karo, gavus tiesioginị A. Hitlerio ịsakymą, $1941 \mathrm{~m}$. ankstyvą pavasarị ${ }^{80}$ iš specialiuju policijos institucijų buvo sudarytos specialios motorizuotos ir labai mobilios vokiečiu saugumo policijos ir SD operatyvinès grupès (SS Einsatzgruppe), arba kitaip - „veiklos grupès“, priskirtos prie armijų grupių ir atskirų armijų. Operatyvinių grupių pavadinimas vokiečių kalba skamba taip: Einsatzgruppen der Sicherheistpolizei und des $S D$, nors SD karininkų skaičius juose tesudarè tik apie $3 \%$. Žmonių kiekiu jos prilygo batalionui. Šios grupès skirstomos į operatyvinius būrius (SS Einsatzkommando) (70 - 150 žmonių, juose 10 - 15 karininkų ir 40 - 60 puskarininkių), priskirtus prie armijų ir veikiančius jų operatyviniame užnugaryje, o pastarieji - ì ypatingus būrius (SS Sonderkomman$d o)^{81}(20$ - 30 žmonių), veikiančius armijų dislokavimo rajonuose. Vokiečių terminologijoje išskirtiniais atvejais terminas Sonderkommando buvo var-

80 Konkrečios datos nepavyko surasti. Teisès mokslų daktaras Aleksejjëvas N. S. teigia, kad šios operatyvinès grupès buvo pradètos formuoti ruošiant operaciją „Jūrų liūtas“ prieš Angliją, o tik vèliau buvo reformuotos veiklai Rytuose. Н. С. Алексеев, Злодеяния и возмездие, Москва, 1986, с. 17.

81 A. Mollo, Uniforms of the SS. Volumne 5: Sicherheitsdienst und Sicherheitspolizei 1931 - 1945. London, 1992. P. 19. 
tojamas pažymèti ypatingos paskirties daliniui nebūtinai SS struktūroje. Prie kai kurių operatyvinių būrių buvo sudaryti mažesni būriai, vadinami SS Teilkommando (20 - 30 žmonių). Visi mobilūs operatyvinès grupės padaliniai turëjo lengvuosius ir specialiuosius automobilius, sunkvežimius ir motociklus, ginkluoti moderniausiais automatiniais ginklais. Kiekvienos operatyvinės grupės štabas susidejo iš adjutantūros ir penkių skyrių: jungtinio I/II (administracija ir finansai), III (SD) ir jungtinio IV/V (gestapo/ kriminalinè policija).

Prancūzų autorius Mišelis Morašini (Michel Moracchini) nurodo, kad absoliutų visų operatyvinių grupių dydį nustatyti yra sunku. Atsižvelgiant ị pastovią kadrų rotaciją, žmonių skaičius keturiose grupése niekados neviršijo $5000^{82}$. Tarp operatyvinių grupių vadovų ir kitų karininkų, pasiųstų į Sovietų Sajungos teritoriją, buvo labai daug teisininkų ir kitų intelektualų ${ }^{83}$.

Iš pat pradžių, formuojant saugumo policijos ir SD operatyvines grupes, R. Haidrichas pajuto kariškių pasipriešinimą. Daugumai Vermachto generolų nepatiko, kad jų užnugaryje veiks SS ir Sipo baudžiamieji daliniai. Priešlėktuvinès artilerijos gen. Karlas fon Rokas (Karl von Roques) ${ }^{84}$ atvirai žygi i $\mathrm{Ru}-$ siją vadino „karine beprotybe“, J. fon Ribentropa - „idiotu“, o Einsatzgruppe narius - „galvažudžiais“. Pradèta ieškoti kompromiso. Kadangi saugumo policijos ir SD operatyvinès grupès Rytuose privalejjo veikti Vermachto jurisdikcijos teritorijoje, buvo paruošta daug teisès aktų, kurie reglamentavo saugumo policijos ir kariuomenès tarpusavio santykius bei paramą vienas kitam. 1940 m. SS brigadefiureris V. Bestas (W. Best) kartu su R. Haidrichu paruošè pagrindines SD ir saugumo policijos būsimos veiklos teisines nuostatas ,naujomis sąlygomis“, t. y. naujai užimtose teritorijose. 1941 m. sausio 4 d. tarp Vyriausiosios sausumos kariuomenès vadovybès (Oberkommando des Heeres - $O K H$ ) ir saugumo policijos ir SD viršininko R. Haidricho buvo sudaryta sutartis, pagal kurią saugumo policijos igaliotinis atlieka referento funkcijas prie kariuomenès vado konkrečioje teritorijoje bei vykdo jo nurodymus. Prieš tai, 1940 metų spalio 4 dieną, buvo pasirašytas Vyriausiosios ginkluotojų pajėgų vadovybès (Oberkommando der Wehrmacht - OKW) įsakymas apie

\footnotetext{
82 Michel Moracchini, Les troupes speciales d'Hitler, 2001, s. 27.

${ }^{83}$ Pavyzdžiui, SS Einsatzgruppe D vadas O. Olendorfas turejo trijų universitetų diplomus ir buvo teisès mokslų daktaras. E. Bibersteinas, vienas iš SS Einsatzgruppe $C$ vadovu, buvo protestantu pastorius, teologas ir bažnyčios tarnautojas.

84 Gimè 1880-05-07. Priešlèktuvinès artilerijos generolas, 1941-03-16 - 1942-12 armijų grupès „Šiauré“ užnugario kariuomenès vadas. Mirè 1949-12-24.
} 
saugumo policijos ir SD igaliotinio bei ypatingų komandų kompetenciją ${ }^{85}$.

Tuo pat metu tarp RSHA vadovo R. Haidricho ir $\mathrm{OKH}$ generalinio armijos intendanto gen. mj. Eduardo Vagnerio (Eduard Wagner) ${ }^{86} 1941 \mathrm{~m}$. kovo $13 \mathrm{~d}$. ìvyko pasitarimas dẻl operatyvinių grupių teisinès padèties karinio konflikto metu. $1941 \mathrm{~m}$. kovo 26 d. ir balandžio mèn. 4 d. tarp OKW Krašto apsaugos skyriaus viršininko gen. mj. Valterio Varlimonto (Walther Walrimont) ir Vermachto žvalgybos ir kontržvalgybos viršininko adm. Vilhelmo Kanariso (Wilhelm Canaris) pasirašyti susitarimai dẻl saugumo policijos rolès kariuomeneje. Buvo akcentuojama, kad turimų Vermachto policinių pajėgu (slaptoji lauko policija bei lauko žandarmerija) nepakaks sausumos kariuomenès operatyvinei erdvei apsaugoti. Vèliau, $1941 \mathrm{~m}$. birželio 10 d., netoli Berlyno ivvyko V. Kanariso ir R. Haidricho bei jų tarnybų atsakingu karininkų pasitarimas. Buvo aptarti bendradarbiavimo tarp Einsatzgruppen ir saugumo tarnybos bei armijos kontržvalgybinių padalinių (tarp jų specialaus pulko „Brandenburg“) klausimai ir pasirašyta sutartis dèl kompetencijos apribojimo bei ginkluotujų pajėgų bendradarbiavimo su SS operatyvinèmis grupèmis būsimame kare su Sovietų Sajunga. Buvo nustatyta, kad ryšininkais tarp Einsatzgruppen ir kariuomenès bus prie kiekvienos armijos, korpuso ar divizijos štabo veikiantys Ic karininkai, kaip žvalgybos vadovai. Einsatzgruppen vadas buvo ịpareigotas teikti raštiškus pranešimus žvalgybos vadovams ${ }^{87}$. Kariuomenès vadovybė buvo paskirta atsakinga už operatyvinių grupių materialinị bei techninị aprūpinimą. 1941 m. balandžio 28 d., likus mažiau nei dviem mėnesiams iki operacijos „Barbarossa“ igyvendinimo, šis susitarimas buvo iformintas Vermachto sausumos kariuomenès vado gen. plk. Valterio fon Brauchičo (Walther von Brauchitsch) slaptu isakymu „Dèl saugumo policijos ir SD panaudojimo sausumos kariuomenès daliniuose sureguliavimo“ (Regelung des Einsatzes der Sicherheitspolizei und des SD im Verbände des Heeres $)^{88}$. Isakyme buvo nustatyta, kad sausumos pajëgų operatyvinëje erdvëje „ypatingų užduočių“ vykdymui veiks „,saugumo policijos sonderkomandos“.

\footnotetext{
85 T. Szarota, U progu zagłady. Zajścia antyżydowskie i pogromy w okupowanej Europie. Warszawa, 2000, s. $158-159$.

86 Gimè 1884-04-01 Kirchenlamitze. Karo tarnybą pradèjo 1912-08. Nuo 1935-04-01 - pulkininkas leitenantas, nuo 1937-10-01 - pulkininkas, nuo 1940-08-01 - generolas majoras, nuo 1942-04-01 - generolas leitenantas, nuo 1943-08- 01 - artilerijos generolas. 1940-08-01-194407-23 - sausumos pajègų generalinio štabo generalinis intendantas. Ramus ir objektyvus žmogus, nors gana temperamentingas. 1944-07-23 nusižudè.

87 J. Litan, Ostatni z „Zeppelina“, Warszwa, 1962, s. 76.

${ }^{88}$ Der deutsche Überfall auf die Sowjetunion. Frankfurt a. Main, 1991, s. 41.
} 
Buvo apibrèžtos bendradarbiavimo formos tarp Vermachto ir SS fronto rajonuose ir užnugaryje. $1941 \mathrm{~m}$. birželio mėn. RSHA susitarė su OKW, kad, jei kils karas su Sovietų Sąjunga, už saugumo policijos ir SD operatyvinių grupių aprūpinimą bei transportą bus atsakinga kariuomenė.

Tų pačių metų gegužès mėnesị Saxe įvyko slapta konferencija, kurioje dalyvavo 120 operatyvinių grupių ir komandų vadovų bei aukštas pareigas užimančių karininkų. Joje R. Haidrichas visiems susirinkusiems įteikè instrukcijas, kaip reikia elgtis karo atveju Rytuose. Už visų operatyvinių grupių komplektavimą buvo atsakingas RSHA I valdybos viršininkas SS brigadefiureris Bruno Heinrichas Štrekenbachas (Bruno Heinrich Streckenbach) ${ }^{89}$. Kadru atranka į šias grupes buvo labai kruopšti, atsižvelgiant ị kiekvieno kandidato moralines ir psichologines savybes. Grupių gretose vyravo griežta disciplina. SS reichsfiureris $\mathrm{H}$. Himmleris paskubejo viešai deklaruoti, kad atleidžia EG narius nuo atsakomybės ir prisiima ją visą sau. B. Štrekenbacho nurodymu jau sukomplektuoti specialus SS daliniai buvo apmokyti Prečo (Pretsch) (Saksonija) pasienio bei saugumo policijos sportinio lavinimo mokykloje prie Elbès netoli Torgau ir Diuben miestelyje (viršininkas SS štandartenfiureris Herbertas Edleris fon Daniels).

1941 m. birželio 17 d. RSHA konferencijų saleje (Prinz-Albrecht-Strasse 8) i̇vyko labai svarbus operatyvinių grupių vadovybės pasitarimas. Pranešimus perskaitė R. Haidrichas, B. Štrekenbachas, gestapo viršininkas H. Miuleris, URM atstovas ir kiti. Kaip teigia daugybe šią temą rašančių autorių, saugumo policijos ir SD operatyvinių grupių vadai gavo žodinį SS reichsfiurerio H. Himlerio nurodymą naikinti užimtoje Sovietų Sajungos teritorijoje komunistų veikejjus, žydus, čigonus, psichinius ligonius ir asocialius asmenis. Iki šiolei nėra rastas joks dokumentas, kuris būtų iki 1941 m. birželio 22 d.,

\footnotetext{
${ }^{89}$ Gimė 1902-02-07 Hamburge. Gavo universitetinị ekonominị išsilavinimą, mokejjo anglų bei prancūzu kalbas. Nuo 1930-12-01 - NSDAP narys (Nr. 489972), nuo 1931-08-31 - SS narys (Nr. 14713). Nuo 1933 m. - Hamburgo policijos viršininkas. 1939-01-30 apdovanotas NSDAP auksiniu ženkleliu. 1939-08-1939-11-20 - I Einsatzgrupès Lenkijoje vadas. 1939-11-20-1940 - saugumo policijos ir saugumo tarnybos Krokuvoje viršininkas. Nuo 1941-11-09 - SS grupenfiureris ir policijos bei Waffen-SS generolas leitenantas. 1940-10-10 apdovanotas II klasès Geležinio kryžiaus ordinu, o 1943-07-15 - I klasès Geležinio kryžiaus ordinu. 1943-12-15 apdovanotas Vokiečių aukso kryžiumi. Vyriausiosios Reicho saugumo valdybos I (personalo) valdybos viršininkas. Latvių SS legiono 19-osios divizijos vadas. 1944-08-17 apdovanotas Geležinio kryžiaus Riterio kryžiumi, 1945-01-16 apdovanotas „Ažuolo lapais“ prie Geležinio kryžiaus Riterio kryžiaus. H. Himmleris apdovanojo ji SS Garbès špaga ir SS „Mirties galvos“ žiedu. Nuo 1945-05-20 buvo rusų nelaisveje. 1952-02-18 karo tribunolo nuteistas 25 metus kalèti stovyklose. 1955-03-10 paleistas ị Vakarų Vokietiją. Mirè 1977-10-28 Hamburge.
} 
kuriame butų pateiktos instrukcijos operatyvinėms grupėms, kaip ir ką jos turi veikti Sovietų Sajungos teritorijoje: arba jų nebuvo, arba jų nepavyko išsaugoti karo ugnyje. Tik jau prasidejus karui su Sovietų Sajunga, $1941 \mathrm{~m}$. liepos 2 d., R. Haidrichas savo visiškai slaptame cirkuliare nubrěžè EG uždavinius, kurių tarpe artimiausias buvo „pacifikuoti naujai užimtas teritorijas“. Saugumo policijos ir SD operatyvinès grupès ir komandos privalëjo:

- užimti ir apieškoti partines ir teisèsaugos patalpas bei karinių dalinių štabus;

- užimti įstaigas, turinčias archyvus bei kartotekas;

- užnugario rajonuose negailestingai kovoti su visais antivokiškais ekscesais;

- informuoti vokiečių armijų užnugario vadus apie padètị jiems pavaldžiuose rajonuose ${ }^{90}$.

Be šio „inteligentiško“ darbo, SS padaliniams teko atlikti ir ne visai malonų darbą - „likviduoti išvardintus asmenis:

- kominterno bendradarbius, ir visus profesionalius komunistinius veikèjus;

- aukščiausios ir vidutinès grandies, taip pat aktyviausius žemesniosios grandies darbuotojus partijoje, Centro Komitete, apygardų ir rajonų komitetuose;

- liaudies komisarus;

- žydus - partijos narius ir dirbančius valstybinejje tarnyboje, taip pat kitus radikalius asmenis (diversantus, sabotuotojus, propagandistus, snaiperius, žudikus, padegejjus ir pan.) $)^{\text {“91 }}$.

I ieškomų ir skirtų likviduoti sąrašą buvo įrašyti ir prokomunistiškai nusiteikę etniniai vokiečiai ${ }^{92}$. Toliau šiame dokumente rašoma, kad „, $<\ldots>$ jeigu atskirais atvejais jie (išvardyti asmenys - P. S.) nėra reikalingi politiniais ar ūkiniais tikslais, kurie turi ypatingą reikšmę tolimesniems veiksmams saugumo srityje arba padètų atstatyti užimtų sričių ūkị. Ypač reikia atkreipti dẻmesị ị tai, kad nelikviduoti ūkinių, sajunginių ir prekybinių korporacijų, jeigu nèra asmenų, galinčių suteikti kompetentingą informaciją “93. Šiai užduočiai igyvendinti kiekviena operatyvinè grupe turèjo „Ypatingą

\footnotetext{
90 С. Г. Чуев, Спецслужбы III Рейха. Книга II, Санкт-Петербург, 2003, с. 24.

91 G. Deschner, Reinhard Heydrich namiestnik władzy totalitarnej, Warszawa, 2000, s. 185.

92 G. Williamson, Gwardia Adolfa Hitlera, Warszawa, 1995, s. 125.

93 T. Szarota, U progu zagłady. Zajścia antyżydowskie i pogromy w okupowanej Europie. Warszawa, 2000, s. $214-215$.
} 
paieškos knygą Sovietų Sajungai“, taip pat „Informacinį lapą gyvenamajai vietai nustatyti“. Operatyvinei grupei „A“ buvo išduotas informacinis leidinys „Baltijos šalys“ su visų didesnių miestų detaliais planais.

Didžiausią entuziazmą ruošiant specialias SD

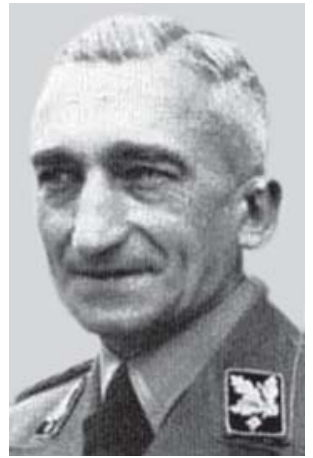

Operatyvinès grupès „B“" vadas SS gruppenfiureris A. Nebè operatyvines grupes savo funkcijoms atlikti parode saugumo policijos ir SD vadovas R. Haidrichas. Tačiau steigdamas operatyvines grupes jis susidūrè su tam tikrais sunkumais, kurių pagrindinis buvo aukštų RSHA pareigūnų atviras nenoras vykdyti ne visai karišką užduotị. Nei O. Olendorfas ${ }^{94}$, nei W. Štalekeris, nei V. Šelenbergas (W. Schellenberg), nei B. Štrekenbachas (B. Streckenbach), nei H. Miuleris nesutiko savo noru vykti ị Rytų fronto užnugarị. Tik vienintelis kriminalinès policijos viršininkas Arturas Nebè (Arthur Nebe) pasisiūlè savanoriu ${ }^{95}$.

Ar galima buvo nesutikti stoti ị specialius dalinius? Manau, tai buvo labai sunku atlikti, nes tuoj pat atsirasdavo nepaklusnumo problema. Sunku yra įsivaizduoti nesubordinaciją grynai vokiškoje aplinkoje, kurioje disciplinos tradicija buvo visados labai smarkiai įsišaknijusi. Tai ypač akivaizdu buvo nacionalinio socializmo laikais, kuris primesdavo visiems, o ypač priesaikos saistomiems esesininkams, atsisakyti visiškos individualybès. Tarptautiniame Niurnbergo procese į SS ir SD organizacijų gynejjo Liudvigo Babelio klausimą, ar galėjo EG narys pasipriešinti vadovybès įsakymų vykdymui, O. Olendorfas atsakè, kad negalejo, nes po to lauktų karinis teismas ir tam tikras nuosprendis ${ }^{96}$, o jei nepaklusnumo faktas atsitiktų fronte, nelaimèlis

\footnotetext{
94 Otto Ohlendorf - gimè 1907-02-04 Hoheneggelsen. Nuo 1925-05-28 NSDAP narys (bilieto Nr. 6531) ir SS narys (bilieto Nr. 880). Baige Gottingeno universitetą. Nuo 1935 skyriaus viršininkas Reicho ekonomikos ministerijoje. 1936-07-09 SS hauptšturmfiureris. 1936-09-27 perejo i SD ir paskirtas III valdybos viršininku. 1937-04-20 SS šturmbannfiureris. 1941-06-1942-07 operatyvinès grupès „D“ viršininkas. 1941-11-09 SS oberfiureris. 1942-07 grižo ị Berlyną. Reicho ekonomikos ministerijos Planavimo valdybos Ministerialdirektor ir jaunesnysis valstybès sekretorius. 1944-11-09 SS grupenfiureris ir policijos generolas leitenantas. Apdovanotas NSDAP auksiniu ženkleliu, SS reichsfiurerio Garbès špaga ir SS žiedu „Mirties galva“. 1945-05 Vakaru armijų suimtas ir 1948-04-10 nuteistas mirties bausme pakariant. Pakartas 1951-01-08 Landsberg kalejime (Bavarija).

95 Buvo numatytas policijos vadovu Maskvoje.

96 J. Heydecker, J. Leeb, Trzecia Rzesza w świetle Norymbergi. Bilans tysiąca lat, Warszawa, 1979 , s. 441.
} 
tučtuojau būtų nuteistas mirties bausme ${ }^{97}$. Vokietija yra šalis, kurioje duotas isakymas yra šventas reikalas. Reikia nepamiršti, kad pradinè, labai griežta atranka buvo jau esančiose formacijose (ivvairios policijos rūšys, Waffen SS ir kt.), kur mobilizacija buvo paremta gan griežtais reikalavimais. Nepriemimas kurio nors pareigūno ị EG gretas buvo greičiau komplektuojančiojo asmens sprendimas, nei paties kandidato atsisakymas. Pasipriešinimas tapti EG nariu pareigūnui grėsdavo prasta pabaiga. Galima drąsiai daryti išvadą, kad kurio nors pareigūno ịtraukimas į EG gretas buvo atliekamas tam tikra tvarka. Be to, atsižvelgiant ị ne visai aukštą pragyvenimo lygi prieškario Vokietijoje, nereikètų atmesti finansinio faktoriaus: kiekvienas operatyvinès grupès narys gaudavo gan nemažą uždarbị. Todèl eilinių savanorių vykdytojų tikrai netrūko.

1941 m. gegužès 30 d. R. Haidrichas pasirašè potvarkị, kuriuo likvidavo arba sustabde keleto gestapo ir saugumo policijos padalinių veiklą, o kitų pažemino padètị iki karo pabaigos ${ }^{98}$, bei sumažino pareigybių skaičių. Be to, ị SD struktūras pradèta priiminėti moteris ${ }^{99}$. Ši reorganizacija ịsigaliojo

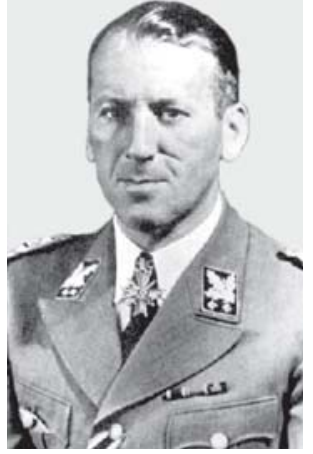

Po R. Heydricho žūties RSHA vadovu tapo advokatas SS obergruppenfiureris E. Kaltenbruneris nuo $1941 \mathrm{~m}$. liepos $1 \mathrm{~d}$. ir sudare efektingą prielaidą likviduoti kadrų trūkumą besikuriančiose SD operatyvinèse grupėse. Po didelių vargų R. Haidrichui pavyko sukomplektuoti reikiamą žmonių skaičių, tačiau vèliau dauguma jų visomis išgalèmis stengèsi ištrūkti iš šios struktūros ir grižti ị Vokietiją. Anglų autorius E. Krankšovas (E. Crankshaw), pasiremdamas Tarptautinio Niurnbergo proceso medžiaga, teigia, kad kai kurių RSHA valdybų vadovų buvimas SD gretose, kol jie vadovavo operatyvinèms grupèms, buvo suspenduotas ${ }^{100}$.

Operatyvinių grupių veikla tęsèsi dar 1943 - 1944 m. SS obergrupenfiureriui R. Haidrichui žuvus, jo ipėdinis SS obergrupenfiureris Ernstas Kaltenbruneris (Ernst Kaltenbrunner) perèmè organizaciją, jau mokančią vykdyti visas svar-

\footnotetext{
${ }^{97}$ Michel Moracchini, Les troupes speciales d'Hitler, 2001, s. 52.

98 Biuletyn głównej komisji badania zbrodni hitlerowskich w Polsce, tom XXIII, Warszawa, 1971, s. 19.

99 A. Ramme, Służba bezpieczeństwa SS, Warszawa, 1975, s. 220.

${ }^{100}$ E. Crankshaw, Gestapo - narzędzie tyranii, Warszawa, 1960, s. 157.
} 
biausias akcijas, kuriomis palaikoma tvarka valstybėje. RSHA septynios valdybos griežtai apibrèžtomis funkcijomis sudarè Vokietijos politinès valdžios branduolį. 1943 m. RSHA IV valdybos (gestapo) IV D skyrius pasipildė nauja sekcija - IV D 5 (užimtos teritorijos Rytuose). Analogiškos reformos ivvyko ir RSHA III valdyboje, kur III D skyrius buvo papildytas sekcija „Užimtos teritorijos Rytuose“"101. Artejjant karo pabaigai, RSHA vadovo funkcijos plètėsi: nuo 1944 m. rudens A. Hitlerio ịsakymu H. Himleris peremė muitinių kontrolę ir perdavė ją saugumo policijos vadui, kuris papildomai tapo pasienio muito apsaugos vadu (Zollgrenzschutz). 1944 metais RSHA buvo evakuota į Teresiną, kur ir sulaukè karo pabaigos.

\section{SD Lietuvos generalinėje srityje}

Iš trijų Pabaltijo valstybių Lietuvai, atsižvelgiant ị jos strateginę padėtị, vokiečiu specialiosios tarnybos skyrè didžiausią dėmesị. Lietuvos autonominis Klaipėdos kraštas nuo 1923 m. pastoviai buvo vokiečių dẻmesio centre. Dar ankstyvais 1933 m., kai vokiečių tauta patikejjo savo likimą A. Hitlerio vadovaujamai NSDAP, šios partijos užsienio politikos vadovas A. Rosenbergas vasario ménesi parengė koncepciją, pagal kurią perversmą Klaipėdoje siejo su valstybiniu perversmu Kaune, ịvykdytu kariuomenę remiant „Geležinio Vilko" organizacijai, kuri tuo metu bendradarbiavo su vokiečių nacionalsocialistų darbininkų partijos įstaiga užsienio politikos klausimais (Aussenpolitisches Amt der Nationalsozialistischen Deutschen Arbeiterpartei-APA), vadovaujama NSDAP reichsleiterio A. Rosenbergo. Nuo pat pirmų isteigimo dienų ši organizacija aktyviai veikè ir Lietuvoje. Šiems vokiečių planams skaudų smūgi sudavė 1934-1935 m. teismo procesas Kaune, kur tarp 126 kaltinamųų buvo teisiama nemažai SD agentų. Itampos tarp Lietuvos ir Vokietijos viršūnė buvo A. Hitlerio kalba Reichstage 1935 m. gegužès 21 d., kurioje buvo grasinama Lietuvai ir atsisakoma bet kokių derybų ir bendradarbiavimo. İsteigtas $S D$ Oberabschnitt Nord-Ost bei Kionigsbergo Gestapo ịstaiga bendradarbiavo, savo veiklą nukreipę prieš Lietuvą, siekiant atgauti Trečiajam Reichui Klaipedos kraštą ${ }^{102}$. SD ir Gestapas lygiagrečiai su Vokietijos ginkluotuju pajègu žvalgyba ir kontržvalgyba - Abveru (Abwehr) globojo naujai ịkurtą nacistinę organizaciją Memeldeutscher Kulturverband Klaipėdoje (vadovai SS štandar-

101 K. Grünberg, SS - czarna gwardia Hitlera, Warszawa, 1975, s. 167.

102 M. Cygański, SS w polityce zagranicznej III Rzeszy w latach 1934 - 1945, Warszawa, Wroclaw, 1975, s. 182. 
tenfiureris dr. Ernstas Noimanas, Reichertas, Kosmanas ir SA šturmbanfiureris Vilis Bertuleitas). Visa ši įvairiapusė veikla buvo apvainikuota skaudžia netektimi Lietuvai - 1939 m. Lietuva prarado Klaipėdą.

Buvęs vyriausiasis karo komendantas Lietuvoje 1941 - 1944 m. gen. mjr. E. Justas savo pokariniuose parodymuose sovietų tardymo organams rašè: „Kai 1938 m. buvau karo atašè, įsižiūrẻjau, su kokiu įžūlumu dirbo SD Nachrichtendienst Lietuvoje“"103. Be to, generolas savo parodymuose teigè, kad „lietuviai tarnautojai jau prieš karą ir prieš Raud. Armijai okupuojant $<\ldots>$ Lietuvą buvo SD agentai arba gestapo šnipai“104. Ypač aktyviai Lietuvos kryptimi dirbo vokiečių karinès žvalgybos organas „,Abwehrstelle Königsberg" (iki 1939 m. rugsėjo mèn. vadovavo mjr. fon Davancas (von Davanz), po jo iki 1942 m. kovo mèn. - plk. Johanas Kipas (Johann Kip) ${ }^{105}$. Juos skatino Abvero vadovas adm. V. Kanaris, ne kartą akcentuodamas, kad būtina žaisti Vilniaus korta, siekiant stumti lietuvius ị konfliktą su Lenkija. Šioje srityje ypač aktyvus buvo vokiečių žvalgybos ryšininkas su Lietuvos žvalgyba kpt. Joachimas Kleinas (Joachim Klein). Jis metodiškai kūrẻ savo

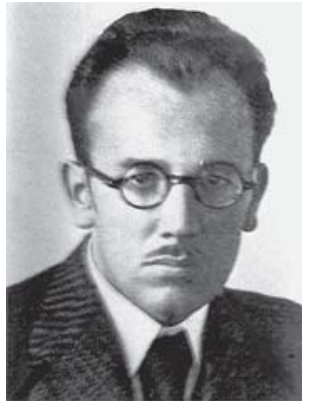

Lietuvos valstybès saugumo departamento direktorius Augustinas Povilaitis agentūrą Lietuvoje ir noriai padejjo lietuvių žvalgybai dirbti ir prieš Sovietų Sajungą, ir prieš Lenkiją. Kaune J. Kleinas įsteigė Abvero poskyrị (kodinis pavadinimas ,Likog“), kuriam vadovavo kartu su kontržvalgybinio darbo specialistu ltn. Augustu Riesenu (August Riesen). Savo ruožtu lietuvių žvalgybininkai noriai dalijosi surinkta informacija su J. Kleinu, o šis ją perduodavo koduotais pranešimais Abvero skyriaus rezidentui Rytų Prūsijoje mjr. Justui. Lenkijos kontržvalgybos raportuose randame daug pranešimų apie lietuvių bendradarbiavimą su Vokietijos specialiosiomis tarnybomis. Dar iki 1939 m. kovo mèn. Abvero poskyris buvo isteigtas Klaipedoje ir artimai bendradarbiavo su lietuvių karo apygardos štabu.

Nuo 1937 m. beveik visi SS Vyriausiosios saugumo tarnybos valdybos padaliniai pradejo kaupti informaciją, kurios gali prireikti galimo karo

103 Lietuviai okupantų vokiečių akimis. Generolo Emilio Justo parodymai. Laisvès kovų archyvas, t. 9, Kaunas, 1993, p. 146.

104 Ten pat, p. 138.

105 Jo nuotrauka yra LCVA, f. 56, b. 763, 1. 80. 
metu. Papildant agentų raportus, SD siekè registruoti ir vertinti visus pasirodančius rimtesnius straipsnius apie Lietuvą bei ją supančias valstybes. Jau 1938 m. spalio 7 d. Vyriausiosios SD valdybos (SD-Hauptamt) II valdybos pareigūnai gavo nurodymus planuojant užduotis prioritetinę reikšmę skirti Pabaltijo kraštams. Todèl Vyriausiosios SD valdybos II valdyba 1939 m. birželio 29 d. raštu kreipèsi ị Trečiojo Reicho užsienio reikalų ministrą J. fon Ribentropą (von Ribbentropp) skirti piniginių lèšu profašistinei Augustino Voldemaro organizacijai „Geležinis vilkas“ paremti (Woldemaras-Leute) ${ }^{106}$.

SD agentų rezidentūrai Lietuvoje vadovavo oficialus SD pareigūnas. Pas jị suplaukdavo visi agentų pranešimai, kuriuos persiųsdavo ị RSHA. Duomenų persiuntimas buvo atliekamas paštu, naudojant simpatinị rašalą, per kurjerius vokiečių laivais bei per pasiuntinybę Kaune. Rusų autorius F. Sergejevas savo knygoje teigia, kad iki 1941 m. gegužès mèn. Lietuvos teritorijoje NKVD organai likvidavo 75 Abvero ir SD agentūrines grupes ${ }^{107}$.

Kai Lietuvą okupavo Sovietų Sajunga, vokiečių žvalgyba nenutraukẻ ryšiu su lietuviais. $1940 \mathrm{~m}$. liepos mėn. viename Suomijos pusiasalyje buvo isteigtas specialus žvalgybos mokymo centras, kuriame buvo mokomi ir ruošiami agentai lietuviai ${ }^{108}$. Kilus karui, jie privalèjo atlikti daug svarbių užduočių, tarp jų užimti geležinkelio tunelius bei tiltus netoli Vilniaus. Abvero specialaus pulko „Brandenburg“1-ojo bataliono viena kuopa, vadovaujama barono ltn. Adriano fon Folkersamo (Adrian von Foelkersam) ${ }^{109}$, buvo sukomplektuota daugiausiai iš lietuvių.

Yra kai kurių duomenų, kad be priešiškų veiksmų prieš Lietuvą ir netekus dalies savo teritorijos, Europoje jau vykstant Antrajam pasauliniam karui ir Lietuvą okupavus bolševikams, kai kurie Lietuvos politiniai veikėjai užmezgè ryšius su Vokietijos saugumo tarnybomis dar iki vokiečių - rusų karo pradžios. Deja, dẻl autentiškų dokumentų stokos mažai šiandien galime pateikti aplinkybių dẻl lietuvių derybų su RSHA atstovais Berlyne. 1941 m. balandžio 18 d. Lietuvių aktyvistų fronto vadovas plk. Kazys Škirpa apsilankẻ saugumo policijos būstinèje Berlyne, „kur įvyko pasikalbėjimas su

106 A. Ramme, Służba bezpieczeństwa SS, Warszawa, 1975, s. 103, 106.

107 Ф. Сергеев, Тайные операции нацистской разведки (1933-1945), Москва, 1991, с. 158.

108 St. Lewicki, Szpiedzy Kajzera i Hitlera, Warszawa, 1978, s. 295.

109 Gimė 1918. Kilęs iš senos Pabaltijo vokiečiu šeimos. Už kovinius nuopelnus 1942-09-14 apdovanotas Geležinio kryžiaus Riterio kryžiumi. Žuvo 1945-01-21 turèdamas SS šturmbannfiurerio laipsni. 
Lietuva susijusiais klausimais"110. Aukštas vokiečių saugumo pareigūnas, atsakingas už ryšius su lietuviais, SS šturmbannfiureris dr. Heincas Grefẻ pasiūle K. Škirpai neakcentuoti Lietuvos nepriklausomybès reikalavimo, nes vykstant karui ir jam pasibaigus, kol nesistabilizuos padétis Europoje, visiška mažų tautų nepriklausomybė yra negalima ${ }^{111}$.

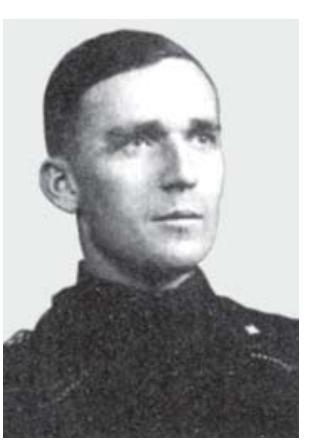

Vokiečių saugumo policijos pareigūnas, atsakingas už ryšius su lietuviais, SS sturmbannfiureris dr. H. Grefé

Teisès mokslų daktaras Heincas Grefé (Heinz Gräfe) ${ }^{112}$ buvo viena idomiausių ir paslaptingiausių vokiečių saugumo policijos figūrų, veikusi lemtingais Lietuvai 1939 - 1940 m. ìvykių užkulisiuose. Vokiečių saugumo policijos pareigūno, atsakingo už ryšius su lietuviais, H. Grefès konfidencialūs pasimatymai su Lietuvoje veikusiais vokiečių agentais vykdavo Kaune, A. Černiauskienès viešbutyje, greta geležinkelio stoties. Jame H. Grefé apsistodavo tik kelioms valandoms ir tą pačią dieną išvykdavo atgal ị Rytų Prūsiją. $1940 \mathrm{~m}$. birželio 16 d. RSHA vadovybès nurodymu jam teko internuoti Prezidentą A. Smetoną su palydovais, pabėgusiais iš Lietuvos ir atsiradusiais Eitkūnuose, bei rūpintis jų saugumu. Tačiau

110 J. Bulavas, Vokiškụjų fašistų okupacinis Lietuvos valdymas (1941-1944 m.), Vilnius, 1969, p. $40-41$.

111 L. Truska, Lietuva bolševiku ir nacių smurto metais, Lietuvos rytas, 199301 16, Nr. 9.

112 Gimè 1908-07-15 Leipcigo knygų prekybininko šeimoje. Nuo 1928 studijavo teisę Leipcigo universitete ir įsitrauke i Vokietijos nacionalsocialistų studentų sajungos veiklą. Nuo 193312-21 S narys, Nr. 107213, Oberregierungsrat. 1935 buvo paskirtas Kylio saugumo policijos viršininko pavaduotoju. Tiktai 1937-05-01 tapo NSDAP nariu, bilieto Nr. 3959575. Nuo 193710 iki 1940-01 Tilžès (dabar Sovetskas - P. S.) gestapo viršininkas, kartu eidamas Gumbinès (dabar Gusevas - P. S.) SS kovinio padalinio vado pareigas, o vẻliau visos Rytų Prūsijos gestapo vadas. 1939-09 Lenkijoje vadovavo SS V-os operatyvinès grupès 1-am operatyviniam būriui. 1939-04-20 jam suteiktas SS šturmbannfiurerio laipsnis. Netrukus buvo pervestas i RSHA ir nuo 1941-04-01 skiriamas VI valdybos (SD) C grupès viršininku (ši grupe kuravo Rytų valstybes, tame tarpe ir Baltijos šalis). Ši postą užėmė iki 1942-03. Užmezgęs kontaktus su Lietuvos saugumo departamento vadovybe, bendradarbiavo atskleidžiant įvairių tarptautinių aferistų ir kontrabandininkų veiklą. Laisvai kalbejjo rusiškai, mokèjo anglų bei prancūzų kalbas ir neblogai mokejo lietuviškai. Nuo 1942-03 saugumo policijos vadovaujančio sąstato mokyklos Berlyne viršininkas. 1943-04-20 tapo SS Oberšturmbannfiureriu. Buvo apdovanotas II klasès Geležiniu Kryžiumi. 1944-01-25 žuvo lèktuvo katastrofoje. 1944-04-15 po mirties jam už ypatingus nuopelnus suteiktas SS štandartenfiurerio laipsnis. Buvęs sovietų užsienio žvalgybos vadovas Pavelas Sudoplatovas teigia, kad Antrojo pasaulinio karo išvakarėse H. Grefé Kaune buvo užverbuotas Sovietų Sajungos specialiụjų tarnybų. 
jo pastangos padèti savo geriems pažįstamiems - vidaus reikalų ministrui Kaziui Skučui ir Valstybės saugumo departamento direktoriui Augustinui Povilaičiui - pereiti Lietuvos ir Vokietijos sieną baigèsi nesèkme.

Šioje vietoje verta priminti, kad iki karo tarp Sovietų Sajungos ir Vokietijos galiojo tarptautinis generalinis susitarimas tarp Sovietų Sajungos Vidaus reikalų liaudies komisariato Valstybès saugumo vyriausiosios valdybos ir Trečiojo Reicho NSDAP Vyriausiosios saugumo valdybos, pasirašytas 1938 m. lapkričio 11 d. Maskvoje tarp 1 rango valstybès saugumo komisaro Lavrentijaus Berijos ir Ketvirtos valdybos (Gestapo) viršininko SS brigadefiurerio H. Miulerio. Susitarimo pirmame paragrafe abi pusės įsipareigojo negailestingai kovoti su bendrais priešais, trečiame paragrafe - atlikti bendras žvalgybines ir kontržvalgybines operacijas. Ketvirtame paragrafe konstatuojama, kad, susiklosčius situacijai, kai iškils grèsmė kuriai nors susitariančiai valstybei, jos informuos viena kitą ir imsis abiem pusėms naudingų priemonių pašalinti iškilusią nepalankią situaciją. Čia galima iškelti prielaidą, kad, Lietuvą okupavus Sovietų Sajungai, Vokietijos specialiosios tarnybos nutare pamokyti nesukalbamus lietuvius NKVD rankomis, pateikdami Maskvai informaciją apie augantị Lietuvoje antibolševikinị pogrindị. Gal tuo galima paaiškinti pagausėjusius lietuvių patriotų areštus?

$1941 \mathrm{~m}$. birželio $14 \mathrm{~d}$. Vokietijos saugumo tar-

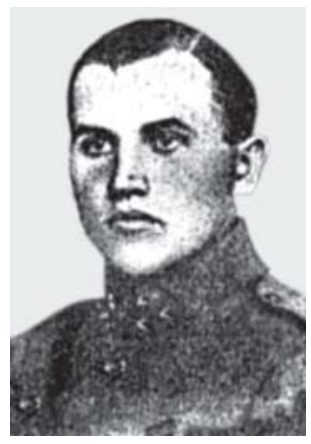

Lietuvių aktyvistų fronto vadovas pulkininkas Kazys Škirpa nybos pakartotinai pareikalavo iš Lietuvos pasiuntinio ir igalioto ministro Berlyne K. Škirpos, kad, kilus karui, nebūtų skelbiama Lietuvos nepriklausomybe ir sudaroma vyriausybė. Vokietijos valdžios ultimatyvų reikalavimą K. Škirpai pakartojo buvęs nepriklausomos Lietuvos valstybès saugumo darbuotojas S. Čenkus, kuris būdamas emigracijoje Vokietijoje palaikè glaudžius ryšius su savo kolegomis gestape ir SD.

Besiruošiant karui su Sovietų Sajunga buvo panaudota visa bendradarbiavimo su Lietuvos žvalgyba medžiaga. $1941 \mathrm{~m}$. birželio 22 d. vokiečių Wehrmachtas staiga ir netikètai pradejo igyvendinti „Barbarossos“ planą. Buvo suformuotos trys armijų grupuotès: „Šiaure““ (Nord), „Centras“ (Mitte) ir „Pietūs“ (Süd). Paskui kariuomenę traukẻ jau sukomplektuoti vokiečių civilinès administracijos organų padaliniai bei SS struktūros. 
Birželio mèn. sukilimas Lietuvoje palengvino Vermachto žygị ị Rytus. Lietuvių pastangos atkurti Lietuvos nepriklausomybę prasidejjus Vokietijos - SSSR karui, iš SD pusés žiūrint, vokiečiams negalejo patikti. Birželio 25 d. K. Škirpa buvo iškviestas į RSHA pasiaiškinti, kodèl paskelbta Lietuvos Nepriklausomybė, sudaryta Vyriausybè, o plk. K. Škirpa tapo jos Ministru Pirmininku. Čia pat jam buvo paskirtas namų areštas, kuriame jis prabuvo iki liepos 19 d. ${ }^{113}$ Vokiečių saugumo policijos pareigūnas Lietuvoje $S S$ šturmbannfiureris dr. H. Grefė reikalavo, kad Laikinoji Lietuvos vyriausybė (toliau LLV) išsiskirstytų, jog ta Vyriausybė paskelbta be susitarimo su Vo-

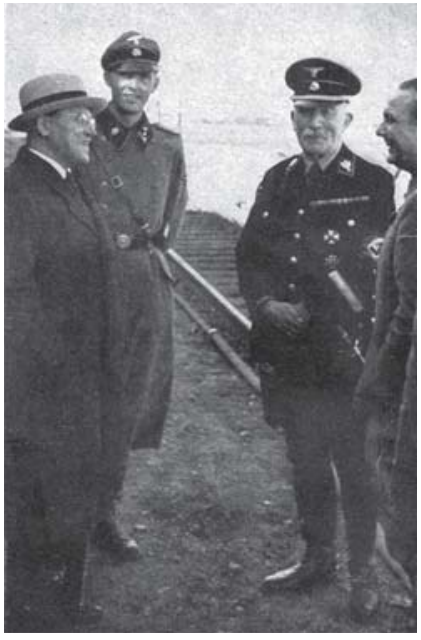

Lietuvos pasiuntinys ir igaliotasis ministras Berlyne

K. Škirpa su SS brigadefiureriu dr. Evaldu fon Massov kietijos institucijomis ir todèl negali būti pripažinta. LLV tokị dr. H. Grefés reikalavimą atmetė ir nutarè savo veiklą tęsti. Kai kurios vokiečių žinybos (Reicho užimtų Rytų kraštų ministerija, URM, Vyriausioji ginkluotoju pajėgu vadovybé (Oberkommando der Wehrmacht - OKW), abwehras ir SD) lietuviu pasitikejjimo tarybos (Vertrauensrat), kurią planavo įsteigti likvidavus LLV, priešakyje ketino pastatyti div. gen. Stasi Raštikį, kuris, jų manymu, laikèsi krikščioniškų demokratinių pažiūrų. Jau birželio $27 \mathrm{~d}$. lietuvių generolas lẻktuvu kartu su operatyvinès grupès „A“ štabu buvo pristatytas ị Kauną. Naujuoju derybininku su nepaklusniaisiais lietuviais Berlynas paskyrè irgi su saugomo policija susijusi esesininką $S S$ šturmbanfiurerį P. B. Kleistą (Peter Bruno Kleist) ${ }^{114}$, kuris liepos 19 d. atvyko ị Kauną. Kai LLV atsi-

113 A. Gražiūnas, Lietuva dviejų okupacijų replèse: 1940-1944. Vilnius, 1996. p. 142.

114 Gime 1904-01-29. Daktaras, nuo 1931 NSDAP narys (bilieto Nr. 1277679), SS narys (bilieto Nr. 203045), 1934-1935 lenkų ir Baltijos valstybių referato vadovas, J. fon Ribentropo biuro (NSDAP Dienststelle von Ribbentrop) pareigūnas; 1940 m. Užsienio reikalų ministerijos departamento viršininkas, paskui perejjo ị A. Rosenbergo vadovaujamą Užimtų Rytų sričių ministeriją. Germanizavimo akcijos Lietuvoje, Latvijoje ir Estijoje vadovas, visų užimtų Rytų sričių suvokietinimo ekspertas. Nuo 1941-04-20 - SS šturmbannfiureris, apdovanotas SS reichsfiurerio Garbès špaga ir SS žiedu „Mirties galva“. Lietuvos teritorijoje vadovavo specialiai sukurtos smogiamosios A grupès daliniams. 1943 - ministerijos regentas, Užimtų Rytų sričių ministerijos I/2 skyriaus (Ostland) vadovas. Po karo - neofašistinès organizacijos „Pasipriešinimo akcija“ vadovas. Knygu „Tarp Hitlerio ir Stalino“ (1950) ir „Europos tragedija“ (1972) autorius. 
sakè pati nutraukti savo veiklą, SD ėmèsi kitos taktikos: skaldyti vieningą lietuvių nusiteikimą pačių lietuvių rankomis.

Vokiečiams rūpejjo likviduoti Lietuvių aktyvistų frontą, kuris buvo ịvykdęs antibolševikinị sukilimą, organizavęs Laikinają Vyriausybę ir toliau organizavo lietuvių patriotinę visuomenę. Vèliau, $1941 \mathrm{~m}$. rugsèjo 21 d., vokiečių saugumo policijos ir SD pareigūnai užėmė LAF štabą Kaune. Vienas iš jo vadovų L. Prapuolenis buvo suimtas.

Užimti Pabaltiji buvo pavesta vienai iš trijų pagrindinių karinių grupuočių - armijų grupei „Šiaure““ (Nord) (16-oji ir 18-oji armijos bei 4-oji tanku grupè), vadovaujamai gen. feldmaršalo Vilhelmo fon Leebo (Wilhelm Ritter von Leeb) $)^{115}$. Jai buvo priskirta viena iš septynių paruoštų veikti Rytuose SS operatyvinių grupių, pažymėtų simboliu „A“ (SS Einsatzgruppe A) (vadas SS brigadefiureris ir policijos gen. mjr. teisès dr. F. V. Štalekeris ${ }^{116}$. Grupè pradejo savo veiklą 16 armijos (vadas gen. plk. Ernstas Bušas (Ernst Busch)) užnugaryje šiaurinèje fronto dalyje - Pabaltijyje, taip pat ir Lietuvoje. Be kitu funkcijų, grupei buvo pavesta aktyviai iggvendinti agentūrines kontržvalgybines priemones armijų grupès „Šiaure““ užnugaryje, taip pat vykdyti užfrontès žvalgybą - visų pirma Leningrade. Šị darbą paprastai atlikdavo grupé, susi-

115 Gimė 1876-09-05 Passau. Karo tarnybą pradejo 1895-07-16. Pirmojo pasaulinio karo metais apdovanotas II ir I klasès Geležinio kryžiaus ordinu. Nuo 1925-02-01 - pulkininkas, nuo 1929-02-01 - generolas majoras, nuo 1930-02-01 - generolas leitenantas. 1930-02-01-1933-1001 - 7-osios pėstininkų divizijos vadas. Nuo 1934-01-01 - artilerijos generolas, nuo 1938-11-01 - generolas pulkininkas. 1939-08-26-1941-05 - armijų grupès „C“ vadas. 1940-06-24 apdovanotas Riterio kryžiumi prie Geležinio kryžiaus ordino. Nuo 1940-07-19 - generolas feldmaršalas. 1941-05-1942 01-16 armijų grupès „Šiauré“ vadas. Mirè 1956-04-29 Hohenschwangau.

116 Prie kiekvienos įžengusios ị Sovietų Sajungos teritoriją armijų grupès vadovybės buvo priskirtas saugumo policijos ir SD vado igaliotinis, kuriam buvo pavaldi po vieną SS operatyvinę grupę (SS Einsatzgruppe) - atitinkama pažymėtos simboliais „A“, „B“, „C“. Savo laiku Austrijoje ir Čekoslovakijoje veikusios operatyvinès grupès turejjo savo vardą, Lenkijoje buvo žymimos romènišku skaičiumi, o Sovietų Sajungoje - raidiniu indeksu. Operatyvinè grupe „D“ buvo priskirta prie 11 armijos, veikiančios Rusijos pietuose. Be paminètų keturių grupių dar buvo „Ypatingos paskirties grupe “ (Einsatzgruppe zur besonderer Verwendung) (veike vakarų Baltarusijoje, vadas $S S$ brigadefiureris E. Schöngarth), operatyvinè grupe „G“ (veikè Juodosios jūros rajone, vadas SS štandartenfiureris J. Kreuzer) ir Einsatzgruppe Reinhardt (veikè vakarų Ukrainoje - Galicijoje, vadas SS brigadefiureris E. Schöngarth). Kiekvienai operatyvinei grupei vadovavo aukšto rango bei pareigų - ne žemesnio kaip valdybos viršininko - RSHA karininkas, turintis SS generolo laipsnị. Visos operatyvinès grupès organizaciniais bei taktiniais klausimais buvo pavaldžios operatyvinès grupès „D“ (SS Einsatzgruppe D) viršininkui, 36 metų teisès ir ekonomikos mokslų daktarui, saugumo policijos ir SD vado igaliotiniui prie 11 armijos vadovybès, SS brigadefiureriui O. Olendorfui, kuris lygiagrečiai buvo RSHA III valdybos viršininkas. Pažymėtina, kad į Sovietų Sajungą ižžngusios saugumo policijos ir SD operatyvinès grupès, palyginus su ankstesnèmis, veikẻ ilgus metus, o jų specifinès užduotys buvo daug radikalesnès. 


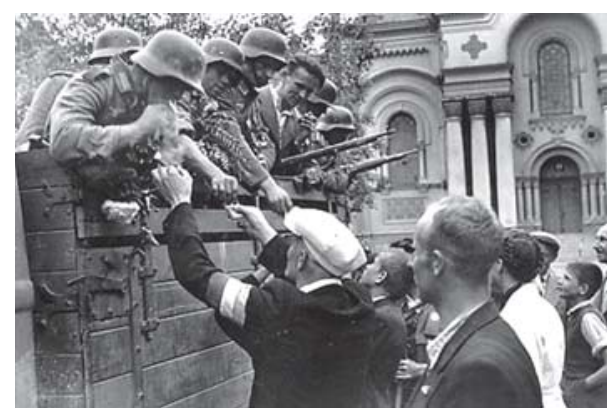

Lietuvos gyventojai su džiaugsmu sutinka vokiečių wehrmachto karius (1941-06-26)

dedanti iš vieno karininko, 2-3 puskarininkių, kelių kareivių SS rezervistų bei kelių vietinių vertèjų. Ši Kionigsberge ịsteigta operatyvine grupé veikè taip pat šiaurineje Rusijoje (Pskovas, Novgorodas), o jos štabas nuo $1941 \mathrm{~m}$. spalio 7 d. buvo dislokuotas Krasnogvardejske (Gatčina) prie Leningrado. Atsižvelgiant ị teritorijos dydị (beveik pusė Vakarų Europos), grupès vadui $S S$ brigadefiureriui

dr. F. V. Štalekeriui geresniam ir operatyvesniam pareigų atlikimui bei inspekcinėms kelionėms buvo priskirtas specialus ryšio lèktuvas „Storch“.

Operatyvinès grupès „A“ vadas SS brigadefiureris dr. F. V. Štalekeris privalejo reguliariai teikti ataskaitas apie savo grupès veiklą armijų grupès „Šiaurè“ Žvalgybos viršininkui plk. Fridrichui Jeseliui (Friedrich Jeesel). F. Jeselis savo parodymuose Tarptautiniame Niurnbergo procese teigé, kad F. V. Štalekerio raportuose būdavo žvalgybinio pobūdžio bei žmonių nuotaikas atspindinti informacija, bet né žodžio apie kitą operatyvinès grupés veiklą ${ }^{117}$. Tik atskirais atvejais jiems teko dalyvauti koviniuose veiksmuose. $1941 \mathrm{~m}$. pab. parengtuose pranešimuose apie grupès veiklą randame informacijos apie vis aktyvejjantị dalyvavimą kovojant su sovietiniais partizanais. Būtent dẻl šios priežasties ị operatyvinès grupès sudèti buvo paskirtas tam tikras skaičius Waffen $S S^{118}$ karininkų. Pagal savo sudètį operatyvinè grupè „A“ daugiau buvo panaši ị štabą (būsimoji policinè administracija) negu ị kovinị padalinị. Operatyvinès grupès vadovybès sudètyje buvo vienas SS brigadefiureris, penki SS šturmbannfiureriai ir vienas kriminalkomisaras ${ }^{119}$. Grupès štabas (viršininkas SS štandartenfiureris Walteris Potzeltas (Walter Potzelt ${ }^{120}$ )

117 J. Litan, Ostatni z „Zeppelina“, Warszwa, 1962, s. 76.

118 SS koviniai daliniai.

119 Gestapo pareiginis laipsnis.

120 Gime 1903-07-16 Chemnitz. Banko tarnautojas. 1930-06-01 NSDAP narys Nr.266433, 193011-22 SS narys Nr. 3838. 1932-08-24 SS šturmfiureris, 1933-11-09 SS oberšturmfiureris, 1934-0420 SS šturmbannfiureris, 1934-07-04 SS oberšturmbannfiureris, 1936-04-20 SS štandartenfiureris. 1939-09 Einsatzgruppe VI vado pavaduotojas. 1942-04-20 - 1942-07-01 Einsatzgruppe A štabo narys, viršininkas. Apdovanotas II klasès Geležiniu kryžiumi. 1944 RSHA. 
1941 m. rudenị savo sudètyje turèjo adjutantūrą (adjutantas SS oberšturmfiureris Horstas Eichleris (Horst Eichler) ${ }^{121}$ ) bei penkis skyrius.

Prancūzų autorius Mišelis Morašinis, kuriam 1950 m. pavyko susipažinti su operatyvinių grupių teismo proceso Nr. 9 Niurnberge archyvine medžiaga, pateikè šị operatyvinès grupès „A“ vokiečių pareigūnų pasiskirstymą pagal organizacinę priklausomybę ${ }^{122}$ :

Lentelė nr. 1 „Operatyvinès grupės „A“ vokiečių pareigūnų pasiskirstymas pagal organizacinę priklausomybę“"

\begin{tabular}{|c|c|}
\hline Waffen SS & 360 \\
Ordnungspolizei & 145 \\
Gestapo & 90 \\
Kripo & 72 \\
SD & 66 \\
Nenustatyti & 48 \\
\hline Iš viso: & 781 \\
\hline
\end{tabular}

Tuo tarpu šios Einsatzgruppe $A$ pareigūnų tautinè sudètis, to paties autoriaus duomenimis, $1941 \mathrm{~m}$. lapkričio mèn. buvo tokia:

Lentelẻ nr. 2 „Operatyvinès grupès „A“ pareigūnų tautinė sudètis“

\begin{tabular}{|c|c|}
\hline Vokiečiai (austrai) $^{*}$ & 781 \\
Lietuviai*** $^{*}$ & 36 \\
Latviai $^{\text {Rusai }}$ & 22 \\
Lenkai & 21 \\
Suomiai & 19 \\
Estai & 18 \\
Kiti & 9 \\
\hline Iš viso: & 25 \\
\hline
\end{tabular}

* Austrai sudare trečdalį EG personalo. P. Johnson, Žydụ istorija, Aidai, 1999, p. 725.

** Manyčiau, kad tai dalis Vilniaus SD ypatingojo būrio, kuris nebuvo pavaldus lietuviškai administracijai.

121 Gimė 1910-07-19 Dancige. 1931-02-01 NSDAP narys (Nr.469670), 1933-03-01 SS narys (Nr. 66309). Mokejjo anglų kalbą. Už nuopelnus apdovanotas II klasės Geležiniu kryžiumi.

122 Michel Moracchini, Les troupes speciales d'Hitler, 2001, s. 28. 


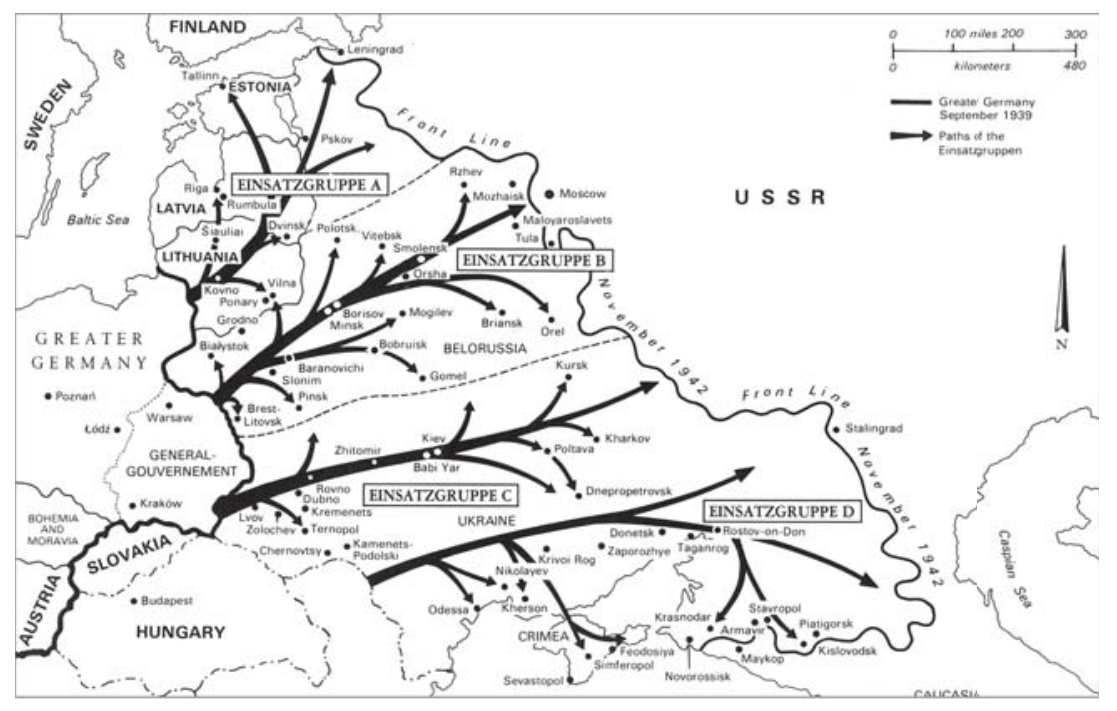

Operatyvinių grupių žygių maršrutai

Būtina pažymėti, kad karo pradžioje gana didelę operatyvinių grupių personalo dali sudarè kitataučiai ${ }^{123}$. Tai paaiškinama tuo, kad dalis užimtų teritorijų vietinių gyventojų buvo pasiruošę tarnauti vokiečiams komplektuodami savo atstovais pagalbinius padalinius. Tarp operatyvinès grupès „A“ karininkų, kaip nurodo M. Morašinis, nebuvo lietuvių, kaip ir kitų tautybių atstovų. Ne visada vokiečiai pripažino lietuvių karininkus karininkais ir jiems reikdavo tenkintis eilinio arba puskarininkio padètimi. Bendradarbiavimo su vokiečiais reiškinys buvo labai įvairus, priklausomai nuo laiko ir vietos, bet gan ženklus. Per laiką kitataučių skaičius vis mažèjo - daugiausiai dèl dezertyravimo ${ }^{124}$.

SS Einsatzgruppe A su ịvairiais struktūriniais pasikeitimais veikè Pabaltijyje bei Rusijos šiaurèje tolimame fronto užnugaryje (kitos grupès veikè iš karto už fronto linijos karinès administracijos zonoje) daugiau nei 3 m. 1942 m. pavasari prie šios operatyvinès grupès, kaip ir prie kitų, veikusių Rytuose, buvo îsteigta fronto komanda „Cepelin“ (Sonderkommando

123 Уничтожение евреев СССР в годы немецкой оккупации, ЯД ВА-ШЕМ, Иерусалим, 1992, с. 10.

124 Vokiečių saugumo policijos ir SD vado ataskaitos RSHA vertimo ị lietuvių kalbą nuorašas, LCVA, f. R-1399, ap. 1, b. 61, 1. 15. 
unternehmen Zeppelin), kurios tikslas - rinkti žvalgybinę informaciją apie Raudonają Armiją bei organizuoti diversinę veiklą SSSR teritorijoje. „Cepelino" komandos steigimo iniciatyva priklause $S S$ šturmbanfiureriui dr. H. Grefei. 1943 m. vasario mèn. buvo atlikta operatyvinès grupės „A“ reorganizacija: buvo paskirti nauji operatyvinių būrių (SS Einsatzkommando) ir ypatingų būrių (SS Sonderkommando) vadai, kad nutrauktų jų funkcijų susipynimą su saugumo policijos ir SD vado funkcijomis, ypač rajonuose, jau seniai nutolusiuose nuo fronto. Operatyvinè grupe „A“ galutinai buvo išformuota 1944 m. spalio 17 d., o jos nariai buvo paskirstyti ị ịvairius Waffen-SS dalinius.

$1941 \mathrm{~m}$. gruodžio $1 \mathrm{~d}$. buvo ịsteigta vyriausioji SD apygarda „Ostland“ (Leitabschnitt SD Ostland), kuri turejo tris SD apygardas (Abschnitt SD) - Estija, Latvija ir Lietuva. Iki 1942 m. kovo mėn. visiems vokiečių saugumo policijos ir SD padaliniams Ostlande vadovavo operatyvinès grupès „A“ viršininkas. Vẻliau buvo įsteigta vyresniojo saugumo policijos ir SD vado Ostlande pareigybė. Jo žinion perẻjo operatyviniai (SS Einsatzkommando) ir ypatingieji būriai (SS Sonderkommando) bei teritoriniai saugumo policijos ir SD padaliniai. Jam pavaldžiose saugumo policijos gretose buvo 800 žmonių ${ }^{125}$. Be to, jam pavaldūs buvo apsauginiai batalionai, mobilūs policijos daliniai, pagalbinés policijos padaliniai bei tarnybos: techninès pagalbos, NSKK $^{126}$, priešgaisrinė apsauga, vietiniai apsauginiai ir policiniai daliniai - vietiné policija ir žandarmerija. 1942 m. jo pavaldumui iš Abvero buvo perduota slaptoji lauko policija - GFP ${ }^{127}$. Teritoriniai saugumo policijos ir SD padaliniai buvo viena ịstaiga, vykdanti Gestapo, policijos ir SD funkcijas. Šios įstaigos steigimas vyko operatyvinių grupių turimų struktūrų bazèje. Vyresniojo saugumo policijos ir SD vado Ostlande štabas Rygoje buvo nedidelis ir turẻjo iki 25 pareigūnų ir tarnautojų. Štabas vykdẻ jiems pavaldžių saugumo policijos ir SD įstaigų vadovavimą ir atsiskaite už jų veiklą RSHA. Štabo vidinė struktūra beveik atitiko RSHA struktūrą:

1-asis skyrius - kadrų atranka, paruošimas ir komplektavimas;

2-asis skyrius - materialinis-techninis aprūpinimas;

3-asis skyrius - saugumo tarnyba (SD);

125 J. Gdański, Cudzoziemskie jednostki policyjne w służbie Trzeciej Rzeszy. Przyczynek do historii Schutzmannschaften. Pamięć i sprawiedliwość. Biuletyn głównej Komisji Badania Zbrodni przeciwko Narodowi Polskiemu Instytutu Pamięci Narodowej. XL, Warszawa, 1997 - 1998, s. 356.

126 Nationalsozialistische Kraftwagenkorps - Nacionalsocialistinis vairuotojų korpusas.

127 Geheime Feldpolizei - slaptoji lauko policija. 
4-asis skyrius - Gestapas;

5-asis skyrius - kriminalinè policija (kripo).

Kiekvienas skyrius buvo padalytas į tam tikrus skyrius ir poskyrius. Štabo personalas dirbo ne tik popierinị darbą, bet aktyviai dalyvavo tiriant bylas bei tardant sulaikytuosius.

Pirmieji ị vakarinius Lietuvos rajonus 1941 m. birželio 22 d. įvažiavo SD operatyvinès grupès „A“ Einsatzkommando „Tilsit“ kariai, vadovaujami SS šturmbanfiurerio Hanso Joachimo Biomès (Hans-Joachim Böhme). Jų kelias ejjo per Tauragę, Kudirkos Naumiestị, Virbalị, Kybartus, Vilkaviškį, Švėkšną. Birželio 25 d. rytą kartu su savo operatyvinès grupès „A“ priešakiniu būriu (Vorkommando) į Lietuvos laikinają sostinę Kauną įženge SS brigadefiureris ir policijos gen. mjr. dr. F. V. Štalekeris. Atvykusios vokiečių saugumo policijos ir SD operatyvinès grupès vadas stengèsi sukoordinuoti ginkluotus lietuvių būrius, atsikuriančią lietuvių saugumo ir viešają policiją, tvarkyti jų veiklą norima vokiečiams linkme. Šios grupès operatyvinis būrys 3/A ypač aktyviai èmé komanduoti vietiniams ginkluotiems lietuvių būriams. Būrių vadai gavo ịgaliojimus bei tarnybinius pažymejjimus in blanco, kuriuose buvo parašas: „Dr. Stahlecker SS-Brigadeführer und Chef der Einsatzgruppe A der

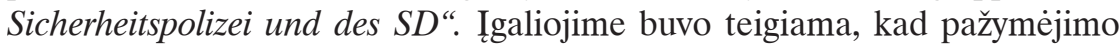
savininkas veikia vokiečių saugumo policijos ir saugumo tarnybos igaliotas ir visi prašomi suteikti jam reikiamą pagalbą. Pažymejjimo savininkui buvo garantuota asmeninė Štalekerio globa, suteikta teisẻ būti gatvèje komendanto valandos metu bei turèti su savimi šaunamaji ginklą ${ }^{128}$. Tačiau Vermachto junginių vadovybė Lietuvoje kategoriškai pasisakẻ prieš tokių dokumentų in blanco išdavimą ir jie per laiką nebebuvo išduodami.

Karo su Sovietų Sajungą pradžioje ị Lietuvos pietinę teritoriją buvo įžengę dar vienos saugumo policijos ir SD operatyvinės grupés, pažymėtos raidiniu simboliu „B“ ir priskirtos prie armijų grupès „Centras“, padaliniai. Jau birželio 23 d. operatyvinè grupe „B“"129 atvyko ị Poznanę (Lenkija), kad kitos dienos ryte žygiuotų i Varšuvą. Vykdant RSHA nurodymą, buvo užmegztas ryšis su armijų grupès „Centras“ (,,Mitte“) vadovybe bei šios grupès užnugario zonos nr. 102 vadu. Po suderinimo grupés ypatingasis būrys 7a (Sonderkom-

128 K. Stang, Kollaboration und Massenmord. Die litauische Hilfspolizei, das Rollkommando Hamann und die Ermordung der litauischen Juden, Frankfurt am Main, 1996, p. 116.

129 Iki 1941-07-11 ši SS brigadefiurerio Arthuro Nebe vadovaujama operatyvinè grupe turejo indeksą „C“ arba pakaitalą „III“. 07-11 operatyvinè grupe „B“ gavo indeksą „C“. - “Ereignismeldungen UdSSR”, 1941-07-09, Nr. 17. 
mando 7a, vadas SS oberšturmbannfiureris Valteris Blumė (Walter Blume)130 birželio 26 d. buvo priskirtas prie 9-osios armijos ir per Rytų Prūsiją ketino keliu nr. 4 žygiuoti ị Vilnių. Tačiau gavo operatyvinès grupès vado nurodymą pakeisti žygiavimo kryptị ị pietus ir žygiuoti ị Minską, kur ir atvyko liepos $4 \mathrm{~d}$. Operatyvinis būrys 9 (Einsatzkommando 9, vadas SS oberšturmbannfiureris dr. Alfredas Filbertas (Alfred Filbert) ${ }^{131}$ birželio 29 d. atvyko ị Vilnių ir čia išbuvo iki rugpjūčio $9 \mathrm{~d}$. Jis Vilniuje iš Vermachto perèmé vietos savivaldybės sukurtą lietuvių policiją ${ }^{132}$. Atsakingais už tvarkos palaikymą paskirti policijos pareigūnai ir lietuvių aktyvistų apsaugos būrys. Visiems gyventojams buvo ịsakyta paklusti ne tik vokiečių karinès administracijos, bet ir jos paskirtų vietinių savivaldos institucijų, taip pat lietuvių pagalbinès policijos įsakymams, juos vykdyti. Vokiečių karinès administracijos viršininkai uždraudẻ vietos valdžios institucijoms (lietuvių policijai) suimti gyventojus ne žydus, jei nėra iš anksto gauto vokiečių karinių ar policinių ịstaigų raštiško sutikimo ${ }^{133}$. Vilniaus miesto ir srities piliečių komitetas buvo informuotas, kad „, <...> vokiečiu $<\ldots>$ saugumo policijos ir SD veiksmai turi pirmenybę prieš Lietuvos teismo įstaigų veiksmus“134. Rugpjūčio 9 d. operatyvinis būrys 9/B išvyko ị Pskovą.

Galiausiai 1941 m. rugpjūčio 9 d. Vilnių perémė operatyvinio būrio 3/ A padalinys (Teilkommando 3/A), vadovaujamas SS Oberšturmfiurerio Ericho Volfo (Erich Wolff), o vèliau SS Hauptšturmfiurerio Hermano Gertho

130 Gime 1906-07-23 Dortmunde Martene. Studijavo Erlangeno, Bonos, Jenos, Miunsterio universitete, teisès daktaras. Nuo 1933-05-01 - NSDAP narys (bilieto Nr. 3282505). Iki 1934 dirbo Vestfalijos SA Ic grupés referentu. 1935-04-11 įstojo ị SS (bilieto Nr. 267224). 1935, turédamas SS unteršturmfiurerio laipsnị, priimtas ị SD, paskui ejjo įvairias pareigas gestapo Dortmundo, Hales ir Hanoverio įstaigose. 1941 RSHA personalo skyriaus pareigūnas. 1941-07-01 - 09-07 Vilniaus ypatingojo būrio 7a vadovas. Nuo 1941-11-09 SS štandartenfiureris. Nuo 194208 Zalcburgo saugumo policijos ir SD komendantas, o nuo 1943-09 vokiečių saugumo policijos ir SD vadas Graikijoje, vèliau tos pačios pareigos Diuseldorfe. Apdovanotas I klasės Geležiniu kryžiumi. 1948-04-10 Niurnbergo procese Nr. 9 nuteistas mirties bausme, bet 1951-01 bausmė sumažinta iki 25 metų kalèjimo. 1953 m. išlaisvintas. Mirè 1977 Dortmunde.

${ }^{131}$ Gimè 1905-09-08. Daktaras, NSDAP narys (bilieto Nr.1321414), SS narys (bilieto Nr.44552), SS oberšturmbannfiureris, iki 1941-08-02 operatyvinio būrio 9/B (SS - Einsatzkommando 9/B) iš Einsatzgruppe $B$ vadas Vilniuje, vėliau išvyko į Pskovą. Po karo, 1962-06-22 Berlyne nuteistas 10 metų kalèti.

132 Vitzhakas Aradas teigia, kad tuo metu EK-9 buvo 150 lietuvių policininkų. V. Arad, Gheto in flames. The struggle and destruction of the Jews in Vilno in the holocaust, Jerusalem, 1980, s. 347.

133 Vokiečiu karinès administracijos viršininko gen. mjr. Volfgango fon Ditfurtho (Wolfgango von Ditfurtho) 1941-07-16 įsakymo vertimo ị lietuvių kalbą nuorašas, LCVA, f. R - 1436, ap. 1, b. $38,1.81$.

134 Ten pat, f. R-685, ap. B. 2, 1. 16. 


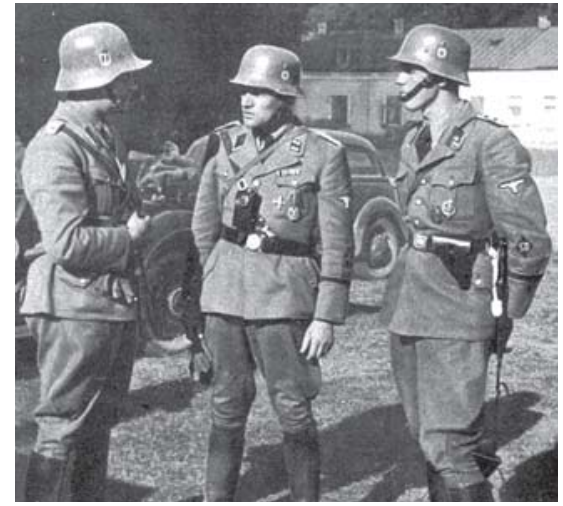

Operatyvinès grupės karininkai aptaria kovos situaciją

(Hermann Artur Gerth) $^{135}$. Šiame padalinyje tarnavo apie 40 pareigūnų. Apie 1942 m. vasario mèn., Teilkommando 3/A buvo pavadintas vokiečiu saugumo policijos ir SD Vilniaus skyriumi. Jam iš pat pradžių vadovavo minètasis $\mathrm{H}$. Gerthas, o po jo SS Oberšturmfiureris Rolfas Neugebaueris (Rudolf Neugebauer $)^{136}$ ir Augustas Miuleris (August Müller) ${ }^{137}$. Šio skyriaus organizacinę struktūrą, pasiremdamas A. Ramès studija apie SS saugumo tarnybą, gan smulkiai yra pateikęs A. Bubnys ${ }^{138}$.

Birželio 28 dieną i Kauną atvyko kitas operatyvinès grupès „A“ padalinys - ypatingasis būrys $1 \mathrm{~b}$ (Sonderkommando $1 \mathrm{~b}$ ), vadovaujamas $S S$ oberšturmbannfiurerio dr. Ericho Ehrlingerio (Erich Ehrlinger) ${ }^{139}$, kuris trumpai

135 Gime 1901 Berlyne. 1941-1942 Vilniaus miesto saugumo policijos ir SD skyriaus viršininkas. 136 Gime 1912-12-21. NSDAP narys (bilieto Nr. 1086615), SS narys (bilieto Nr. 266047), SS oberšturmfiureris, vokiečių saugumo policijos ir SD štabo Vilniuje IV skyriaus (gestapo) B poskyrio viršininkas. Nuo 1942-02 iki 1943-10 vokiečių saugumo policijos ir SD vadas Vilniuje. Pakeltas ị SS hauptšturmfiurerio laipsnị. Vẻliau perkeltas ị Kauną, į SD štabą Lietuvoje. Iš Lietuvos išvyko į Budapeštą. Pokarinis likimas autoriui nežinomas.

137 SS oberšturmfiureris, vokiečių saugumo policijos ir SD įstaigos Lietuvoje IV skyriaus (gestapo) viršininkas. Nuo 1943 m. - vokiečių saugumo policijos ir SD Vilniaus skyriaus viršininkas.

138 Stankeras P. Vokiečiu ir lietuvių saugumo policija (1941 - 1944), Genocidas ir rezistencija, 1997, Nr.1, p. 162-163; A. Bubnys, Vokiečių okupuota Lietuva (1941-1944), Vilnius, 1998, p. $79,83$.

139 Gimè 1910-10-14 Viurtemberge. Studijavo Kielio, Berlino, Tiubingeno universitetuose. Mokejjo anglų kalbą. Nuo 1931-04-15 NSDAP (Nr.541195) ir SA narys. Nuo 1935-06-22 SS narys (Nr.107493). 1935-07-01 SS unteršturmfiureris ir SD Vyriausiosios valdybos pareigūnas Berlyne. 1938-03-12 SS šturmbannfiureris. 1939 SS oberšturmbannfiureriu vadovavo Einsatzkommando IV Lenkijoje. 1940-04-12 - 08-14 tarnavo SS pulke „Adolf Hitler“ Vakaruose. 1941 pradžioje buvo V. Quislingo patareju Osle. Nuo 1941-03 darẻ puikią karjerą RSHA. 1941-06 - 1941-11 vadovavo Sonderkommando $1 b$. Nuo 1941-12-03 saugumo policijos ir SD vadas Baltarusijoje. 1943-08-28 - 1944-04 operatyvinès grupès „B“ vadas. Nuo 1944-04-01 SS štandartenfiureris ir RSHA I (kadrai) valdybos viršininkas, o po to tapo RSHA vadovo E. Kaltenbrunerio pavaduotoju. 1944-11-09 SS oberfiureris. Apdovanotas I klasės Geležiniu Kryžiumi. Karo pabaigoje persirengęs Vermachto puskarininkio uniforma, pasislèpé anglų karo belaisvių stovykloje. Tik 1958-12-09 patrauktas teisminėn atsakomybėn ir 1959 Liudvigsburge nuteistas 12 metų kalèti. 1963 dèl sveikatos būklès paleistas iš kalëjimo. Dirbo Volkswageno gamykloje. 
buvo aukščiausia vokiečių policinė valdžia mieste. Jau tą pačią dieną jo ìsakymu karo lauko komendantūra nuginklavo ir išformavo lietuvių sukilèlių būrius. Po derybų su Kauno miesto ir apskrities karo komendantu plk. K. Bobeliu (dr. E. Ehrlingerio pritarimo ir pagalbos dèka), iš jų buvo pradètas formuoti ir vèliau apginkluotas lietuvių pagalbinès policijos batalionas „Polizeihilfsbataillon Kaunas“, lietuviškai vadinamas Tautinès darbo Apsaugos 1-asis batalionas ${ }^{140}$. Batalione buvo penkios kuopos, iš kurių dvi buvo sukomplektuotos iš „Geležinio vilko“ narių. Būtent šios dvi kuopos buvo priskirtos prie SS ypatingojo būrio $1 \mathrm{~b}^{141}$. Lenkų autorius R. Korab-Žebrykas ši Heinricho Hamano ${ }^{142}$ padalini i ivardija kaip ,,Sonderkommando 3/A“ ir teigia, kad jame šalia $8-10$ esesininkų buvo apie 80 lietuvių aktyvistų ${ }^{143}$. Operatyviné grupe „A“ savo $1941 \mathrm{~m}$. liepos 5 d. raporte informavo R. Haidrichą, kad Kaune, nepriklausomai nuo įsteigtų iš vietinių gyventojų pagalbinès policijos dalinių, dar papildomai ịsteigti du padaliniai ypatingoms užduotims ${ }^{144}$. Vyriausiosios Reicho saugumo valdybos pagal 1941 metų liepos 6 dienos operatyvinès grupès raportą parengtame „Pranešime apie ịvykius Sovietų Sajungoje“ (,Ereignismeldungen UdSSR“) aprašoma susidariusi situacija Kaune: „<..> Partizanai ir su jais susiję žmonès vokiečių lauko komendanto įsakymu buvo nuginkluoti. Pagalbinès policijos padalinys, susidedantis iš penkių kuopų, buvo įsteigtas iš patikimų partizanų. Dvi iš tų kuopų buvo priskirtos prie SS Einsatzkommando <... > "145.

Po kelių dienų buvimo Panevėžyje, birželio 29 d., i Kauną atvyko operatyvinès grupès „A“ operatyvinis būrys 3/A (Einsatzkommando 3/A), kuriam vadovavo $S S$ štandartenfiureris Karlas Jegeris (Karl Jäger), ir vokiečiai galiausiai valdžią Kaune paėmè į savo rankas. Ltn. B. Norkus, iškviestas i K. Jegerio įstaigą, gavo nurodymą savo veiksmus derinti su gestapo vadovu SS hauptšturmfiureriu dr. Heinrichu Šmitcu (Heinrich Schmitz) ${ }^{146}$ arba SS

140 LCVA, f. R-1444, ap. 1, b. 8, 1. 35.

141 Ereignismeldungen UdSSR, Nr.14 vom 6.07.41.

142 A. Damušis Hamanui suteikia vardą „Guenther“. A. Damušis, Lietuvos gyventojų aukos ir nuostoliai antrojo pasaulinio karo ir pokario (1940-1959) metais, Kaunas, 1991, p. 73.

${ }^{143}$ R. Korab-Żebryk , Biała księga w obronie Armii Krajowej na Wileńszczyżnie, Lublin, 1991, s. 12.

144 T. Szarota, U progu zagłady. Zajścia antyżydowskie i pogromy w okupowanej Europie. Warszawa, 2000, s. 260-261.

145 Ten pat, p. 261.

${ }^{146}$ Gimè 1890-12-26. Daktaras, NSDAP narys (bilieto Nr. 2895358), SS narys (bilieto Nr. 141696), SS hauptšturmfiureris, visų vokiečių saugumo policijos ir SD vadų Lietuvoje (K. Jegerio, W. Fuchso, H. Biome) pavaduotojas, šios tarnybos įstaigos Kaune IV skyriaus (gestapo) viršininkas. 


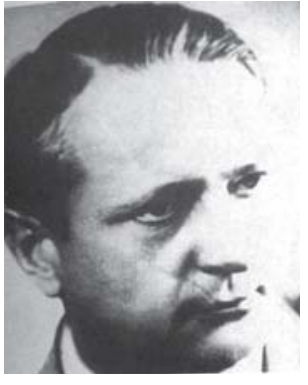

Gestapo vadovas Lietuvoje SS hauptsturmfiureris dr.

H. Šmitcas

oberšturmfiureriu Hamanu. Dar tris dienas vokiečių saugumo policijai ir SD mieste vadovavo SS oberšturmbannfiureris dr. E. Ehrlingeris. Tačiau jau 1941 $\mathrm{m}$. liepos $2 \mathrm{~d}$. operatyvinis būrys 3/A perèmé saugumo policijos funkcijas Lietuvoje. K. Jegeris tapo saugumo policijos ir saugumo tarnybos (SD) vadu Lietuvos generalinejje srityje.

Anglų autorius E. Krankšovas (E. Crankshaw) teigia, kad operatyvinio būrio, veikiančio Lietuvoje, žymią dali sudare lietuviai ${ }^{147}$ ir jie buvo labai aktyvūs. Jam pritariantis rusų autorius M. Krysinas rašo, kad tarnybai prie operatyvinès grupès A operatyvinio būrio 3/A (Einsatzkommando 3/A) „savanoriškai stojo 1150 lietuvių, vadovaujamų Antano Iškausko“"148. Tuo tarpu vokiečių saugumo policijos ir SD (tuo pačiu operatyvinių grupių) vadų $1941 \mathrm{~m}$. liepos $11 \mathrm{~d}$. raporte Nr. 19 Vyriausiajai Reicho saugumo valdybai „Pranešimai apie įvykius Sovietų Sajungoje“ (,Ereignismeldungen UdSSR“) yra teigiama, kad Einsatzgruppe A sudètyje aktyviai veikia 250 žmonių lietuvių Sonderkommando ${ }^{149}$. Po dviejų dienų parengtame raporte jau kalbama apie 150-ies lietuvių būrị, veikiantị Einsatzgruppe $A$ sudètyje ${ }^{150}$.

A. Bubnys rašo, kad $1941 \mathrm{~m}$. rugsèjo 23 d. operatyvinis būrys 3/A buvo reorganizuotas ị vokiečiu saugumo policijos ir SD vado Lietuvoje istaigą ${ }^{151}$. Nuo 1941 m. liepos 15 d. iki 1942 m. balandžio 24 d. oficialiuose dokumentuose buvo vartojamas dvejopas šiu pareigu pavadinimas: „Saugumo policijos ir SD vadas, operatyvinis būrys 3“. Vèliau buvo vartojama tik pirmoji pavadinimo dalis. Pagrindinès operatyvinio būrio 3/A pajègos bei štabas po trumpo užtrukimo Panevėžyje apsistojo Kaune, o ị Vilnių, Šiaulius bei kitus Lietuvos miestus išvyko kiti šio būrio padaliniai. Būrio sudètyje buvo 141 žmogus, tarp jų: 32 Waffen-SS kariai, 34 vairuotojai, 1 administracijos darbuotojas, 10 SD pareigūnų, 10 kriminalinès policijos pareigūnų, 29

147 E. Crankshaw, Gestapo - narzędzie tyranii, Warszawa, 1960, s. 191.

148 М.Ю. Крысин, Прибалтика между Сталиным и Гитлером, Москва, 2004, с. 139, 338.

149 Ereignismeldungen UdSSR, Nr.19 vom 11.07.41.

150 Ereignismeldungen UdSSR, Nr.21 vom 13.07.41.

151 A. Bubnys, Vokiečių okupuota Lietuva (1941-1944), Vilnius, 1998, p. 78. 
gestapo darbuotojai, 15 pagalbinès policijos narių, 1 tarnautoja (moteris), 8 vertejai, 1 radijo operatorius.

Saugumo policijos ir SD operatyvinès grupès (SS Einsatzgruppe) ir operatyviniai būriai (SS Einsatzkommando) ì nedidelius Lietuvos miestelius bei gyvenvietes nusiųsdavo mažesnius būrius, vadinamus SS Teilkommando. Tokie nedideli būriai turẻjo viršininką, 5 - 6 tardytojus, 2 raštvedžius, 4 - 5 vertejus, $4-5$ vairuotojus bei $6-8$ apsaugos policininkus. Ypatingieji būriai (SS Sonderkommando) prieš įžengdami ị miestelị ar kitą gyvenvietę iš savo sudèties suformuodavo priešakinị būrị (Vorkommando) svarbiems objektams - partiniams organams, NKVD valdyboms ir skyrių pastatams bei archyvams - užimti bei kitoms užduotims vykdyti.

Šiauliuose iki $1941 \mathrm{~m}$. spalio $1 \mathrm{~d}$. veikè operatyvinis būrys 2/A (vadas $S S$ šturmbannfiureris Rudolfas Batcas (Rudolf Batz) ${ }^{152}$ ). Netrukus jis buvo reorganizuotas ị vokiečių saugumo policijos ir SD Šiaulių skyrių ${ }^{153}$. R. Batcui išvykus i Latviją, spalio 2 d., Šiauliai perejo operatyvinio būrio 3/A padalinio žinion.

Karo pradžioje Lietuvos teritorijoje veikusios SD operatyvinès grupés „A“ kai kurie padaliniai nebuvo dideli: ${ }^{154}$

152 Gimè 1903-11-10 Langensalza. Baigè teisès studijas, dirbo advokatu. Nuo 1933 NSDAP narys (bilieto Nr.2955905), SS narys (bilieto Nr.272458). 1935-12 pradejo tarnybą SD. Nuo 1936-06-01 Breslau gestapo viršininko pavaduotojas. Nuo 1938-08-01 SS hauptsturmfiureris, Regierungsrat. 1940 SS sturmbannfiureris. 1940-1941 dirbo saugumo policijos ir SD vado istaigoje Olandijoje. 1941-06-01 - 1941-11-04 tarnavo EG „A“, buvo Einsatzkommando 2 vadas ir lygiagrečiai saugumo policijos ir SD vadas Latvijoje. 1942 Hanoverio Gestapo viršininkas. 194312 - 1945 SS štandartenfiureris ir saugumo policijos ir SD vadas Krokuvoje. 1961 nusižudè.

153 Šiaulių getas: kalinių sąrašai, 1942: almanacho „Žydų muziejus“ priedas, Vilnius, 2002, p. 28.

154 French L. MacLean, The Field Men. The SS Officers Who Led the Einsatzkommandos - the Nazi Mobile Killing Units, U.S.A., 1999, s. 13. 
Lentelė nr. 3 „SD operatyvinès grupès „A“ padalinių dydis“

\begin{tabular}{|l|c|c|c|c|}
\hline & $\begin{array}{c}\text { Sonderkom- } \\
\text { mando 1a }\end{array}$ & $\begin{array}{c}\text { Sonderkom- } \\
\text { mando 1b }\end{array}$ & $\begin{array}{c}\text { Einsatzkom- } \\
\text { mando 2 }\end{array}$ & $\begin{array}{c}\text { Einsatzkom- } \\
\text { mando 3 }\end{array}$ \\
\hline Waffen SS & 25 & 26 & 41 & 32 \\
Vairuotojai & 23 & 34 & 50 & 34 \\
Administracija & 3 & 2 & 4 & 1 \\
SD & 8 & 3 & 8 & 10 \\
Kripo & 11 & 6 & 13 & 10 \\
Gestapo & 18 & 12 & 26 & 29 \\
Pag. policija & 0 & 20 & 0 & 15 \\
Ordnungspolizei & 0 & 0 & 0 & 0 \\
Moterys & 1 & 0 & 4 & 1 \\
Tardytojai & 14 & 6 & 18 & 8 \\
Telegrafininkai & 0 & 0 & 3 & 0 \\
Radijo operat. & 2 & 1 & 3 & 1 \\
\hline \multicolumn{1}{|c|}{ Iš viso: } & 105 & 110 & 170 & 141 \\
\hline Iš jų karininkų: & 5 & 13 & 26 & 5 \\
\hline
\end{tabular}

1941 m. rugpjūčio mėn. operatyvinès grupès ir operatyvinių komandų, veikusių Ostlande ir Lietuvoje, vadus pasiekè rugpjūčio 24 d. Gestapo vadovo $\mathrm{H}$. Miulerio telegrafinis nurodymas, kad, atliekant prevencines akcijas, nukreiptas prieš komunistus ir žydus, nekreipti démesio į civilinių įstaigų galimą įsikišimą. Šis dokumentas atsirado kaip reakcija ị Ostlando reicho komisaro Hinricho Lozès (Hinrich Lohse) bandymus ${ }^{155}$ pristabdyti akcijas prieš komunistus ir žydus ${ }^{156}$.

Formaliai tik 1942 m. kovo mèn. buvo įsteigta vokiečių saugumo policijos ir SD (Sicherheitspolizei und Sicherheitsdienst - SD) vado Lietuvos generalineje srityje pareigybė (Kommandeur der Sicherheitspolizei und des $S D)$ bei įstaiga. Naujoji vokiečiu policijos įstaiga Lietuvoje gavo karo lauko pašto numerị $15641^{157}$. Šios įstaigos steigimas vyko operatyvinès grupès „A“ turimų struktūrų bazėje. İstaiga dislokavosi Kaune ir jos struktūra beveik atitiko RSHA struktūrą. Saugumo policijos ir SD vado pareigybė užimtoje teritorijoje atitiko saugumo policijos ir SD inspektoriaus (Inspekteur der Sicherheitspolizei und des SD) pareigybę Vokietijoje. Be savo

155 1941-07-27 H. Lohse parengė memorandumą „Elgesio su žydais Ostlande patarimai“, kuriame rekomendavo išnaudoti žydus darbe Reicho labui.

156 А. Зегер, Гестапо-Мюллер, Москва, 1997, с. 230-231.

157 V. Fugalevičius, Pašto antspaudai Lietuvoje, 1990, p. 239. 
aparato, saugumo policijos ir SD vadas turèjo žemesnius teritorinius organus: išorinius skyrius Aussendienststelle, apskričiu centruose Aussenstelle ir Zweigstelle bei punktus Blokstelle. Vokiečių saugumo policija ir saugumo tarnyba turèjo centrinę ịstaigą Kaune bei skyrius Vilniuje, Panevėžyje, Marijampoleje, Kretingoje ir Šiauliuose (Aussendienststelle Sipo und SD). Kituose miestuose ir miesteliuose buvo vadinamieji SD ir gestapo postai. Saugumo policijos ir SD skyrių vadovai atitinkamų apygardų komisarams nebuvo pavaldūs. Vokiečių saugumo policijos ir SD skyriuje Kaune 1943 m. gruodžio 1 d. dirbo 112 valdininkų, Vilniaus miesto skyriuje - 40 valdininkų, Šiaulių apygardoje - 7, Panevěžio - 6 valdininkai1 ${ }^{158}$. 1943-1944 m. centrinejje įstaigoje Kaune svarbiausi buvo šie skyriai: III - SD, IV - gestapas ir V - kriminalinè policija ${ }^{159}$. Vokiečiu saugumo policija ir SD Lietuvoje, turẻdama labai plačiai išsišakojusi savo padalinių tinklą, be kitų funkcijų, sẻkmingai vykdė RSHA direktyvą kontroliuoti vokiečių administracijos ir jos įstaigų veiklą.

Vokietijoje ir okupuotose teritorijose gestapo, kriminalinè policija ir SD formaliai veikẻ atskirai; užimtose rytų šalyse jų veiklos koordinacija buvo glaudesnè ir jie buvo pavaldūs ne tik RSHA vadovui, bet ir SS ir policijos vadui, esančiam administracijos aparato sudètyje. Lietuvos generalinėje srityje vokiečių kriminalinė policija veikẻ patarnaudama Gestapui, atlikdama pagalbines funkcijas. Vèliau, siekiant sudaryti kriminalinei policijai efektyvesnes veiklos sąlygas, jos funkcijos buvo plečiamos.

Ypatingą vietą šioje struktūroje užėmė gestapo skyrius, ypač jo sekcija IV A b, nagrinėjusi žydų klausimus. Ši sekcija dirbo labai savarankiškai, lyg nebūtų organizacinès struktūros sudètinè dalis. Faktiškai saugumo policijos ir SD vadas turẻjo minimalią valdžią šiam padaliniui ir menkai žinojo, ką veikia jos vadovas, dažniausiai turintis kpt. laipsni (SS-Hauptsturmführer). Šioje veiklos srityje buvo nustatytas konkretus tarnybinis pavaldumo kelias: Hitleris - Himleris - Haidrichas (Kaltenbruneris) - Miuleris - Eichmanas - ir toliau, aplenkiant SS ir policijos bei saugumo policijos ir SD vadus, - teritorinis SS šturmbanfiurerio Adolfo Eichmano atstovas, kuris iš tiesų turèjo neribotą valdžią bei igaliojimus.

Personalo poskyriui vadovavo ir pareigūnų tarnybos bylas savo seife saugojo pats saugumo policijos ir SD vadas. Naujų darbuotojų atranka buvo labai

158 A. Bubnys, „Vokiečių ir lietuvių saugumo policija (1941-1944)“, Genocidas ir rezistencija, 1997, Nr. 1, p. 166.

${ }^{159}$ Masinès žudynès Lietuvoje (1941-1944), Dokumentų rinkinys, I dalis, p. 327. 
kruopšti ir griežta, atsižvelgiant ị jų politinị lojalumą bei profesinius gabumus. Visi SD darbuotojai buvo padalyti ị dvi grupes: operatyviniai pareigūnai ir techniniai - ūkiniai administracijos tarnautojai. Antroje grupẻje žmonių skaičius buvo beveik dvigubai didesnis negu pirmoje, bet be jų sąžiningo ir kruopštaus darbo negalètų funkcionuoti ši svarbi vokiečių administracijos institucija. Dažnai čia darbą surasdavo vokiečiu pareigūnų žmonos. Svarbią vietą struktūroje užėmè specialaus pašto poskyris: saugumo policija nepatikėdavo savo slaptų siuntinių bendrai pašto tarnybai, vadinamai Vokiečių rytų paštu.

SD įstaigose Lietuvoje, kaip etatinių tarnautojų, dirbo nemažai 19401941 m. repatriantų, buvusių Lietuvos piliečių, dabar grịžusių atgal ị Lietuvą $^{160}$. Jie nesijautè eiliniais Lietuvos piliečiais, bet dejosi esą Herrenvolk - valdančios tautos atstovai.

Ostlando vyriausiojo saugumo policijos ir SD vado (Befehlshaber der Sicherheitspolizei und des SD Ostland/Riga, BdS Ostland/Riga), o lygiagrečiai Pabaltijyje veikusios operatyvinès grupès „A“ viršininko (Befehlshaber der Einsatzgruppe A) pareigas nuo 1941 m. birželio 22 d. iki 1944 m. spalio 17 d. vykde šie aukštieji vokiečių SS karininkai:

19410622 - 19420323 - SS brigadefiureris ir policijos gen. mjr. teisès dr. Francas Valteris Štalekeris (Franz Walter Stahlecker) ${ }^{161}$;

160 Ars Historica, Poznań, 1976, s. 783.

161 Gimè 1900-10-10 Sternenfelse (Austrija). 1918-09-21 - 1207 karinė tarnybą fronte. Po karo Tiuringijos universitete baigè teisès studijas ir tapo teisès mokslų daktaru (1927) bei valstybès tarejju. Nuo 1930-08-28 iki 1933-05-28 darbo biržos direktorius. Pirmą kartą NSDAP nariu buvo 1921/23 metais. Dar kartą juo tapo 1932-05-01 (bilieto Nr. 1069130, po naujo perregistravimo Nr. 3219015). Tuo pačiu metu tapo SS nariu (Nr. 73041) ir 1933-12-18 jam suteiktas pirmas SS karininko laipsnis - SS sturmfiureris. 1935-04-20 SS obersturmfiurer ir pradejo vadovauti Wiurtembergo politinei policijai. 1936-01-30 tapo SS hauptsturmfiureriu, o lygiai po metų - SS sturmbannfiureriu. Nuo 1937-05-11 iki tụ pačių metų gruodžio - Breslau saugumo policijos ir SD viršininkas. 1938-05-20 užėmè saugumo policijos ir SD inspektoriaus pareigas Vienoje (XVII ir XVIII karinès apygardos), lygiagrečiai buvo SS Einsatzgruppe Wien ir SS Einsatzgruppe II Brünn vadovas. Tų pačių metų 04-20 jam buvo suteiktas SS obersturmbannfiurerio, o po nepilno ménesio, 05-15 - SS štandartenfiurerio laipsnis. Nuo 1939-03-15 tapo SS Einsatzgruppe Dresden (Sudetai) vadu. 1939-05-01 suteiktas SS oberfiurerio laipsnis ir nuo 06-02 paskirtas saugumo policijos ir SD vadu Bohemijos ir Moravijos protektorate. 1940-05 - 11 mènesiais vykdé tokias pat pareigas Osle (Norvegija). Nuo 1940-11-14 iki 1941-06-18 dirbo patarèju Užsienio reikalų ministerijoje. Vienu metu šis jaunas ir agresyvus SS generolas Užsienio reikalų ministerijoje vadovavo „Ypatingam biurui Indijos klausimais“, nors jo žinios Rytų klausimais buvo gan kuklios. 1941-03 buvo komandiruotas ị Belgradą vadovauti žvalgybinei veiklai. 1941-02-06 gavo pirmą generolišką laipsnị - SS brigadefiureris ir policijos gen. mjr. RSHA VI valdybos departamento A (SD žvalgyba užsienyje) vadovas. Už sąžiningą tarnyba buvo apdovanotas SS reichsfiurerio Garbès špaga ir Mirties kaukolès žiedu. 
19420329 - 19420902 - SS brigadefiureris ir policijos gen. mjr. teisès dr. Heincas Jostas (Heinz Maria Karl Jost);

19420910 - 19430904 - SS oberfiureris teisès dr. Humbertas Achameris-Pifraderis (Humbert Achamer-Pifrader) ${ }^{162}$;

19430905 - 19440506 - SS oberfiureris Fridrichas Pancingeris (Friedrich Panzinger);

19440506 - 19441017 - SS oberfiureris ir policijos plk. Vilhelmas Fuchsas (Wilhelm Fuchs).

Baltijos valstybiu teritorijose veikusiai $S S$

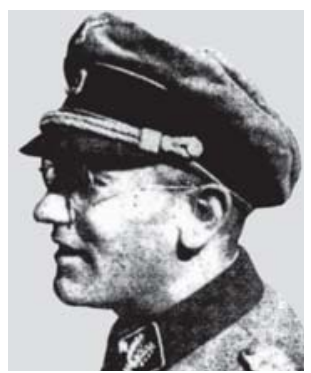

Ostlando vyriausiasis saugumo policijos ir SD vadas, Pabaltijyje veikusios operatyvinès grupès „A“ viršininkas SS brigadefiureris ir policijos generolas majoras dr. F. V. Štalekeris Einsatzgruppe $A$ iš pat pradžių vadovavo ir lygiagrečiai vyresniojo saugumo policijos ir SD vado Ostlando reichskomisariate pareigas vykde $S S$ brigadefiureris ir policijos gen. mjr. teisès dr. F. V. Štalekeris. Nuo 1941 m. birželio 22 d. SS Einsatzgruppe $A$ viršininkas ir nuo lapkričio mén. Ostlando vyresnysis saugumo policijos ir SD vadas. Sutikdamas vadovauti operatyvinei grupei, dr. F. V. Štalekeris siekè atgauti $S S$ grupenfiurerio R. Haidricho malonę, kuris nejautè jam simpatijos. Be to, tai buvo ịsakymas (Befehl ist Befehl). Pažeisdamas griežtą nurodymą, kad, ,asmenys, žinantys valstybines paslaptis, jokiu būdu neturi teisès dalyvauti operacijose, kuriuose jie rizikuoja patekti i priešo nelaisvę“163, generolas nesėdejjo štabe, o aktyviai dalyvavo kovos veiksmuose. $1942 \mathrm{~m}$. kovo 23 d. jis buvo mirtinai sužeistas netoli Krasnogvardejsko kovoje su bolševiku partizanais ir mire karo ligonineje Estijoje ${ }^{164}$. Prahos pilyje ivvykusioje gedulo ceremonijoje, skirtoje žuvusio SS brigadefiurerio ir policijos gen. mjr. dr. F. V. Štalekerio paminèjimui, kalbą pasakè pats RSHA vadovas SS ober-

1621942 metų lapkrityje dr. H. Achamerio-Pifraderio pareigas laikinai vykdè mažai žinomas SS karininkas Röhm.

163 Gestapo ir SD pareigūnai ne bet kada galëjo būti siunčiami ị frontą. Ж. Деларю, История гестапо, Смоленск, 1993, с.189.

164 Anglų autorius E. Crankshaw teigia, kad tai buvo estų partizanai. E. Crankshaw, Gestapo - narzędzie tyranii, Warszawa, 1960, s. 174. 


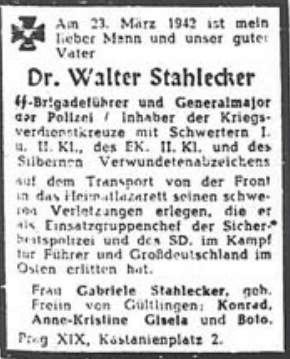

F. V. Stahleckerio mirties nekrologas

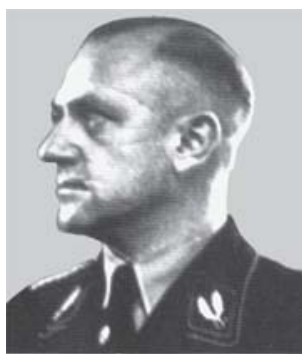

SS brigadefiureris ir policijos generolas majoras dr. H. Jostas

grupenfiureris R. Haidrichas ${ }^{165}$. Ši ceremonija R. Heidrichą gal šiek tiek ir džiugino, nes dauguma RSHA laikè dr. F. V. Štalekerị rimtu R. Haidricho konkurentu užimti RSHA vadovo postą ${ }^{166}$.

Plačiajai istorikų visuomenei tikslios $\mathrm{dr}$. F. V. Stahleckerio žuvimo aplinkybès nèra žinomos. Oficialiame pranešime, paskelbtame vokiečių policijos laikraštyje „Die Deutsche Polizei“, rašoma, kad generolas ,su meile Fiureriui ir Didžiajai Vokietijai žuvo kovoje su bolševizmu“167. Tuo tarpu rusų autorius S. Čertoprudas rašo, kad Sovietų Sajungos Raudonosios Armijos vadovybé, prasidejjus vokiečių - rusų karui, savo tikslams išnaudojo likusius gyvus po stalininių represijų vokiečiu komunistus emigrantus, juolab kad dauguma iš jų igavo puikios žvalgybinès - diversinès veiklos patirtị pilietinio karo Ispanijoje metu. Juos permesdavo per fronto liniją atlikti agitacijos tarp vokiečių kareivių ir karininkų bei likviduoti Vermachto ir Trečiojo Reicho administracijos viduriniosios grandies vadus. Tarp nužudytujų rusų autorius pamini SS oberfiurerį dr. Hansą Nockemaną ir SS Einsatzgruppe A vadą SS brigadefiurerį $\mathrm{dr}$. F. V. Štalekeri ${ }^{168}$.

Žuvusị dr. F. V. Štalekerị SS Einsatzgruppe A viršininko ir Ostlando vyresniojo saugumo policijos ir SD vado poste 1942 m. kovo 29 d. pakeite ganėtinai jaunas SS brigadefiureris ir policijos gen. mjr. teisès dr. Heincas Jostas ${ }^{169}$ (Heinz Maria Karl

165 SS-Mann im Leben und im Sterben, Die Deutsche Polizei, Nr.8, 1504 1942, s. 113.

166 Apie SS brigadefiurerio dr. F.V. Stahleckerio žuvimą oficialus vokiečių saugumo policijos leidinis Befehlsblatt des Chefs der Sicherheitspolizei und des SD informavo tik $1942 \mathrm{~m}$. rugpjūčio 1d. - Befehlsblatt des Chefs der Sicherheitspolizei und des SD, Nr.33, 1.08.1942. - LCVA, f. R-1399, ap. 1, b. 49, 1. 122.

${ }^{167}$ Die Deutsche Polizei, 15. April 1942, Nr. 8.

168 С. Чертопруд, Охота на Фюрера. Тайна неуязвимости Адольфа Гитлера, Москва, 2004, c. 208.

169 Befehlsblatt des Chefs der Sicherheitspolizei und des SD, Nr.16, 18.04.1942. - LCVA, f. R-1399, ap. 1, b. 49, 1. 72. 
Jost $)^{170}$. Būtent jam kai kurie nacizmo istorijos ekspertai priskiria Einsatzgruppe sukūrimo autorystę. Nuo 1939-09-27 iki karo su Sovietų Sajunga pradžios jis buvo RSHA VI valdybos (SD) viršininkas. Valdybos veikloje buvo atskleista pažeidimų panaudojant valiutinius fondus bei vedant apskaitą. Itarimo šešèlis krito ir ant H. Josto ir jam $1941 \mathrm{~m}$. birželio 22 d. laikinai reikèjo palikti aukštas pareigas. Jị šiame poste pakeitė V. Šelenbergas. H. Jostas buvo pažemintas iki eilinio laipsnio ir nusiųstas ị Rytų frontą. Šị ịvykị H. Josto biografijoje iki šiolei gaubia paslaptis. Kito tokio pavyzdžio Trečiojo Reicho slaptujų tarnybų istorijoje nèra. Nė kiek nenukentèjęs karo ugnyje, buvo pasigailètas bei reabilituotas ir $1941 \mathrm{~m}$. rudeni pervestas i Reicho ministerijos užimtoms Rytų sritims darbinị štabą „Kaukazas“. Vèliau, 1942 m. liepos 29 d. rašte A. Hitleriui, reichsministras A. Rosenbergas rekomendavo H. Jostą i Kalmukijos krašto generalinio komisaro postą. 1942 m. pr. H. Jostui buvo grąžintas SS generolo laipsnis ir jis pradejo vadovauti Einsatzgruppe $A$, tačiau ir šias pareigas vykdè neilgai.

Kalbant apie dr. H. Jostą, tenka pažymėti tuos kurie sugebėjo gan pavojingai pasipriešinti nacistų ketinimams ${ }^{171}$. Ir nors tas „perẻjimas į opoziciją“ buvo pavėluotas, tenka ị tai atkreipti dėmesị. Dr. H. Jostas, energinga ir autoritarine asmenybe, kone vienintelis iš SS elito, kuris kategoriškai atsisake vykdyti jam skirtą misiją: pasirinko nepaklusnumą ten, kur lojalumas neatneštu jam garbès. Vadovaudamas Einsatzgruppe $A$, jis susitiko su R. Haidrichu, o po to net su H. Himleriu, kad jiems asmeniškai pareikštų savo priešiškumą žydų eksterminacijos programai. Dèl tokio aktyvumo H. Jostui buvo skirta disciplininè nuobauda ir jis atsidūre Gestapo priežiūroje. 1942 m. rugsejo 2 d. jis buvo atleistas iš Einsatzgruppe $A$ vado pareigu

170 Gimė 1904-07-09 Holzhausene. Išsilavinimą teisès ir ekonominių mokslų srityje įsigijo Hesseno ir Miuncheno universitetuose ir netrukus tapo teisès mokslų daktaru. 1928-01-02 NSDAP narys, bilieto Nr. 75946, o nuo 1929 - SA narys. 1931 advokatavo Lorsche. 1933-03 pradejo dirbti komisariniu policijos direktoriumi Wormse, po to nuo spalio Giessene. 1934-07-25 SS narys, Nr. 36243, 07-27 SS sturmbannfiurerio laipsnyje perëjo tarnauti ị SD. 1935-04-20 SS obersturmbannfiurer. 1936-04-20 SS štandartenfiureris ir Vyriausiosios SD ịstaigos kontržvalgybos skyriaus vadovas. Organizavo žvalgybinį darbą pilietinio karo metu Ispanijoje. 1937-04-20 SS oberfiurer. 1938-09 vadovavo SS Einsatzgruppe Dresden. Nuo 1939-03-15 SS Einsatzgruppe Wien (Sudetai) vadas. 1939-04-20 suteiktas SS brigadefiurerio, o 1941-01-01 policijos gen. mjr. laipsnis. Už sąžiningą tarnybą buvo apdovanotas auksiniu NSDAP ženkleliu, SS reichsfiurerio Garbès špaga ir Mirties kaukolès žiedu.

${ }^{171}$ H. Josto pažiūroms atvirai pritare EG „D“ aukštas pareigūnas EK 12 vadas SS obersturmbannfiureris Gustavas Nosske. Kaip teigè teismo proceso metu, panašiai elgèsi EG „D“ vadas SS grupenfiureris Otto Olendorfas ir šiuo klausimu buvo netgi pas H. Himlerį, su kuriuo nebuvo abipusès simpatijos. 
ir paskirtas Reicho ministerijos užimtoms Rytų sritims igaliotinių prie armijų grupès „A“ su būstine Nikolajeve. 1944 m. pr. grįžo ị Berlyną ir išèjo i pensiją. Po ilgo tyrimo, $1944 \mathrm{~m}$. balandžio mẻn., SS gen. H. Jostas buvo degraduotas iki seržanto laipsnio ir pervestas tarnauti i Waffen - SS dalinius. Tačiau, kaip rodo dokumentai, tų pačių metų rudenį buvo reabilituotas. SS Vyriausiosios personalo valdybos leidžiamame SS karininkų sąraše jo pavardẻ užèmé garbingą 227-ą vietą ${ }^{172}$. Vis dèlto $1945 \mathrm{~m}$. sausi jis buvo išbrauktas iš SS narių sąrašų. Po karo, 1949 m., amerikiečių karinio tribunolo nr. 9 nuteistas mirties bausme, tačiau, atsižvelgiant į jo priešiškumą nacistinei žydų eksterminacijos programai bei tarpininkaujant VFR vyriausybei, $1951 \mathrm{~m}$. sausio mẻn. bausmė buvo sumažinta iki 10 metų, o $1951 \mathrm{~m}$. gruodžio mèn. dr. H. Jostas paleistas ị laisvę. Iki mirties, t. y. 1964 m. lapkričio 12 d. ${ }^{173}$, buvo daugelio Vokietijos koncernu patarejas teisininkas ekonomikos klausimais bei savarankiškas ekonomistas Diuseldorfe.

Pašalintą iš pareigų SS brigadefiurerį H. Jostą pakeite į Rygą atvykęs jo kolega SS štandartenfiureris teisès dr. Humbertas Achameris-Pifraderis (Humbert Achamer-Pifrader $)^{174}$. Nuo 1942 m. rugpjūčio 26 d. iki 1943 m. rugsẻjo 4 d. jis buvo Ostlando vyresnysis saugumo policijos ir SD vadas bei saugumo policijos ir SD ịgaliotinis prie armijų grupès „Šiaureં“, o nuo rugsẻjo 10 d. - lygiagrečiai operatyvinès grupés „A“ viršininkas. Be šių pareigų nuo 1942 m. spalio 23 d. iki 1943 m. liepos 28 d. jis buvo kovos su sovietiniais partizanais kovinių junginių štabo viršininkas (Führungsstab für Bandenbekämpfung). Už sėkmingą pareigų

172 Dienstaltersliste der Schutzstaffel der NSDAP (SS-Oberstgruppenfuhrer - SS-Standartenfuhrer), Stand vom 9. November 1944, Berlin, 1944, s. 16.

173 Leidinyje Энииклопедия Третьего рейха, Москва, 1996, с. 247 teigiama, kad H. Jostas buvo vienas iš paskutinių karinių nusikaltẻlių, pakartų 1951 metais Landsbergo kalejjime.

174 Gimè 1900-11-21 Sudetuose. Dalyvavo I p. k., o po karo baigè aukštąsias teisès studijas. Mokejjo prancūzų kalbą. 1940 apsigyne disertaciją ir tapo mokslų daktaru. Kai po I p. k. Sudetai atsidūrè Čekoslovakijos sudėtyje, išvažiavo ị Austriją ir pradejjo tarnybą Zalcburgo geležinkelių policijoje. 1931-11-10 įstojo į NSDAP austrų skyrių (bilieto Nr. 614104). Saugodamasis arešto, pabėgo ị Vokietiją ir priimtas ị Miuncheno policiją. 1935-09-03 SS narys (bilieto Nr. 275750), 1936-04-15 pervestas ị gestapo centrinį aparatą Berlyne. 1936-01-30 SS untersturmfiureris. 1938 metais SS hauptsturmfiurerio laipsnyje pradèjo vadovauti gestapo II C 1 skyriui (austru pabègèliai). 1938-03-12 SS obersturmbannfiuris. 1939-03 komandiruotas ị Vieną organizuoti gestapo tarnybos. 1940-04-14 saugumo policijos ir SD inspektoriaus pavaduotojas Wiesbadene ir lygiagrečiai nuo 06-01 vadovavo gestapo poskyriui Darmštadte. Abi šias pareigas ejo iki 1942-07-01. Tą dieną jis tapo saugumo policijos ir SD inspektoriumi Wiesbadene. 1941-11-09 SS štandartenfiureris. Nuo 1942-04 dirbo RSHA. Nuo 1943-09-04 iki 1944-01-09 saugumo policijos ir SD inspektorius Štetine. Nuo 1944-02-26 pervestas ị centrinį aparatą Berlyne ir tapo RSHA IV valdybos vadovaujančios grupès „B“ bei referato IV B 1 vadovu. Žuvo 1945-04-25 Linze oro antskrydžio metu. 
vykdymą Ostlande 1943 m. sausio 1 d. pakeltas iki SS oberfiurerio laipsnio, o tų pačių metų rugpjūčio 31 d. apdovanotas II klasės Geležiniu kryžiumi.

1943 m. rudenị E. Kaltenbruneris ị Ostlandą

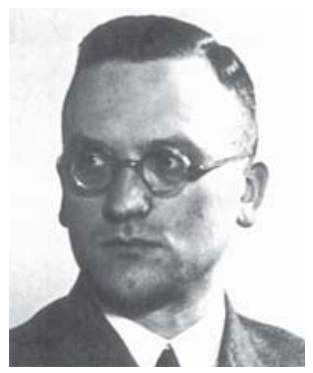

SS oberfiureris F. Pancingeris atsiuntė aukštą Vyriausiosios Reicho saugumo valdybos pareigūną SS oberfiurerį Fridrichą Pancingerị (Friedrich Panzinger) $^{175}$. Jis dar 1941 m. birželio mèn. Pabaltijyje veikè su „A“ operatyvine grupe. 1943 m. rugsejjo $5 \mathrm{~d}$. paskirtas vokiečių saugumo policijos ir SD vyresniuoju vadu Ostlande. Kartu jis buvo atsakingas už SD operatyvinę grupę „A“.

Naujasis Ostlando saugumo policijos ir SD vadovas F. Pancingeris SS reichsfiureriui $\mathrm{H}$. Himleriui i̊sipareigojo sunaikinti bet kokias bolševizmo apraiškas jo teritorijoje, visiškai likviduoti sovietinị ir kitokị partizanini judejjimą Pabaltijyje bei pagerinti žvalgybinę veiklą. Savo pokario parodymuose 1949 m. gruodžio 16 d. sovietiniams tardymo organams jis teigė: „Vyriausiosios Reicho saugumo valdybos įsakymu aš buvau paskirtas į Pabaltiji ̨ saugumo policijos vyresniuoju vadu. Man buvo pavaldūs visi gestapo ir SD organai Latvijos, Lietuvos ir Estijos teritorijoje. $<\ldots>$ Saugumo policijos vado pareigoms Pabaltijyje buvo reikalingas ne budelis, kokiu buvo Pifraderis, o kvalifikuotas žvalgas, turintis puikių žvalgybinio darbo $<\ldots>$ žinių. $<\ldots>$ Miuleris specialiai man nurodè atkreipti ypatingą dėmesị i kovą su komunistiniu pogrindžiu Pabaltijyje ir partizanų slopinimą... Taikant griežtas priemones man pavyko iki tam tikro lygio nuslopinti partizanini judejimą kai kuriuose Pabaltijo rajonuose ir likviduoti daug komunistinių pogrindinių organizacijų... Po pusantro mėnesio, kai aš pradejjau eiti savo par-

175 Gimė 1903-02-01 Miunchene. Po I p. k. universitete studijavo teisę. Nuo 1933-07-10 SA narys. 1934-12-01 pradejo tarnybą policijoje. 1937-10-01 perkeltas i gestapo būstinę Berlyne. 1937-05-01 NSDAP narys (bilieto Nr. 5017341), 1939-04-20 SS narys (bilieto Nr. 322118). Nuo 1939-04-20 SD pareigūnas. Tapęs artimu H. Miulerio draugu, 1940-08 perèjo ị RSHA ir vadovavo IVA grupei (kova su nacionalsocializmo priešais, sabotažas, apsaugos tarnyba). Buvo „Sonderkommission Rote Kapelle“, tiriančios „Raudonosios kapelos“ veiklą (sovietų žvalgybos tinklas Vakarų Europoje - P. S.), vadovas. Apdovanotas I klasės Kovinių nuopelnų kryžiumi su kalavijais. Nuo 1943-01-25 paaukštintas iki Regierungsdirektor. Nuo 1944-08-15 tapo RSHA V valdybos (kriminaliné policija) viršininku. 1946-10-03 dieną pateko ị rusų rankas ir teismo, įvykusio 1952-03-22 Maskvoje, nuteistas 25 metus kalèti. Būdamas nelaisvejje, buvo užverbuotas ir tapo sovietinio saugumo agentu. 1955-09 amnestuotas ir perduotas Vakarų Vokietijai. Atsidūręs Tèvynèje, atvyko ị R. Gehleno tarnybą ir prisipažino esąs užverbuotas sovietų žvalgybos. 1959, netrukus prieš numatomą suėmimą, 08-08 dieną Miunchene nusinuodijo ciano kaliu. 
eigas, inspekcijos tikslais ị Rygą atvyko Himleris $<\ldots$... ${ }^{\text {"176 }}$.

Šias atsakingas pareigas Ostlande F. Pancingeris vykde iki 1944 m. gegužès 6 d. Nuo 1943 m. balandžio 20 d. - SS štandartenfiureris. 1944 m. gegužès 21 d., jau kaip SS oberfiureris, grižo ị Berlyną ir vėl tapo Vyriausiosios reicho saugumo valdybos IVA grupès vadovu.

Paskutiniuoju Ostlando saugumo policijos ir SD vyresniuoju vadu nuo 1944 m. gegužès $6 \mathrm{~d}$. iki tų pačių metų spalio $17 \mathrm{~d}$. buvo SS oberfiureris ir policijos plk. Vilhelmas Fuchsas (Wilhelm Fuchs), apie kurị plačiau bus kalbama vẻliau.

Faktiškai jau nuo 1941 m. liepos 2 d. iki 1944 m. gruodžio 31 d. vokiečių saugumo policijos ir SD vado Lietuvos generalinejje srityje (dokumentuose šios pareigos oficialiai skambejjo taip: Der Beauftragte des Chefs der Sicherheitspolizei und des SD fur Litauen, Dienststelle Kauen) pareigas vykdè šie aukšto rango vokiečių SS karininkai:

19410702 - 19430731 - SS štandartenfiureris Karlas Jegeris (Karl Jäger);

19430801 - 19440511 - SS oberfiureris ir policijos plk. Vilhelmas Fuchsas (Wilhelm Fuchs);

19440511 - 19441231 - SS oberšturmbannfiureris Hansas Joachimas Biomė (Hans-Joachim Böhme).

Tai buvo energingi, užgrūdinti ir išsimokslinę savo srityje specialistai. Vieni su savo SS ir policijos vadais sugyveno harmoningai, kiti konfliktuodavo. Pirmuoju vokiečiu saugumo policijos ir SD vadu Lietuvos generalinejje srityje tapo operatyvinès grupès „A“ operatyvinio būrio 3/A (Einsatzkommando 3/A) vadas, gan senyvo amžiaus SS štandartenfiureris (plk.) Karlas Jegeris (Karl Jäger) ${ }^{177}$. Nuo pat karo pradžios su Sovietų Sajunga jis buvo

176 Л. Барков, В дебрях абвера, Таллин, 1971, с. 91-92.

177 Gime 1888-09-20 Schaffhausene (Šveicarija). Mokèsi prekybos amatų mokykloje bei Valdkirche konservatorijoje. I p. k. dalyvavo kaip eilinis kareivis: už kovinius nuopelnus buvo apdovanotas II ir I klasės Geležiniais kryžiais. Po karo dirbo techniku, vèliau užsiėmè komercija. Netrukus tapo muzikinių instrumentų fabriko bendrasavininku. Taip vadinamojo „Juodojo reichsvero“ narys. 1923-03 įstojo ị NSDAP (bilieto Nr. 359269). 1932-03-15 įstojo ị SS (bilieto Nr. 62823). 1934-0420 gavo pirmą SS karininko laipsni - SS untersturmfiurerio. 1935-09-15 pakeltas iki SS obersturmfiurerio. Nuo 1935 tarnavo Liudvigsburge ir Ravensburge SS padalinio vadovu. 1936-09-13 tapo SS hauptsturmfiureriu, 1937-09-12 SS sturmbannfiureris. Nuo 1938 SD viršininkas Miunstere ir nuo tų pačių metų 09-11 SS obersturmbannfiureris. Dalyvavo užimant Beniliukso šalis. 1940-09-01 buvo paskutinį kartą paaukštintas iki SS štandartenfiurerio. Policijos plk. laipsnis jam niekados nebuvo suteiktas, kadangi dauguma SD karininkų turëjo tik SS laipsnius. 1942 m. jo sūnus žuvo Rytų fronte. 1943 m. pabaigoje grižo ị Vokietiją. Po laikino buvimo rezerve, 1944-05-24 tapo komisariniu policijos prezidentu Reichenberge (Sudetai). Po karo pasikeite pavardę ir tapo fermeriu. Tik praejjus keturiolikai metų po karo buvo atpažintas ir 1959-06 vokiečių policijos buvo suimtas ir apklausiamas. 1959-06-22 nusižude, pasikardamas kalējimo kameroje Hoenasperge. 


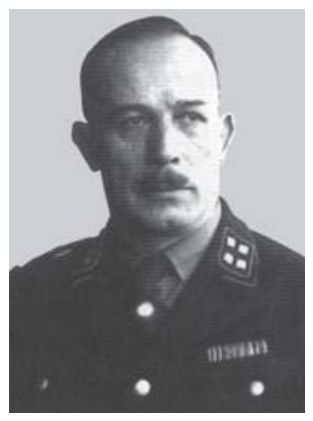

Saugumo policijos ir

SD vadas Lietuvos generalinëje srityje SS štandartenfiureris K. Jegeris

operatyvinès grupès „A“ 3-iojo operatyvinio būrio viršininkas. Ir tik nuo 1941 m. gruodžio 3 d. užėmé saugumo policijos ir SD vado postą Lietuvos generalinėje srityje, lygiagrečiai iki $1942 \mathrm{~m}$. lapkričio mèn. vykdydamas operatyvinès grupès „A“ 3-iojo operatyvinio būrio (Einsatzkommando 3/A) vado pareigas ${ }^{178}$. Kaip sovietų tardymo organams savo pokariniuose parodymuose teige vyriausiasis karo komendantas Lietuvoje gen. mjr. Emilis Justas ${ }^{179}$, esą dèl savo minkštumo, ypač pasireiškusio akcijose prieš žydus ir kovose su sovietiniais partizanais, K. Jegeris netiko į tas pareigas ir $1943 \mathrm{~m}$. rugsejjo $15 \mathrm{~d}$. buvo atleistas iš užimamo posto ${ }^{180}$.

Likus šešioms dienoms iki mirties, 1959 m. birželio 15 d., K. Jegeris spejjo duoti tardymo organams parodymus apie pasitarimą RSHA, ìvykusi $1941 \mathrm{~m}$. birželio 17 d., kurio metu buvo sukonkretintos SS operatyvinių grupių bei saugumo policijos ir SD vadų funkcijos būsimo karo Rytuose metu ${ }^{181}$. Vokiečių istorikas Hansas-Heinrichas Wilhelmas savo knygoje „Rassenpolitik und Kriegsführung. Sicherheitspolizei und Wehrmacht in Polen und in der Sowjetunion 1939-1942“ ivvardijo Karlą Jegerị „kaip veikiausiai produktyviausią masinį žudiką naujausioje istorijoje“. Tuo tarpu pats kaltinamasis priešmirtiniame laiške, adresuotame ji apklausiantiems tardytojams, rašé: „Atsisveikinu su šiuo pasauliu $\langle\ldots\rangle$. Dar kartą pabrěžiu $\langle\ldots\rangle$, kad niekad nepripažinau žydų šaudymo ir kad karo metu buvau paskirtas i pareigas prieš savo įsitikinimus. Niekados neliepiau šaudyti žydų, niekad neįsakiau vykdyti egzekucijų, tepadeda man Dievas. Neįvykdžiau jokio nusikaltimo <...>“182.

1997 m. Simono Wiesenthalio centras 60-yje laikraščiu 27 pasaulio šalyse paskelbė po Antrojo pasaulinio karo Šveicarijos bankuose paslèptų

\footnotetext{
178 Nuo 1942-11 iki 1943-05 operatyvinès grupès „A“ 3-iojo operatyvinio būrio (Einsatzkommando 3/A) (štabas Pskove) vadu buvo SS obersturmbannfiureris Karlas Traut.

179 Lietuviai okupantų vokiečių akimis. Generolo Emilio Justo parodymai. Laisvès kovų archyvas, t. 9, Kaunas, 1993, p. 148.

180 K. Rukšènas, pasiremdamas vokiškais šaltiniais, savo disertacijoje (p. 211) rašo, kad K. Jegeriui pakriko nervai ir jis buvo išsiųstas gydytis.

181 T. Szarota, U progu zagłady. Zajścia antyżydowskie i pogromy w okupowanej Europie. Warszawa, 2000, s. 213.

182 Ten pat, s. 267.
} 
vokiečių sąskaitų sąrašą. Tarp sąskaitų savininkų (indėlininkų) buvo paminètas ir Karlas Jegeris ${ }^{183}$.

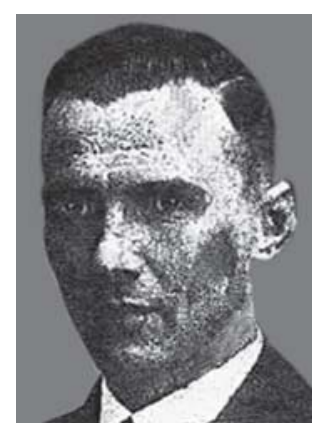

Saugumo policijos ir SD vadas Lieuvos generalinejje srityje SS oberfiureris V. Fuchsas

K. Jegeris buvo atleistas iš posto ir išsiųstas i Vokietiją. Nuo 1943 m. rugsèjo 15 d. kitu vokiečiu saugumo policijos ir SD vadu (Befehlshaber der Sicherheitspolizei und des Sicherheitsdienstes), o lygiagrečiai operatyvinès grupès „A“ operatyvinio būrio 3/A (Einsatzkommando 3/A) vadu Lietuvos generalinejje srityje buvo paskirtas dešimčia metų už pirmtaką jaunesnis ekonomikos mokslų daktaras SS oberfiureris Vilhelmas Fuchsas (Wilhelm Fuchs $)^{184}$. Apibūdindamas naują vadą, Kauno gestapo viršininkas SS hauptšturmfiureris dr. Heinrichas Šmitcas pareiške generolui E. Justui, kad „šis pasikeitimas būsiąs nelaimé Lietuvai, nes Fuchsas yra kaip reta brutalus ir negailestingas žmogus“"185. Naujas SD viršininkas Lietuvoje savo ypatingu uždaviniu laikè sunaikinti slaptają rezistencinę lietuvių spaudą ir išrankioti dar pasislėpusius Lietuvoje „žemesnès rasès Lietuvos gyventojus“. Jo ịsakymu nuo 1943 m. gruodžio mèn. visas karui svarbias Lietuvos įmones pradejo tikrinti gestapo pareigūnai. Jie žiūrèjo, kas nusižengia darbo drausmei, pabėga iš darbo, pareikšdavo griežtus įspejjimus nusižengusiems darbo drausmei, o kai kuriais atvejais rekomenduodavo prieš pažeidejus imtis būtinų veiksmų ${ }^{186}$. Netrukus

183 „Šveicarijos bankų sąraše - ir Lietuvoje tarnavęs nacis“, Lietuvos rytas, 1997-07-25, Nr. 172 (2001).

184 Gimė 1898-09-01 Manheime. I p. k. dalyvis, apdovanotas II ir I klasès Geležiniais kryžiais. Studijavo Leipcigo universitete ekonomiką. Nuo 1932-04-01 buvo NSDAP nariu (bilieto Nr. 1038061), vèliau - 12-01 - tapo SS nariu (bilieto Nr. 62760). Už dalyvavimą nacionalsocialistiniame judejime iki 1923, buvo apdovanotas retu Kraujo ordinu (Blutorder) Nr. 765. Nuo 1936 SS karininkas SS Vyriausiojoje rasių valdyboje. 1937 SS štandartenfiureris SD Vyriausioje valdyboje. 1940 SD referentas prie saugumo policijos ir SD vado Generalineje Gubernatorystejje. Nuo 1941 pavasario saugumo policijos ir SD operatyvinès grupès viršininkas Jugoslavijoje. 1942-05-01 SS oberfiureris ir policijos plk. Išvykęs iš Ostlando, V. Fuchsas tapo vyriausiuoju SS ir policijos vadu Serbijoje. Už nuopelnus Reichui ir SS H. Himlerio įsakymu buvo apdovanotas SS Garbès špaga ir Mirties kaukolès žiedu, I klasės Karo kryžiumi už nuopelnus su Kardais. 1946-12-22 Belgrado teismo nuteistas mirti pakariant ir 1947-01-24 pakartas.

185 Lietuviai okupantų vokiečių akimis. Generolo Emilio Justo parodymai. Laisvès kovų archyvas, t. 9, Kaunas, 1993, p. 148.

${ }^{186}$ LCVA, f. R-1399, ap. 1, b. 61, 1. 181. 


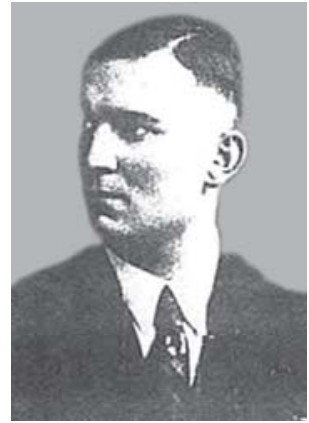

Saugumo policijos ir

SD vadas Lietuvos generalinèje srityje SS obersturmbannfiureris H. J. Biomé

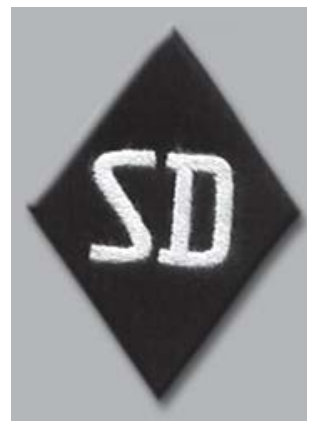

Saugumo tarnybos pareigūnų ant kairès rankovès žemiau alkūnès nešiotas rombas su raidėmis $\mathrm{SD}$
V. Fuchsas buvo paaukštintas ir nuo $1944 \mathrm{~m}$. gegužès 6 d. užèmė analogiškas pareigas Ostlande bei lygiagrečiai tapo SS operatyvinès grupès „A“ (SS Einsatzgruppe A) vadu.

Paskutiniuoju Lietuvos generalinès srities saugumo policijos ir SD vadu nuo 1944 m. gegužès 11 d. iki tų pačių metų paskutinès dienos buvo gan jaunas (35 metų) SS oberšturmbanfiureris Hansas Joachimas Biomė (Hans-Joachim Böhme) ${ }^{187}$. Dar $1941 \mathrm{~m}$. birželio mèn. Lietuvos pasienyje jis vadovavo improvizuotai Einsatzkommando „Tilsit“. Ir tiktai nuo 1944 m. gegužès $11 \mathrm{~d}$. jis tapo Lietuvos generalinès srities saugumo policijos ir SD bei lygiagrečiai operatyvinès grupès „A“ operatyvinio būrio 3/A (Einsatzkommando 3/A) vadu.

Saugumo policijos ir SD vadovo pareigas užimtose Rytų srityse galèjo eiti tik tie SD karininkai, kurie pasižymejo politiniu aktyvumu partijoje ir buvo profesionalūs policinio darbo specialistai, turintys reikiamą kvalifikaciją įsakinèti trims tarnyboms - gestapui, kriminalinei policijai ir SD. Visi jie be išimties buvo patyrę slaptosios valstybinès policijos funkcionieriai, užimantys vadovaujančias pareigas. Vyriausiajam iš jų buvo 53 metai, jauniausiajam - 35 (metų vidurkis - 44 metai). Iš to galima daryti išvadą, kad visi Lietuvos generalinès srities saugumo policijos ir SD vadai padare tarnybos policijoje karjerą jau tuo laiku, kai vokiečių tauta patikejjo valstybès vairą A. Hitlerio partijai ir susiejo savo likimą su šia partija.

187 Gimè 1909-01-10 Magdeburge. Turëjo universitetinį išsilavinimą. 1933-05-01 tapo NSDAP (bilieto Nr. 2316680) ir 11-01 SS nariu (bilieto Nr. 151121). 1941 paskirtas gestapo viršininku Tilžėje. Nuo 1941-02-06 valstybės tarèjas (Regierungsrat). 1941-04-20 tapo SS šturmbannfiureriu. 1943 paskirtas saugumo policijos ir SD viršininku Žitomire. Nuo 1945 pervestas i RSHA ir 01-30 jam suteiktas SS štandartenfiurerio laipsnis. Karo pabaigoje tarnavo 4-oje SS policijos divizijoje „Polizei“. Vakarų Vokietijos Ulmo miesto teismas 1958-04-28 - 08-29 surenge jam teismo procesą. Buvo nuteistas 15 metų sunkiujų darbų kalejimo ir 10 metų pilietinių teisių sustabdymo. Tačiau atlikti bausmès jam nebuvo lemta - 1960-05-31 mirè. 
Lentelẻ nr. 4 „Lietuvos generalinès srities SS ir policijos bei saugumo policijos ir SD vadai" ${ }^{188}$

\begin{tabular}{|c|c|c|c|}
\hline $\begin{array}{c}\text { SS ir policijos } \\
\text { vadas }\end{array}$ & Laikotarpis & $\begin{array}{c}\text { Saugumo policijos ir SD } \\
\text { vadas }\end{array}$ & Laikotarpis \\
\hline $\begin{array}{l}\text { SS brigadefiureris } \\
\text { L. D. Vysokis }\end{array}$ & $\begin{array}{l}1941-08-11- \\
1943-07-02\end{array}$ & $\begin{array}{l}\text { SS štandartenfiureris } \\
\text { K. Jegeris }\end{array}$ & $\begin{array}{l}1941-07-02- \\
1943-07-31\end{array}$ \\
\hline $\begin{array}{l}\text { SS brigadefiureris } \\
\text { H. Harmas }\end{array}$ & $\begin{array}{l}1943-07-02- \\
1944-04-08 \\
\end{array}$ & $\begin{array}{l}\text { SS oberfiureris } \\
\text { V. Fuchsas }\end{array}$ & $\begin{array}{l}1943-08-01- \\
1944-05-11\end{array}$ \\
\hline $\begin{array}{l}\text { SS brigadefiureris } \\
\text { K. Hintce }\end{array}$ & $\begin{array}{l}1944-04-04- \\
1944-09-15\end{array}$ & $\begin{array}{l}\text { SS oberšturmbannfiureris } \\
\text { H. J. Biomé }\end{array}$ & $\begin{array}{l}1944-05-11- \\
1944-12-31\end{array}$ \\
\hline
\end{tabular}

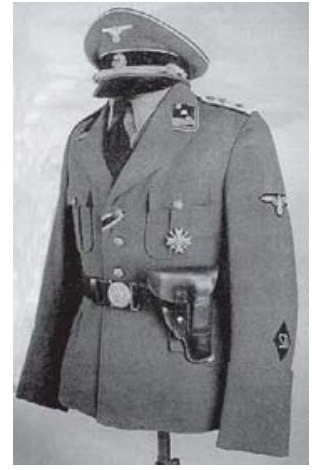

SD karininko tarnybinis munduras kasdienai

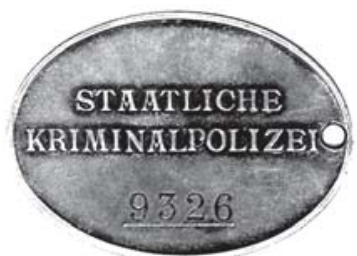

Kriminalinès policijos pareigūno tarnybinis ženklelis
Sprendžiant iš pateiktos vadovaujančių SS vadovų kadrų kaitos analizès, kiekvienas naujai paskirtas SS ir vokiečiu policijos vadas Lietuvos generalinėje srityje stengèsi greitai pakeisti ir vokiečiu saugumo policijos ir SD vadą.

Lietuvos generalinèje srityje karo metais buvo dislokuota nemažai svarbių Trečiojo Reicho įstaigų. Jų saugumu privalejjo rūpintis saugumo policija ir SD. $1941 \mathrm{~m}$. liepos $25 \mathrm{~d}$. i Kauną laikinai atvyko Ostlando reicho komisaras NSDAP gauleiteris Hinrichas Lozè (Lohse). Šiame mieste jis ịkūrè savo laikiną rezidenciją, kol Latvija dar nebuvo galutinai Vermachto užimta. Be to, Lietuvos generalinèje srityje veikè daugiau nei 60 vokiškų firmų bei bendrijų ${ }^{189} .1941$ - 1942 m. kažkur prie Rygos ir Minsko, t. y. netoli Lietuvos generalinès srities, o gal ir jos teritorijoje, slaptai lankèsi A. Hitleris. Vilniuje buvo dislokuota Vokietijos oro pajègu, kovojančių Rytuose, intendantūra (gen. Plageman). Perkèlus iš Vokietijos i Lietuvą Vermachto mokomąsias ir atsargos divizijas, 1942 m. Kaune buvo ikurta Ver-

188 P. Stankeras, „Aukščiausioji vokiečių SS ir policijos vadovybė Lietuvos generalinėje srityje 1941 - 1944 metais“, Genocidas ir rezistencija, 2001, Nr.2 (10), p. 17 - 30.

189 М. И. Семиряга, Тюремная империя нацизма и ее крах, Москва, 1991, с. 201. 
machto puskarininkių mokykla. $1943 \mathrm{~m}$. į Lietuvos generalinę sritị buvo perkelti Vermachto LXI rezervinio korpuso, turinčio savo sudètyje 141-ą bei 151-ą mokomąsias divizijas, daliniai.

$1941 \mathrm{~m}$. liepos 17 d. A. Hitleris ịvesdamas civilinị administravimą pasirašè dekretą „Dèl užimtų rytinių teritorijų policinio saugumo“. Šiuo dekretu $S$ S reichsfiureris H. Himleris gavo teisę leisti generalinių sričių Reicho komisarams direktyvas saugumo klausimais. Nuo to laiko SS ir policijos karininkai buvo pavaldūs ne Reicho komisarams, o H. Himleriui. Lapkričio mènesi H. Himleris ir A. Rosenbergas (nors jų požiūris ị Reicho rytų politiką skyrèsi) vis dèlto kartu apibréžè policijos vadovų igaliojimus; juose buvo ir vokiečių dalinių priežiūra, bendrasis saugumas, vietinè policija (Schutzmannschaften), ir teisè leisti atitinkamas instrukcijas. Tarp svarbių teisés aktų, išleistų per dešimt savaičių nuo karo pradžios, yra dẻmesio verti dekretai „Dèl aukščiausios bausmès už nepaklusnumą okupacinei valdžiai“ (rugpjūčio 23 d.), „Dèl vokiečių baudžiamojo kodekso ir vokiečių teismų veiksmingumo išplètimo“ (rugsẻjo 4 d.), „Dèl privalomo gyventojų nuo 18 iki 45 metų įsidarbinimo“ (rugsejo 5 d.), „Dèl karo lauko teismų“ (rugsèjo 23 d.). Tų pačių metų spalio $11 \mathrm{~d}$. A. Hitleris oficialiai išvede Ostlando reichskomisariatą iš Vermachto jurisdikcijos. Egzistuoja versija, kad SS reichsfiureris H. Himleris tikejosi, kad būtent jo tarnybų aparatas perims ị savo rankas visą administravimo sistemą Rytuose.

Vokiečių policinè valdžia Ostlande turèjo kelis lygius. Pirmas lygis ir aukščiausioji policinè institucija buvo aukštesnysis SS ir policijos vadas (Höherer SS- und Polizeiführer, toliau HSSPF) SS obergrupenfiureris ir policijos gen. Fridrichas Jekelnas (Friedrich Jeckeln) ${ }^{190}$. Jo būstinè buvo dislokuota Rygoje - Ostlando sostineje. Pagal A. Hitlerio $1941 \mathrm{~m}$. liepos 17 d. administracinio valdymo dekretą Ostlando HSSPF buvo pavaldus Ostlando

\footnotetext{
190 Gimè 1895-02-02 Hamberge (Švarcvalde) fabrikanto šeimoje. I pasauliniame kare dalyvavo kaip eilinis kareivis, paskui tapo savanorių korpuso nariu. Nuo 1929 NSDAP narys (bilieto Nr. 163348), nuo 1930 SS narys (bilieto Nr. 4367). Pagal išsilavinimą architektas. Nuo 1930-0315 SS štandartenfiureris. 1932-1943 Reichstago deputatas. Nuo 1933 trijų provincijų SS vadovas; 1936-04-1940-07 SS apygardos „Centras“ vadas. Nuo 1936-09-13 SS obergrupenfiureris, 194007-1941-05 grupès „Vakarai“ aukštesnysis SS ir policijos vadas (Diuseldorfas). Nuo 1941-06-29 aukštesnysis SS ir policijos vadas „Rusija-Pietus“ ir Ukrainoje, o nuo 1941-11 „Rusija-Šiaure““ ir Ostlande. 1944 gen. Waffen-SS. 1944-08-27 apdovanotas Geležinio kryžiaus riterio kryžiumi. 1945-03 -05 Waffen-SS V savanorių kalnų korpuso vadas. 1945-03-05 kaip 802-asis Vermachto karys apdovanotas Ąžuolo lapais prie Geležinio kryžiaus riterio kryžiaus. 1946-02-03 Pabaltijo karinès apygardos karo tribunolo nuosprendžiu pakartas Rygoje.
} 


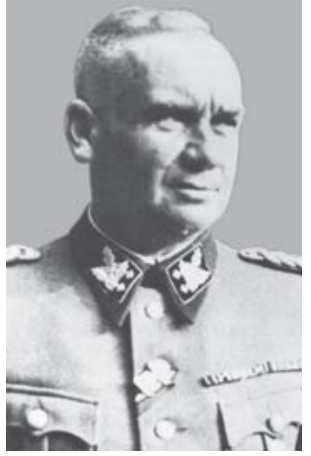

Ostlando vyriausiasis SS ir policijos vadas SS obergruppenfiureris ir policijos generolas F. Jekelnas

reicho komisarui Hinrichui Lozei (Hinrich Lohse). SS ir policijos vadų veiklą Rytuose, labiau negu pačiame Reiche, nepastebimai kontroliavo tiesiogiai jiems pavaldūs saugumo policijos ir SD vadai. SS ir policijos vadai galejo leisti tik tokius įsakymus, kurie neprieštaravo saugumo policijos ir SD nurodymams ${ }^{191}$.

Tuo pačiu metu vyravo nematoma îtampa ir pačioje SS organizacijoje - tarp HSSPF ir SS ir policijos vado (SS- und Polizeiführer, toliau SSPF) - iš vienos pusès ir saugumo policijos, t. y. RSHA bei jos vadovo Reinhardo Haidricho (Reinhard Haidrich), - iš kitos pusès. Pagal oficialiai patvirtintą struktūrą tarp RSHA ir jai pavaldžios saugumo policijos Ostlande egzistavo tiesioginis tarnybinis ryšis. Apie tuo keliu einančius įsakymus HSSPF ir SSPF buvo informuojami, atskirais atvejais galejo juos netgi atkeisti arba kreiptis tuo klausimu tiesiogiai i RFSS. Be to, jiems priklausé galutinio sprendimo teise akcijose, turinčiose ypatingą politinę reikšmę.

Antras policinis lygis Ostlande - F. Jekelno štabo nariai, kurių kiekvienas atstovavo vienai ar kitai Vyriausiajai SS valdybai (saugumo, tvarkos policijos vadai, Waffen $S S$ vadas, administracinès ūkinès SS valdybos atstovas ir kt.). Taip pat antram lygiui priklausé kiekvienos generalinès srities SS ir policijos vadai (SSPF), kurie formaliai buvo pavaldūs generaliniam komisarui. Trečiam lygiui priklausè žemesnio rango SS ir policijos vadai, kurie savo ruožtu buvo pavaldūs apygardų komisarams. Bet šis pavaldumas buvo savotiškas: jo tikslas savotiškai parodyti administravimo vientisumą. Be to, minètasis A. Hitlerio dekretas nustatė, kad užimtų sričių policinę apsaugą garantuoja SS reichsfiureris H. Himleris, kuris savo ruožtu buvo igaliotas tuo klausimu komisarams skirti būtinus pavedimus. Taigi situacija susiklostė tokia, kad SS ir policijos vadai buvo ịtraukti ị komisarų štabus, bet formaliai ${ }^{192}$. Specialūs policiniai ịgaliojimai, gauti iš H. Himlerio, vadams sudaré ịspūdị, kad komisarai turi būti pavaldūs jiems, o ne atvirkščiai. Be to, HSSPF ir SSPF pavaldumas SS reichsfiureriui buvo daug svarbesnis negu formalus pavaldumas reichskomisarui

191 Нюрнбергский процесс, Москва, 1960, т. VI, с. 164.

192 J. Turonek, Bialorus pod okupacją niemiecką, Warszawa, 1993, s. 87-88. 
ar generaliniam komisarui, panašiai kaip vokiečių policijos vado formalus pavaldumas Reicho vidaus reikalų ministrui buvo žemesnio lygio palyginus su SS reichsfiurerio pavaldumui A. Hitleriui.

Taip pat vokiečių policijos trečiam lygiui priklausė generalinès srities saugumo policijos ir SD bei tvarkos policijos vadai. Formaliai Lietuvos generaliniam komisarui Adrianui Teodorui fon Rentelnui buvo priskirta saugumo policija ir SD ir jis dare svarbių žygių iš tikrųjų ja disponuoti. Kaip savo tardyminiuose parodymuose teigè gen. E. Justas, Lietuvos generaliniam komisarui buvo pavaldus SD ir gestapo vadas ${ }^{193}$. Faktiškai taip nebuvo ir dažnai tarp šių dviejų institucijų kildavo nesutarimų kompetencijos bei taktikos klausimais. Ir Lietuvos generalinès srities apygardų komisarams saugumo policija ir SD nebuvo pavaldi ${ }^{194} .1943 \mathrm{~m}$. kovo $25 \mathrm{~d}$. SS reichsfiureris nurodė Ostlando vyresniajam saugumo policijos ir SD vadui, kad visuomet reikia remtis RSHA direktyvomis, o civilinès administracijos ir kariškių pretenzijas atmesti, nes vokiečių saugumo policija turinti specialų A. Hitlerio igaliojimą veikti savarankiškai ir nekontroliuojamai kaip speciali įstaiga (institutionelle Ermächtigung) ${ }^{195}$. Jam savo ruožtu buvo pavaldus H. Himlerio, kaip Reicho komisaro vokiečių rasės klausimais, igaliotinis Lietuvoje, Lietuvos kolonizacijos štabo viršininkas SS šturmbannfiureris dr. Dukartas (Duckart). Jo uždavinys buvo atkeldinti vokiečiu kilmès Lietuvos gyventojus ị Lietuvą. Dauguma jų būdavo įdarbinama ị gestapo ir SD struktūras Lietuvoje.

Nepaisant vienos partinès priklausomybès, tų pačių tikslų siekimo, egzistavo nevieša trintis tarp SS ir policijos vado bei saugumo policijos ir SD vado. Kiekvienas pirmasis vadovas siekė turèti besąlygiškai jam paklusnų antraji. Lietuvos generalinès srities saugumo policijos ir SD vadas buvo ịpareigotas informuoti SS ir policijos vadą apie svarbiausius ịvykius, o taip pat apie gaunamus iš RSHA pagrindinius įsakymus bei aplinkraščius. Bet, matyt, saugumiečiai nelabai paisè ịsipareigojimų (tikriausiai norèta tokiu būdu gauti autonominès veiklos statusą), nes 1944 m. balandi juos pasiekė griežtas RSHA vadovo priminimas apie subordinaciją ${ }^{196}$.

Tą pačią dieną, kai buvo išleistas ir A. Hitlerio dekretas „Dẻl užimtų

193 Lietuviai okupantų vokiečių akimis. Generolo Emilio Justo parodymai. Laisvès kovų archyvas, t. 9, Kaunas, 1993, p. 140.

194 Ten pat, t. 10, Kaunas, 1994, p. 187.

195 K. Rukšèno disertacija „Hitlerininkų politika Lietuvoje 1941 - 1944 metais“, 1970, p. 100. Asmeninis autoriaus archyvas.

196 Befehlsblatt des Chefs der Sicherheitspolizei und des SD, Nr. 15, 04.04.1944. 
rytinių teritorijų policinio saugumo“, vokiečių saugumo policijos ir SD viršininkas R. Haidrichas po suderinimo su gen. ltn. Hermanu Reineke (Hermann Reinecke), kuriam buvo pavesta visų sovietinių karo belaisvių priežiūra, pasirašè operatyvini įsakymą nr. 8, adresuotą vokiečiu saugumo policijos struktūroms Rytuose dẻl „valymų“ sovietinių karo belaisvių stovyklose ${ }^{197}$. Vykdydami ši įsakymą, SD operatyvinių grupių vadai gavo teisę Vermachto užimtose teritorijose tarp karo belaisvių bei civilių gyventojų daryti „nepatikimų elementų“ paiešką bei atranką. Tam prie kiekvienos sovietinių karo belaisviu stovyklos buvo paskirta speciali operatyvine SD komanda, kuri privalèjo iš belaisvių ,atsijoti“" pavojingus Trečiajam Reichui elementus ir priimti tam tikrus sprendimus ${ }^{198}$.

Vokietijos politinė bei karinè vadovybè nuo pat pirmų buvimo Lietuvoje dienų stengèsi panaudoti visą ūkį bei gyventojų resursus karui. Teko laviruoti taikant ir saldainio, ir botago priemones. Pačiame pradiniame karo etape, vaduojant Lietuvą iš sovietų okupacijos, Lietuvos gyventojai parode daug draugiškumo Vokietijos Wehrmachtui ir norą bendradarbiauti, todèl plačiausia savivalda Lietuvos generalinei sričiai buvo suteikta ne be pagrindo. Reicho ministras užimtoms Rytų sritims NSDAP reichsleiteris A. Rosenbergas, suprasdamas, kad vietos gyventojų bendradarbiavimas su vokiečiais savanorišku pagrindu ir kuo savarankiškesne forma duos daugiau naudos, 1942 metų kovo 7 dieną paskelbẻ direktyvas dèl liberalesnio administracijos tvarkymo Lietuvoje, Latvijoje ir Estijoje ir dekretą dèl administracinès savivaldos įvedimo Ostlande. Tuo pačiu buvo įteisinta vietinè savivalda Baltijos šalyse.

Lietuvos teritoriją užėmus vokiečių kariuomenei, lietuvių policija buvo integruota ị vokiečių policijos sudètị. Iš pradžių aukščiausią lietuvių saugumo ir kriminalinès policijos įstaiga buvo Valstybès saugumo departamentas. Vokiečių saugumo policija ir SD griežtai kontroliavo ir savais tikslais tvarkẻ lietuvių saugumo bei kriminalinès policijos ịstaigų darbą. Kaip matyti iš dokumentų, ši kontrolė ypač sustiprèjo nuo 1941 metų liepos pabaigos. Vokiečių saugumo policija ir SD turejjo būti informuojama apie visus suemimus ir sankcionuodavo lietuvių saugumo policijos vykdomus suimtujų atleidimus. Tačiau 1941 metų rugpjūčio mėnesị Vidaus reikalų vadybos Valstybès saugumo departamento padètis buvo pažemintas iki lietuvių saugumo policijos skyriaus (Litauische Abteilung) prie vokiečių

197 Н. С. Алексеев, Злодеяния и возмездие, Москва, 1986, с. 174.

198 В. Краль, Преступления против Европы, Москва, 1968, с. 240. 


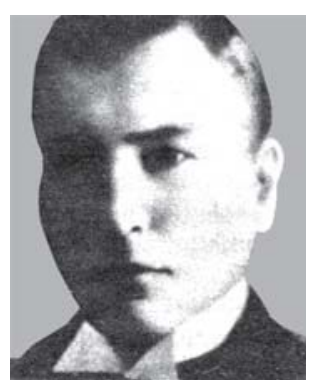

S. Čenkus

saugumo policijos ir SD vado Lietuvos generalinèje srityje (viršininkas Stasys Čenkus ${ }^{199}$ ).

Pagrindine jo funkcija buvo kovoti su sovietiniu bei lenku pogrindžiu ir kriminaliniais nusikaltèliais. Visos komunistų kvotos, kurių neatliko vokiečiu SD, priklausẻ lietuvių saugumo policijai. Rusų autorius S. Čiujevas teigia, kad lietuvių saugumo policijos skyriuje kai kurias vadovaujančias pareigas užėmė SD karininkai - konkrečiai jis pamini SS unteršturmfiurerį Biebl, kuris būdamas vokiečių saugumo policijos ir SD Vilniaus skyriaus IVA 1-ojo poskyrio (ginklai, šaudmenys, kova su partizanais) viršininku, lygiagrečiai ejjo vadovaujančias pareigas lietuvių saugumo policijos Vilniaus apygardos įstaigoje $\mathrm{e}^{200}$.

Vokiečių 814-osios karo lauko komendantūros, pakeitusios 749-ają, komendantas ir karo lauko teismo tarëjas plk. A. Cenpfenigas (Zehnpfennig) 1941 metų liepos 25 dieną Vilniaus miesto ir srities piliečių komiteto pirmininkui doc. Stasiui Žakevičiui raštu pranešè apie Lietuvos teismo įstaigų veiklos suvaržymą. Dokumente rašoma:

1. „Vokietijos piliečiai ir vokiečių tautiečiai Lietuvos teisingumo įstaigoms yra neteismingi.

2. Vokiečių kariuomenès, vokiečių igulos saugumo policijos ir SD veiksmai turi pirmenybę prieš Lietuvos teismo ịstaigų veiksmus.

3. Kariuomenei, igulos saugumo policijai arba SD pareikalavus, suimtieji nusikaltèliai turi būti išduodami.

4. Visi baudžiamieji veiksmai, nukreipti prieš Vokietijos Reichą ar vokiečių kariuomenę (kaip šarlatanavimas, sabotažas, komunistinis veikimas), ar nusikaltimai prieš Valdytojo [Vilniaus miesto ir srities piliečių komiteto Vidaus reikalų valdybos valdytojas K. Kalendra. - P. S.] parédymus turi būti pranešti drauge su nusikaltimo aktais atitinkamai vietos arba lauko komen-

199 Gimė 1901. Prieš karą - Lietuvos policijos valdininkas, pulkininkas. 1933-1939 dirbo Saugumo departamento Marijampolès apygardos viršininku, o 1939-1940 - Vilniaus apygardos viršininku. 1940 rusams okupuojant Lietuvą pasitraukè ị Vokietiją ir dirbo abwehre. Karo metais - Valstybès saugumo departamento direktorius, paskui - Lietuvių saugumo policijos skyriaus prie vokiečių saugumo policijos ir SD vado Lietuvoje viršininkas. 1944 pasitraukè į Vokietiją, o po karo - i JAV. Gyveno Niujorke, dirbo slaptu JAV imigracinès tarnybos ir Federalinio tyrimų biuro tarnautoju.

200 С. Г. Чуев, Спецслужбы III Рейха. Книга II, Санкт-Петербург, 2003, с. 65. 
dantūrai, arba esamam igulos saugumo policijos ir SD skyriui“"201.

Lietuvių policijos batalionai iki 1941 metų liepos 16 dienos tiesiogiai saugojo Kauno kalèjimą, o iki rugsèjo 1 dienos - Vilniaus kalèjimą. Formaliai kalèjimus tvarkė Vidaus reikalų vadybos Kalejimų departamentas. Vèliau kalëjimai perejjo vokiečių saugumo policijos ir SD vado Lietuvoje įstaigos I-o skyriaus žinion, ir jo pavedimu nuo lapkričio 6 dienos visus kalejjimus prižiūrèjo Lietuvos generalinio komisariato Teisės skyriaus valdininkas A. Deinertas. Tačiau jam buvo leista kontroliuoti tik lietuvių administracijos veiksmus. Vokiečiai uždraude be vokiečių saugumo policijos ir SD žinios imti kalinius iš Kauno, Vilniaus ir Šiaulių kalejjimų. Savo pokariniuose prisiminimuose Priverčiamojo darbo valdybos viršininkas Bronius Aušrotas ${ }^{202}$ rašo, kad beveik visuose Lietuvos didesniuose kalejjimuose SD buvo įdarbinusi savo tarnautojus agentus ${ }^{203}$.

Faktišku SD žvalgybos ir kontržvalgybos vadovu Lietuvoje buvo SS hauptšturmfiureris Paulius Miuleris (Paul Müller)204. Visur, kur tik galejjo, jis vokiečių saugumo policijos ir SD vadovybès Lietuvoje vardu verbavo ir rezgè savo agentūrą vietinių gyventojų tarpe ${ }^{205}$. Karo pradžioje vokiečiai verbuojant agentus pirmenybę teikdavo asmenims nukentejjusiems nuo bolševikinio teroro. Agentai privalëjo sekti pasirodančius gyvenvietėse partizanų žvalgus, parašiutininkus, partinius ir komjaunuoliškus aktyvistus. Agentų tinklas buvo jungiamas ị rezidentūras. Rezidentais buvo skiriami aktyvūs lietuviai, jau tarnaujantys vokiškose ịstaigose. Kiekvienas užverbuotas agentas privalėjo pasirašyti pareiškimą pasižadèjimą (Verplichtungserklärung):

„Šiuo îsipareigoju bendradarbiauti su saugumo policija politiniais klausimais. Lygiagrečiai įsipareigoju visas surinktas žinias teikti saugumo polici-

201 Armijų grupès „Centras“ užnugario kariuomenès vado péstininkų gen. Makso fon Šenkendorfo (Maxo von Schenckendorff) raštas 403-iosios apsauginès divizijos vadui, LCVA, f. R-685, ap. 5, b. 1, 1. 2; ibid., f. R-1436, ap. 1, b. 9, 1. 44-45.

202 Gimè 1909-06-25. Prieš karą Lietuvos kariuomenès Generalinio štabo Antrojo skyriaus žvalgybos karininkas. 1940-06-25 pasitraukè ị Vokietiją ir čia buvo ịtrauktas ị karinès žvalgybos darbą. Karo metu - Lietuvos generalinès srities Vidaus reikalų vadybos Priverčiamojo darbo valdybos viršininkas. LNP narys. Nuo 1949 gyveno Floridoje (JAV).

203 B. Aušrotas, Laisvės niekas nežadèjo, Vilnius, 1990, p. 196.

204 Gime 1905-08-26. NSDAP narys (bilieto Nr. 3846146), SS narys (bilieto Nr.133633), nuo 1938-09-11 - SS unteršturmfiureris, iki 1943 - vokiečių saugumo policijos ir SD ịstaigos Lietuvoje III skyriaus (SD) viršininkas.

205 LCVA fonde R-1399 byloje Nr. 102 randame slaptų vokiečių saugumo policijos ir SD agentų pranešimų apie generalinių tarejų įstaigų darbuotojų antinacinę veiklą, apie getų žydų policiją ir kitais klausimais. 
jos vadovybei, kuriai būsiu pavaldus. Bet kuris politinis bendradarbiavimas su kitomis žinybomis man yra griežtai uždraustas. Apie ịvairią informaciją, kuri dẻl su mano bendradarbiavimo su saugumo policija bus man žinoma, privalau išsaugoti paslaptyje, netgi tada, kai jau nebendradarbiausiu su saugumo policija. Atkreiptas mano dėmesys, kad visados privalau vadovautis gautais nurodymais, priešingu atveju galiu susilaukti iš saugumo policijos pusès gan griežtų sankcijų“.

Saugumo policijos ir SD agentūrinio darbo instrukcijoje buvo reikalaujama visų pirma rinkti duomenis apie priešą, jo pajëgų struktūros pažinimas ir ketinimų atskleidimas, vadų nustatymas. Tai galima buvo atlikti integravus savo agentus ị jo gretas, įtartinų asmenų sekimas. Buvo vedama speciali slaptoji SD kartoteka - joje buvo visi duomenys apie ittartus konspiracinejje veikloje asmenis, ịvertinus jų politinį nusiteikimą ir lojalumą. Teisę naudotis šios kartotekos duomenimis turèjo labai nedaug asmenų. Itartini bei paieškomi asmenys buvo registruojami specialiame slaptame leidinyje „Nachrichtendienstblatt“.

Karo metu agentai buvo verbuojami tarp sulaikytų partizanų arba atskleistų tarybinių agentų parašiutininkų. Turejjo SD agentų ir tarp likusių gyvų žydų. Dalis agentų buvo mokomi kontržvalgybinio darbo specifikos. Be to, vokiečių saugumo policijos ir SD padaliniai Lietuvoje turejjo etatinę agentūrą, kuri buvo siunčiama ir integruojama gyvenvietėse, kur ieškojo sovietinių partizanų, parašiutininkų bei atskleisti bolševikinị pogrindị. Rytų frontui grịžus ị Lietuvą, dalis SD agentūros buvo palikta bolševikų okupuotoje Lietuvos teritorijoje vykdyti žvalgybą, atlikti diversijas bei organizuoti pasipriešinimo judejjimą. Šie agentai buvo perduoti Abvero fronto padaliniams.

Gen. mjr. E. Justas, palyginus su vokiečių saugumo policijos pareigūnais, laikèsi liberalesnès politikos Lietuvos gyventojų atžvilgiu, stengèsi sušvelninti saugumo policijos ir SD veiksmus, nors, kaip teigia, su SD ir gestapo vadu nepalaikẻ jokių tarnybinių ryšių. Kauno gestapo viršininkas SS hauptšturmfiureris dr. Heinrichas Schmitcas buvo vienintelis saugumo policijos karininkas, kuris palaikè glaudžius netarnybinius ryšius su komendantūros karininkais. Būtent jis, charakterizuodamas SD tarnybos pareigūnus, pareiške generolui E. Justui, $\mathrm{kad}, \ldots \ldots>$ pasaulyje niekas nesukaupęs savyje tiek daug nepasitikèjimo ir niekas neišauklètas tokia nepasitikejjimo dvasia, kaip SD tarnautojas“206.

Nuo 1942 metų vokiečių saugumo policijos ir SD vado įstaiga Kaune visai Lietuvos generalinei sričiai leido „Kriminalinès policijos žinias“ dviem

206 Lietuviai okupantų vokiečių akimis. Generolo Emilio Justo parodymai. Laisvès kovų archyvas, t. 9, Kaunas, 1993, p. 143. 
kalbomis (redaktorius Petras Pamataitis). Iki tol ši leidinį nuo 1941 metų spalio 1 dienos leido Saugumo departamentas. Ostlande pradètas leisti periodinis informacinis leidinys tik tarnybiniam naudojimui „Befehlsblatt des Chefs der Sicherheitspolizei und des $S D^{\prime \prime}$.

1942 metų rugsėjo 3 dieną vokiečių saugumo policijos ir SD vado Lietuvoje SS štandartenfiurerio K. Jegerio reikalavimu visų lietuvių saugumo kalinių bylos baigus tardymą ir paskyrus bausmę buvo perduodamos tvirtinti jam arba jo įstaigos II F skyriui. Jie visuomet paskirdavo didesnę bausmę ${ }^{207}$. Gestapo sprendimų, vadovaujantis 1936 metų vasario 10 dienos įsakų, neleidžiančių administracinei ir teisminei valdžiai kontroliuoti gestapo veiklą ${ }^{208}$, negalejo pakeisti netgi Vokietijos aukščiausiasis teismas. Lietuvių kriminalinė policija analogišką informaciją privalejjo siųsti vokiečių saugumo policijos ir SD IV skyriui.

1943 metų pabaigoje-1944 metų pradžioje Kaune veikẻ Kriminalinės technikos institutas prie vokiečių saugumo policijos ir SD vado Lietuvoje. Jis buvo ịsikūręs buvusiuose Valstybès saugumo departamento rūmuose (Kaune, Vytauto pr. 67). Institute buvo Rašysenos, Technikos, Biologijos, Fotochemijos ir Chemijos skyriai, kurie atlikdavo rašysenos ir mašinraščio, ginklų, šaudmenų, įsilaužimo žymių bei įrankių, kraujo, spermos, plaukų, dokumentų klastojimo, rašalo, įvairių pėdsakų ir kitokius reikalingus tyrimus ${ }^{209}$.

Su laiku vokiečių saugumo policijos ir SD nepasitikèjimas lietuvių saugumo policija augo ir K. Jegeris ketino visiškai ją likviduoti. Lietuvių saugumo policijos (LSP) skyriaus viršininkas S. Čenkus 1943 metų rugpjūčio 27 dieną parašè argumentuotą tarnybini pranešimą naujajam vokiečiu saugumo policijos ir SD vadui Lietuvoje SS oberfiureriui V. Fuchsui dẻl LSP skyriaus išsaugojimo. Savo rašte jis ịrodè, kad lietuvių saugumas aktyviai kovojo ir ateityje kovos su bolševizmu bei prisidès prie krašto ramybès palaikymo. S. Čenkui pavyko vokiečiams įrodyti lietuvių saugumo policijos naudą palaikant krašte rimtį ir saugumą, ir ji liko veikti iki karo pabaigos ${ }^{210}$.

207 Vokiečių saugumo policijos ir SD vado 1942 m. rugsejjo 4 d. raštas, LCVA, f. R-1399, ap. 1, b. $71,1.16$.

208 Jo 7 paragrafe teigiama, kad niekas jokiu pagrindu negali atšaukti gestapo sprendimų, o teismai neturi teisès nagrinèti tų sprendimų pagrịstumo ir teisètumo.

209 E. Palskys, „Mokslinè teismo ekspertize prieškario Lietuvoje“, Kriminalinė justicija, Vilnius, 1995 , t. 4 , p. 53.

210 Nacionalistų talka hitlerininkams, Vilnius, 1970, p. 47-51. 

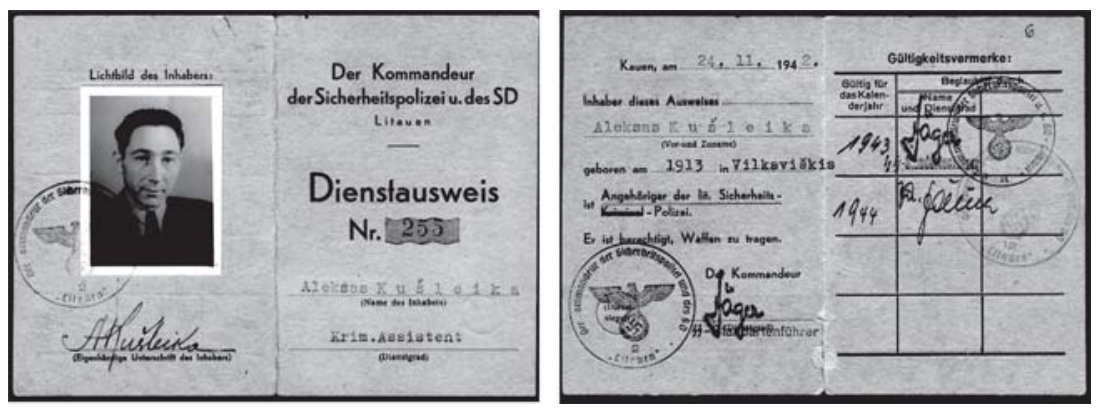

Lietuvių kriminalinès policijos pareigūno kriminalinio asistento Alekso Kušleikos tarnybinis pažymèjimas, pasirašytas vokiečių saugumo policijos ir SD vado Lietuvoje SS standartenfiurerio Karlo Jegerio

Be vokiečių civilinès administracijos išleistų potvarkių, nutarimų, įsakymų ir kitų norminių teisès aktų, saugumo policijos ir SD teisinį veiklos pagrindą sudarè ir kai kurie Trečiojo Reicho baudžiamosios ir civilinès teisès nuostatai, taikyti ne tik Lietuvos teritorijoje apsigyvenusiems vokiečiams, bet ir vietos gyventojams ${ }^{211}$, tai - „Potvarkis dèl vokiečių teismų užimtose Rytų srityse ịsteigimo ir sutvarkymo“ ir „Potvarkis dèl vokiečių baudžiamosios teisès taikymo užimtose Rytų srityse" (abu 1941 metų gruodžio 19 dienos) $)^{212}$. A. Rosenbergas 1942 metų balandžio 27 dieną pasirašė potvarki „Apie vokiečių teisès taikymą Vokietijos piliečiams užimtose Rytų srityse“213, kuriame teigiama, kad remiantis fiurerio 1941 metų liepos 17 dienos įsakymu dẻl naujai užimtų Rytų sričių administravimo šiose srityse nuolat ar laikinai gyvenančių Vokietijos piliečių asmeniniai, šeimyniniai ir paveldejjimo santykiai tvarkomi pagal vokiečių teisę. Vokiečių saugumo policijos ir SD Lietuvos generalinėje srityje kompetencijoje buvo priežiūra, kaip prisilaikoma Vokietijos įstatymų bei kitų teisès aktų reikalavimų.

Vokiečių saugumui ir SD kartu su lietuvių saugumu pavykdavo atskleisti ir likviduoti nemažai sovietinio pogrindžio grupių ir organizacijų. Didèjant lenkų politiniam bei ginkluoto pasipriešinimo aktyvumui, vokiečių saugumo policijos ir SD vado Lietuvoje 1942 metų vasario 6 dienos įsaky-

\footnotetext{
211 Amtsblatt der Generalkomissar in Kauen, 1941, Nr. 1.

212 LCVA, f. R-634, ap. 1, b. 1, 1. 273-276.

213 A. Rosenbergo 1942 m. balandžio 27 d. įsakymo vertimo iš vokiečių kalbos nuorašo kopija, ten pat, 1. 266-269.
} 
mu visoje Lietuvoje buvo suregistruoti lenkų inteligentai ${ }^{214}$. Tų pačių metų pabaigoje vokiečių saugumas pasiekė neblogų rezultatų ir sutriuškino stambią slaptą lenkų organizacija (buvo suimti 74 lenkų kovotojai) ${ }^{215}$. Po dviejų metų, 1944 metų vasario 10-12 dienomis tarp Vilniaus krašto Armijos Krajowos bei vokiečiu saugumo policijos ir SD atstovų vyko derybos. Vokiečiai prašė lenkų pagalbos kovoje su bolševikų partizanais ${ }^{216}$.

Vienas iš svarbiausių Lietuvos generalinès srities vokiečių civilinès administracijos, karinés bei policijos, taip pat SD, vadovybės uždaviniu buvo analizuoti, kovoti ir slopinti besiplečiantị partizaninį judejimą, ypač bolševikinị. Vokiečiai buvo priversti skirti nemažai kovinių pajëgų taip vadinamam „pasyviam karui“" su partizanais: saugoti strateginius karinius objektus, geležinkelio linijas, strateginius tiltus, aerodromus, stambias pramonès įmones ir panašiai. Vermachto sausumos pajègų generalinis štabas bandė gauti A. Hitlerio leidimą panaudoti prieš bolševikų partizanus nuodingas dujas, kad kova prieš nelegalią partizanų veiklą vyktų nelegaliu ginklu, bet fiureris kategoriškai atmete šị pasiūlymą. Pakeliui A. Hitleris uždraudẻ vykdyti tyrimo darbus dèl bakteriologinio ginklo panaudojimo ${ }^{217}$. Bet leido panaudoti rusų karo belaisvius kovoje su partizanais.

SS štandartenfiureris K. Jegeris savo 1942 metų lapkričio 27 dienos raporte savo viršininkui Rygoje teigè, kad iki 1942 metų rudens Vermachto vadovybẻ bei jai pavaldūs daliniai glaudžiai bendradarbiavo su vokiečiu saugumo policija slopinant bolševikų partizanų judejjimą ${ }^{218}$. Nuo pat karo Lietuvoje pradžios šioje srityje ypač aktyviai veikẻ Vokietijos ginkluotujuc pajëgų žvalgyba ir kontržvalgyba - abveras (Abwehr), kuris rinko reikiamą informaciją. Operatyviniai duomenys buvo perduodami apsauginių divizijų, dislokuotų Lietuvoje, vadovybei, kuri imdavosi konkrečių žygių bolševikų židiniams likviduoti. Nuo 1941 metų spalio 25 dienos, kai Vermachto slaptosios karo lauko policijos skyriai, rinkę žinias apie sovietinius žvalgus, partizanus bei diversantus, buvo perduoti vokiečių saugumui, kovoti su sovietinės žvalgybos agentais, partizanais, parašiutininkais, naikinti pogrindžio grupes

\footnotetext{
214 Dokumento vertimo ị lietuvių kalbą nuorašas, LCVA, f. R-1399, ap.1, b.70, 1. 40.

215 Ten pat, b. 61, 1. 22 .

216 M. Foedrowitz, „W poszukiwaniu „modus vivendi“. Kontakty i rozmowy pomiędzy okupantami a okupowanymi dotyczące porozumienia niemiecko-polskiego w czasie II wojny swiatowej“. Mars, 2 tom, Warszawa-Londyn, 1994, s. 176.

${ }^{217}$ D. Irving, Wojna Hitlera, Warszawa, 1996, s. 411.

218 Vokiečių saugumo policijos ir SD vado Lietuvoje raporto nuorašas, LCVA, f. R-614, ap.1, b. $27,1.5$.
} 
visų pirma turèjo vokiečių saugumo policija ir $\mathrm{SD}^{219}$.

Bet laikui bėgant, su aukščiausiosios valdžios sankcija ar be jos, SD igijo vis grèsmingesnę galią, netgi braudamasi ị armijos kompetenciją kaip elgtis su karo belaisviais. Visgi karo priešpaskutiniais metais RSHA peremė iš Vermachto karo belaisvių reikalų tvarkymą. Lietuvoje SD išplètė savo veiklos sritị ir ėmè domètis ne tik politine problematika, bet ir spręsti karinius klausimus, drauge aršiai konkuruodama su karine žvalgyba - abwehru. Kaip teigė savo pokariniuose parodymuose gen. mjr. E. Justas, „, <..> Abvero Kauno skyrius dirbo labai glaudžiai bendradarbiaudamas su SD Kaune $<\ldots .>$. Kiekvieną dieną buvo galima matyti arba Abvero skyriaus karininką prie SD pastato, arba atvirkščiai - SD tarnautoją, įeinantị i Abvero skyrių“220. Bet to nevertinant, kartu tarp Abvero ir SD egzistavo pastovi trintis: ypač abwehras priekaištavo SD pareigūnams, kad jie skuba suimti ir sušaudyti susektą priešo agentą, taip atimdami iš Abvero galimybę išsiaiškinti ryšius bei išnarplioti visą priešo tinklą.

1942 metų sausio mėnesị vokiečiu saugumo policijai ir SD sẻkmingai pavyko sutriuškinti Kaune vieną aktyviausių Lietuvoje grupių, kuriai vadovavo komunistas P. Malinauskas ${ }^{221}$. Be apčiuopiamų nuostolių, iš Maskvos buvo permetamos vis naujos ir naujos diversinès grupès ir jų skaičius augo. Vokietijos vadovybei teko imtis kardinalių priemonių. Gestapo viršininkas H. Miuleris, būdamas lygiagrečiai žuvusio Reicho saugumo policijos ir SD vado SS obergrupenfiurerio R. Haidricho pavaduotoju, 1942 metų birželio 12 dieną pasiraše įsakymą visiems saugumo policijos ir SD bei operatyvinių grupių „A“, „B“, „,C“, „D“ ir „G“ vadams sustiprinti kovą su priešiškais elementais (partizanais, pogrindininkais, parašiutininkais, diversantais) ir taikyti sugriežtintus tardymo metodus ${ }^{222}$. Ypač didelis dèmesys buvo skiriamas sovietinių žvalgų sekimui bei nukenksminimui. Kiekvienas suimtas agentas buvo tardomas vadovaujantis specialiai parengta anketa. Joje pateikti klausimai parodo su kokiu kruopštumu SD pareigūnai sieke išsiaiškinti priešo žvalgybinès grupès, kurios sudètyje buvo pasiųstas agentas, sudètį, gautą užduotị bei ryšius, o taip pat padalinį, kur jị ruošè.

Tvarkos policijos vado Lietuvoje policijos plk. Itn. dr. Valterio Musilio

\footnotetext{
219 Pirčiupio tragedijos kaltininkai, Vilnius, 1975, p. 6.

${ }^{220}$ Lietuviai okupantų vokiečių akimis. Generolo Emilio Justo parodymai. Laisvės kovų archyvas, t. 9, Kaunas, 1993, p. 163.

221 Tegu kalba vokiški popieriai. Švyturys, 1969, Nr. 10, p. 6.

222 А. Зегер, Гестапо-Мюллер, Москва, 1997, с. 118.
} 
(Walter Musil) ${ }^{223}$ nurodymu ${ }^{224}$ visi kovoje su sovietiniais partizanais paimti ginklai privalèjo pereiti vokiečių tvarkos policijos nuosavybėn. Atiduoti ginklus kitoms įstaigoms buvo kategoriškai uždrausta. Partizanų asmeniniai daiktai (išskyrus ginklus) turëjo būti atiduodami artimiausiai SD ịstaigai.

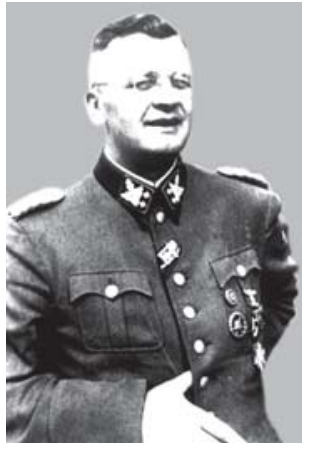

SS igaliotinis partizaniniam judejjimui slopinti SS obergruppenfiureris Erichas fon dem Bach-Celevskis

Iki 1942 metų vasaros ginkluoto pasipriešinimo Rytuose slopinimas buvo Vermachto kompetencijoje. 1942 metų liepos 28 dieną buvo išleistas H. Himlerio ịsakymas, kad bolševikinio partizaninio judejimo slopinimą i t savo rankas perima $S S$ reichsfiureris $^{225}$. A. Hitleris, nepatenkintas saugumo užtikrinimo fronto užnugaryje padètimi, savo 1942 metų rugpjūčio 18 dienos direktyva padalijo atsakomybę už partizaninio judèjimo slopinimą tarp Vermachto ir SS reichsfiurerio. Už praktinị šios direktyvos igyvendinimą tų pačių metų spalio 23 dieną buvo paskirtas „SS ịgaliotinis partizaninio judèjimo slopinimui“" (Der Bevollmächtigte des Reichsführer SS für Bandenbekämpfung) ${ }^{226}$ SS obergrupenfiureris Erichas fon dem Bach-Celevskis (Erich von dem Bach-Zelewski). Ostlande dislokuoti Waffen $S S$, tvarkos policijos, nacionalinès policijos bei saugumo policijos, taip pat EG „A“227, daliniai priklause jam. 1942 metų rudenị kovai prieš sovietinius partizanus Ostlande vadovauti ir telkti bei koordinuoti visas vokiečių bei lietuvių jëgas SS reichsfiurerio $\mathrm{H}$. Himlerio įsakymu buvo pavesta aukštesniajam SS ir policijos vadui Ostlande SS obergrupenfiureriui ir policijos gen. Friedrichui Jeckelnui ${ }^{228}$. Vokiečiams partizaninis pasipriešinimas buvo netikètas. Ostlando, taip pat ir Lietuvos gene-

223 Gimè 1894-06-08, austras, mokslų daktaras. Nuo 1942-11-30 policijos plk. 1tn. 1943 - 1944 tvarkos policijos vadas prie SS ir policijos vado Lietuvos generalineje srityje, o nuo 1943-09 lietuvių savisaugos dalinių inspektorius.

2241944 m. vasario 26 d. nurodymo Nr. 564/44 vertimo ị lietuvių kalbą nuorašas, LCVA, f. R409 , ap. 1 , b. $23,1.61$.

${ }^{225}$ R. Majewski, Waffen SS. Mity i rzeczywistość, Wrocław, Warszawa, Kraków, Gdańsk, 1977, s.139.

2261943 metų birželio 21 dieną šios pareigos buvo pervadintos ị ,antipartizaninių pajègų vadas" (Chef der Bandenkampfverbände).

227 Великая отечественная война, Москва, 1985, с. 680.

228 OKW 1942 m. lapkričio 11 d. direktyvos kovai prieš partizanus vertimo ị lietuvių kalbą nuorašas, LCVA, f. R-680, ap. 2, b. 10, 1. 83. 
ralinès srities SD struktūroms teko jau kovos metu analizuoti partizaninio karo formas, metodus, būdus, nes istorinių analogų panašių i „ „karo iš už kampo" rasti nepavyko.

1942 metų rugpjūtyje Vyriausiosios sausumos kariuomenès vadovybès (Oberkommando des Heeres - OKH) operatyvinio skyriaus nurodymu terminas „partizanas“ buvo pakeistas ị terminą „banditas“. Tuo pačių, antipartizaninius veiksmus imta vadinti „kova su bandomis“. E. fon dem Bach-Celevskio ịsakymu nuo 1942 metų lapkričio 15 dienos kovojusių prieš partizanus Ostlande SD dalinių vadams buvo suteikta teisè patiems spręsti kokių priemonių imtis slopinant ši pasipriešinimąa 229 . Atsižvelgiant ị tai, Ostlando vyresnysis saugumo policijos ir SD vadas SS oberfiureris dr. H. AchamerisPifraderis, 1942 metų lapkričio 18 dieną įsakẻ SD tarnybai suaktyvinti šių bolševikinių grupių žvalgybą, nustatyti dislokacijos vietas ir energingai jas bei jų pagalbininkus naikinti ${ }^{230}$.

1942 metų kovo 13 dieną Biržų apskrityje buvo likviduota LKP(b) CK sekretoriaus I. Meskupo-Adomo vadovaujama viena pirmųjų sovietinių partizanų grupių.

Norėdamas sustiprinti ir suaktyvinti ardomają veiklą vokiečių užimtoje teritorijoje, 1942 metų lapkričio 26 dieną Sovietų Sajungos Valstybès gynybos komitetas nutarẻ sukurti Lietuvos partizaninio judèjimo štabą.

1943 metais bolševikų partizanų grupès suaktyvino savo veiklą Kazėnų miškuose. Pasiremiant SD surinkta informacija, vokiečių SS ir lietuvių policijos pajëgos 1943 metų spalio 19 dieną surengẻ gan sẻkmingą baudžiamają ekspediciją, kurios metu buvo sunaikinta nemažai bolševikų, taip pat „Žalgirio“ brigados komisaras Domas Rocius (Baškys) ${ }^{231}$. Kaip teigia rusų autorius B. Sokolovas, iki 1944 metų sausio 1 dienos Lietuvoje buvo užmuštas 101 bolševikų partizanas bei 4 dingo be žinios (iš jų tik 14 buvo atpažinti) ${ }^{232}$.

1943 metų liepos ménesị Vokietijos vadovas A. Hitleris pripažino: „Valdyti žmones nukariautuose kraštuose, mano nuomone, yra neabejotinai psichologinẻ problema. Vien jẻga valdyti neįmanoma. Tiesa, jèga yra svarbiausia, tačiau ne mažiau svarbus ir truputis psichologijos, kurios reikia ir žvèrių dresiruotojui, jei jis nori būti žvėries viešpats. Jie turi ịtikèti, kad nugalètojai - tai mes“"233.

229 Нюрнбергский процесс, т.3, Москва, 1966, стр. 392.

230 Ostlando saugumo policijos ir SD vado aplinkraščio vertimo ị lietuvių kalbą nuorašas, LCVA, f. R-659, ap.1, b.1, l.133.

231 Hitlerinė okupacija Lietuvoje, Vilnius, 1961, p. 299.

232 Соколов Б.В., Оккупация. Правда и мифы, Москва, 2002, с. 103.

233 G. Sharpas, Pilietine gynyba. Pomilitarinių ginklų sistema, Vilnius, 1992, p. 33. 
1943 metų rugpjūtị vokiečių užimtoje teritorijoje sovietų partizanai pradejjo teroristinị, taip vadinamajị „,bėgių karą“. Tais metais H. Himleris ketino oficialiai paskelbti Ostlandą partizaninio karo sritimi, tačiau tam nepritaré A. Hitleris ${ }^{234}$. 1943 metais kovai su sovietiniu bei lenku partizaniniu judejimu Lietuvoje, buvo įsteigti bei puikiai apginkluoti keli „Schuma“ (Schutzmannschaft der Sicherheitsdienstpolizei) bataliono dydžio daliniai ir priskirti visiškam saugumo policijos ir SD vado Lietuvoje pavaldumui, tačiau apie šiuos dalinius yra labai mažai duomenų.

Kovai su tautiniu lietuvių pasipriešinimu vokiečiu saugumo policijos ir SD struktūroje Kaune buvo ịkurtas specialus poskyris IV A 3, kuriam vadovavo SS hauptšarfiureris H. Rauka (H. Rauca). Dideli rūpestị saugumo policijai ir SD kèlè lietuvių rezistenciniai radijo siųstuvai. Jie žinojo, kad šių siųstuvų laidos yra girdimos užsienyje (Švedijoje) ir jų slopinimui įrengè specialius trukdytuvus Kaune ir Liepojoje ${ }^{235}$. Dèl nelegalių lietuvių spaudos leidinių vokiečiai laikèsi kitos politikos. Apie šią spaudą vokiečių saugumo policija ir SD žinojo, bet niekad rimtai jos nepersekiojo, nes ji skleidẻ antisovietinę propagandą, stengèsi sulaikyti lietuvių tautą nuo aktyvios kovos prieš vokiečius ir todèl jiems buvo netgi naudinga ${ }^{236}$.

Vokiečių saugumo policijos ir SD ataskaitoje buvo rašoma, kad Lietuvos Laisvės kovotojų sajungai (toliau - LLKS) buvo suduotas skaudus smūgis. 1944 metų gegužès 14 dieną gestapas suėmẻ beveik visus LLKS vadovus, taip pat keliasdešimt eilinių jos narių, iš viso apie 60 asmenų ${ }^{237}$. Kitą dieną trokštančiai laisvès ir nepriklausomybès Lietuvai buvo suduotas dar vienas smūgis: gegužès 15 dieną vokiečių saugumo policija ir SD suẻmė Vietinès rinktinès štabą Kaune ir pradèjo represijas prieš Vietinę rinktinę.

Tačiau vokiečių saugumo tarnybų požiūris ị dar taip neseniai persekiotas lietuvių pasipriešinimo organizacijas keitèsi. Vokiečiai suprato, kad lietuviai priešinsis naujai sovietinei okupacijai, o tai buvo jiems naudinga. Netgi pasitraukę iš Lietuvos teritorijos, Vokietijos karinè vadovybe buvo suinteresuota bendradarbiauti su likusiu Lietuvoje antibolševikiniu pogrindžiu. Vokiečių karinè žvalgyba (abwehras) užmezgė ryšius su kai kuriomis pogrindžio organizacijomis. Ypač glaudžius ryšius vokiečiai palaikẻ su Lietuvos laisvės

234 Turonek J., Białoruś pod okupacją niemiecką, Warszawa, 1993, s. 158-159.

235 A. Bubnys, Lietuvių antinacinė rezistencija $1941-1944$ m., Vilnius, 1991, p. 51.

236 Vokiečių saugumo policijos ir SD vado ataskaitos vertimo ị lietuvių kalbą nuorašas, LCVA, f. R-1399, ap. 1, b. 61, 1. 10.

${ }^{237}$ L. Truska, Lietuva bolševikų ir nacių smurto metais, Lietuvos rytas, 199305 08, Nr. 87. 
armija (LLA). O LLA santykiai su vokiečiais rėmėsi ne pavaldumo, bet suinteresuotumo principu. Abi pusès stengèsi panaudoti viena kitą savo naudai. Vokiečių karinẻ vadovybė buvo suinteresuota partizanų veiksmais Raudonosios armijos užnugaryje, kurie atitraukdavo karinius dalinius iš fronto, karinè žvalgyba laukè žvalgybinio pobūdžio informacijos, o LLA norejjo gauti kuo daugiau ginklų iš vokiečių kovai prieš bolševikus. Ir iš tikrųjų, kai kurie Lietuvos laisvès armijos padaliniai gavo iš vokiečių tam tikrą kiekį kokybiškų ginklų. Be to, naujoji Abvero vadovybè (V. Kanaris buvo suimtas), pritariant saugumo policijai ir SD, sutiko karo žvalgybos mokykloje parengti partizaninei veiklai apie šimtą lietuvių savanorių, kurie 1944-ųjų pabaigoje - 1945-uju pradžioje desantu buvo permesti ị Sovietų Sajungos okupuotą Lietuvos teritoriją.

1944 metais Rytų frontui vẻl pradėjus artėti prie Lietuvos sienos, lietuvių savivalda vis labiau neteko valdžios, kurią perėmé vokiečių SS bei saugumo policijos ir SD vadovybè. 1944 metu pabaigoje H. Himleris su savo SS kontroliavo plačiausias Šiaurinès Europos teritorijas, svarbiausius miestus ir uostus, valdè milžiniškus arsenalus naujausių ginklų, slëptuves su auksu ir valiuta. „SS biurokratija“ netgi paskutiniais karo ménesiais dirbo taip, lyg nieko neįvyko. Paaiškinimas paprastas. Nors ir kaip griozdiškai ir biurokratiškai atrode SS struktūra, H. Himleris sugebejo ją puikiai paruošti įvairiom metamorfozėm. „Mano sistema taip atidirbta, kad yra pavyzdys visoms būsimoms valstybẻms, o mano asmeninis aparatas - driežas, kuris visados išsisuks, palikęs medžiotojui uodegą“, - teigé SS reichsfiureris 1944 metų lapkrityje.

Vokiečiai pralaimejjo Antraji pasaulini karą - atèjo nugalètojų keršto nugalėtiesiems valanda. Niurnberge tarptautinis karinis tribunolas pripažino tarp kitų nugalètos Vokietijos organizacijų - SD ir jos trečiają (Hauptamt für SD Taetigkeit im Innland), šeštają (Hauptamt für SD Taetigkeit im Ausland) ir septintają (Amt für Weltanschauliche Forschung) valdybas - nusikalstama organizacija, o jos visus narius bei agentus kartu su vietiniais padaliniais - nusikaltėliais, nepriklausomai, ar buvo SS nariais tik popieriuje, ar ne. Tribunolui buvo pateikta 7000 raštiškų parodymų SD byloje ${ }^{238}$. Tačiau daugybe svarbių SD pareigūnų užėmė aukštus postus Vokietijos Demokratinėje Respubliko$\mathrm{je}^{239}$. Kai kurie autoriai pažymi, kad šiame teismo procese nẻ karto nebuvo

238 T. Cyprian, J. Sawicki, Ludzie i sprawy Norymbergi, Poznan, 1967, s. 95. Kitoje savo veikalo vietoje (s. 149) autoriai nurodo skaičiu 10000.

${ }^{239}$ Simono Wiesenthalio teigimu 450 buvusių nacių užèmè aukštus postus VDR. 


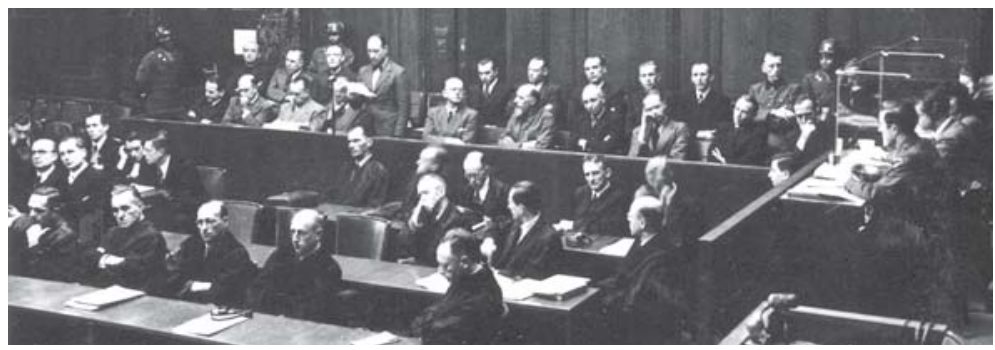

Vaizdas iš operatyvinių grupių narių teismo proceso

paminèta Vyriausioji reicho saugumo valdyba - RSHA ${ }^{240}$.

Pirmą kartą pasaulio visuomenė plačiau sužinojo apie operatyvinių grupių egzistavimą bei nuveiktus karo metu darbus amerikiečių teismo proceso Nr. $9^{241}$ metu Niurnberge, kuris vyko nuo 1947 metų liepos 3 dienos iki 1948 metų balandžio 10 dienos.

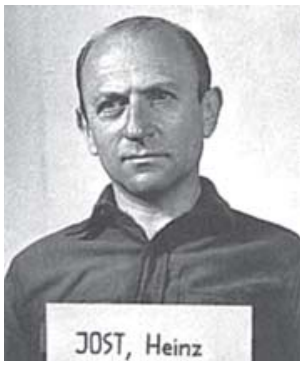

Operatyvinès grupès „A“ vadas SS brigadefiureris ir policijos generolas majoras dr. H. Jostas teisiamujų suole

Ivyko 78 teismo posèdžiai, be teisiamujų apklausta 19 liudininkų. Kaltintojai pateikẻ 253 dokumentus, o gynėjai - 731242. Dar niekad žmonijos istorijoje teisiamųu suole nesėdejo 24 kaltinamieji su aukštuoju išsilavinimu. Jų tarpe buvo aštuoni teisininkai, vienas universiteto profesorius, gydytojas stomatologas, meno istorikas, dvasininkas, operos dainininkas ir garsaus kompozitoriaus Franco Šuberto palikuonis. Dauguma kaltinamųjų turèjo gan aukštą karinị laipsnị: 6 - generolai, 5 - pulkininkai, 6 - papulkininkiai, 4 - majorai, 1 - kapitonas, 1 - vyresnysis leitenantas, 1 - jaunesnysis leitenantas. Kaip matome, kaltinamųų tarpe nebuvo necivilizuotų būtybių, nesugebančių suprasti gyvenimo džiaugsmo subtilybių. Kaltinamoji išvada rèmési

240 Д. Мельников, Л. Черная, Империя смерти, Москва, 1987 с. 193. Tą pati tvirtina ir daugybė kitų rusų bei Vakarų istorikų. Tačiau 1960 metais Maskvoje išleistame septinių tomų Niurnbergo procesų dokumentų rinkinyje (t. VI, s. 121, 141, 161, 473 ir kt.) ir 1966 metais ten pat išleistame trijų tomų Niurnbergo procesų dokumentų rinkinyje (t. 3, s. 338, 461 ir kt.) abreviatūra RSHA minima dešimtis kartu.

241 Iš viso amerikiečiai suorganizavo dvylika teismo procesų.

242 Нюрнбергский процесс, Москва, 1966, том 3, с. 341. 
Tarptautinio Niurnbergo karinio tribunolo medžiaga bei naujai sulaikytų buvusių vokiečių saugumo policijos pareigūnų parodymais.

Kai kuriuos parodymus reikia vertinti skeptiškai, nes jie išgauti neteisètais metodais: A. Eichmano štabo nario SS hauptšturmfiurerio Dieterio Visliceni (Dieter Wisliceny) parodymai apie operatyvines grupes buvo išgauti po to, kai jis pakliuvo ị čekų komunistų rankas ir buvo nežmoniškai tardomas sovietų tardytojų Bratislavos kalejjime 1946 metais. O. Olendorfas pareiške, kad jo parodymai Tarptautiniam Niurnbergo tribunolui 1946 metais apie SD grupių veiklą buvo išgauti taikant žiaurius kankinimus. Be to, kaltintojų dispozicijoje buvo unikali medžiaga: vokiečių saugumo policijos ir SD (tuo pačiu operatyvinių grupių) vadų raportu pagrindu Vyriausiojoje Reicho saugumo valdyboje paruošti „Pranešimai apie įvykius Sovietų Sajungoje“ („Ereignismeldungen UdSSR“). Kaltinamujų tarpe nebuvo nè vieno saugumo policijos ir SD vado iš Lietuvos - K. Jegerio Vakarų šalių kontržvalgyba nesugebejo surasti, V. Fuchsas jau buvo pakartas Jugoslavijos komunistu, o H. J. Biome buvo pamirštas ir tik 1958 metais vokiečių teismo buvo nuteistas. 


\section{Išvados}

Vokietijos politinè vadovybė, organizuodama užimtų Rytų teritorijų administravimą, siekè ịgyvendinti tris funkcionalius uždavinius:

1. Visų pirma, kad gyventojai būtų visiškai paklusnūs, ryžtingai slopinti visus, netgi mažiausius nepaklusnumo bei noro priešintis atvejus.

2. Antra, užtikrinti užimtos teritorijos ekonomikos funkcionavimą vokiečių karinès gamybos labui.

3. Trečia, paversti užimtus kraštus ị neišsenkamą darbo jẻgos vokiečių karinei pramonei rezervuarą, o atskirais atvejais - panaudoti savo karinių dalinių nuostolių kompensavimui bei naujų karinių policijos struktūrų steigimui.

Saugumo policija ir SD buvo viena iš svarbiausių Vokietijos institucijų ir vaidino labai svarbų vaidmeni, igyvendinant Trečiojo Reicho politiką okupuotuose kraštuose. İvedus Lietuvos generalinèje srityje civilinį valdymą, vokiečių Wehrmachtas buvo nustumtas ị antrą barą ir iš tikrujjų valdžia perejjo ị vokiečių SS ir policijos vadovų rankas. Vokiečių policija Lietuvos generalinėje srityje buvo organizuota Trečiojo Reicho pavyzdžiu, tik jos funkcijos buvo platesnès. Vokiečių užimtoje Lietuvoje visa valdžia buvo sukoncentruota SS ir policijos bei saugumo policija ir SD vadų rankose. Jie turejjo nemažai policinès jègos. Saugumo policija ir SD buvo aukščiausioji vokiečiu policinè ir politinè valdžia užimtoje Lietuvos teritorijoje. Vokiečių saugumo policijos struktūrų Lietuvoje tarpe svarbiausią vaidmenị vaidino saugumo tarnyba ir Gestapas. Jų niekuo nesuvaržyta valdžia nuolat augo atiduodant ị jų rankas vis daugiau valdžios. Saugumo policija ir SD Lietuvoje buvo pavaldi RSHA ir nuo jos sprendimų Lietuvoje labai daug kas priklausė.

Iteikta 2005-11-16 


\title{
Résumé
}

\section{L'institution du commandant de la police de sûreté allemande et du service de sûreté (SD) sur la partie générale de Lituanie en 1941-1944}

\author{
Dr. Petras Stankeras
}

L'auteur de cette étude analyse la période de la présence des structures de la police allemande sur la partie générale de Lituanie pendant les années de la deuxième guerre mondiale, raconte en quelques mots l'histoire de la fondation de la police de sûreté allemande et de l'institution de SD, son rôle sur la partie générale de Lituanie en 1941-1944. Cette étude est aussi une première publication historique lituanienne où les schémas d'organisation "A" et "B" de la police de sûreté allemande, de l'administration de SD en Lituanie et des groupes expéditifs de SD sont présentés.

Les institutions spéciales allemandes attribuaient la plus grande importance à la Lituanie parmi les trois Pays Baltes. Principalement, le service de renseignement militaire allemande "Abwehrstelle Königsberg" était très actif en Lituanie. Depuis 1937, presque toutes les divisions de l'Administration générale de sûreté de SS ont commencé à accumuler les informations concernant la Lituanie.

Les Lituaniens ont eu les premiers contacts avec la police de sûreté allemande pendant les premiers jours de la guerre avec l'Union Soviétique. Le 22 juin 1941, le groupe expéditif de SD “A” Einsatzkommando "Tilsit" a entré les régions de l'ouest de la Lituanie. Le matin du 25 juin, le commandant de la police de sûreté allemande et du groupe expéditif de SD est venu à Kaunas, la capitale temporaire de la Lituanie, qui essayait de subordonner les troupes armées lituaniennes, la police de sûreté et publique lituanienne en reconstruction, coordonner leur activité de façon favorable à l'Allemagne. A l'étape initial de la guerre avec l'Union Soviétique, les unités du groupe expéditif de SD "B", appartenant au groupe des armées "Centras", ont entré les régions du sud de la Lituanie. Le 29 juin, l'unité expéditive 3/A (Einsatzkommando 3/A) du groupe expéditif "A" est venu à Kaunas avec son commandant SS standartenfùhrer Karl Jäger, et les Allemands ont pris le contrôle de Kaunas. Le 2 juillet 1941, le groupe expéditif 3/A a pris les fonctions de la police de sûreté en Lituanie et K. Jäger est devenu le premier 
commandant de la police de sûreté et du service de sûreté (SD) sur la partie générale de Lituanie.

Le 1 décembre 1941, l'arrondissement général de SD "Ostland" (Leitabschnitt SD Ostland) a été fondé, qui a compris trois arrondissements de SD (Abschnitt SD) - l'Estonie, la Lettonie et la Lituanie.

Quand le territoire de la Lituanie a été annexé par l'armée allemande, la police lituanienne a été intégrée dans la police allemande. Tout d'abord, l'institution supérieure de la police de sûreté et criminelle lituanienne était le Département national de sûreté. La police de sûreté allemande et SD ont strictement contrôlé le travail des institutions de la police de sûreté et criminelle lituaniennes. Mais au mois d'août 1941, le Département national de sûreté auprès de l'Administration des affaires intérieures est devenu la division de la police de sûreté lituanienne (Litauische Abteilung) auprès de la police de sûreté allemande et du commandant de SD dans la partie générale de la Lituanie. La défiance de la police de sûreté allemande et SD en la police de sûreté lituanienne augmentait et K. Jäger a eu l'intention de la liquider.

L'étude fait une conclusion que la police de sûreté allemande et SD a été une des institutions les plus importantes de l'Allemagne et elle a joué un rôle principale en effectuant la politique du Troisième Reich. Après avoir créé le gouvernement civil sur la partie générale de la Lituanie, le Wehrmacht allemand a pris le rôle secondaire et le pouvoir réel a été dans les mains des commandants de SS et de la police allemande. La police allemande sur la partie générale de la Lituanie a été organisée suivant l'exemple du Troisième Reich, mais ses fonctions ont été plus vastes. Dans la Lituanie, occupée par les Allemands, tout le pouvoir a été concentré dans les mains des commandants de SS, de la police, de la police de sûreté et de SD. C'était une grande force policière. En fait, la police de sûreté et SD a été le pouvoir supérieur, policier et politique, sur le territoire occupée de la Lituanie. Les structures principales en Lituanie ont été le service de sûreté et la Gestapo. Leurs pouvoirs ont été illimités et touchaient presque toutes domaines de la vie quotidienne. La police de sûreté et SD a été subordonné à RSHA et la vie aussi que la mort des habitants dépendaient d'elle. 